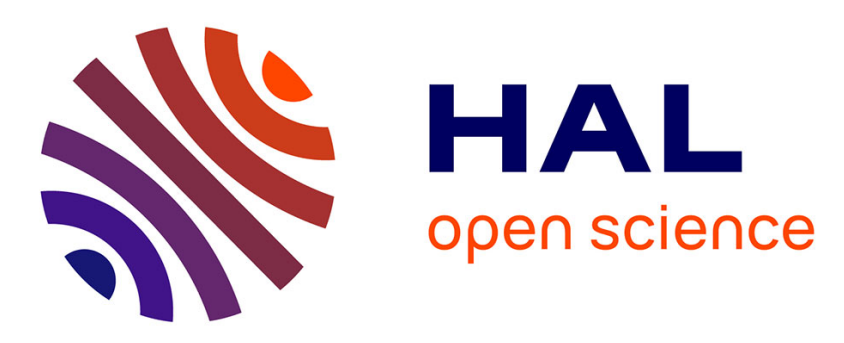

\title{
A HELIXOL-Derived Bisphosphinite Ligand: Synthesis and Application in Gold-Catalyzed Enynes Cycloisomerization
}

Caleb Medena, Francesco Calogero, Quentin Lemoine, Corinne Aubert, Etienne Derat, Louis Fensterbank, Geoffrey Gontard, Omar Abou Khaled, Nicolas Vanthuyne, Jamal Moussa, et al.

\section{To cite this version:}

Caleb Medena, Francesco Calogero, Quentin Lemoine, Corinne Aubert, Etienne Derat, et al.. A HELIXOL-Derived Bisphosphinite Ligand: Synthesis and Application in Gold-Catalyzed Enynes Cycloisomerization. European Journal of Organic Chemistry, 2019, 2019 (11), pp.2129-2137. 10.1002/ejoc.201801722 . hal-02189404

\section{HAL Id: hal-02189404 https: / hal.sorbonne-universite.fr/hal-02189404}

Submitted on 29 Aug 2019

HAL is a multi-disciplinary open access archive for the deposit and dissemination of scientific research documents, whether they are published or not. The documents may come from teaching and research institutions in France or abroad, or from public or private research centers.
L'archive ouverte pluridisciplinaire HAL, est destinée au dépôt et à la diffusion de documents scientifiques de niveau recherche, publiés ou non, émanant des établissements d'enseignement et de recherche français ou étrangers, des laboratoires publics ou privés. 


\title{
A HELIXOL-Derived Bisphosphinite Ligand: Synthesis and Application in Gold-Catalyzed Enynes Cycloisomerization
}

\author{
Caleb Medena, ${ }^{[\mathrm{a}]}$ Francesco Calogero, ${ }^{[\mathrm{aa}]}$ Quentin Lemoine, ${ }^{[\mathrm{a}]}$ Corinne Aubert, ${ }^{[\mathrm{a}]}$ \\ Etienne Derat, ${ }^{[\mathrm{ba}}{ }^{2}$ Louis Fensterbank, ${ }^{\text {[a] }}$ Geoffrey Gontard, ${ }^{\text {[a] }}$ Omar Khaled, ${ }^{[\mathrm{a}]}$ \\ Nicolas Vanthuyne, ${ }^{[b]}$ Jamal Moussa, ${ }^{[a]}$ Cyril Ollivier, ${ }^{[a]}$ Marc Petit, ${ }^{[a]}$ and \\ Marion Barbazanges ${ }^{*[a]}$
}

Abstract: The synthesis, optical resolution through derivatization, characterization, and utilization of a new helical bis(phosphinite gold) complex derived from HELIXOL are described. By using an efficient cobalt catalyst, neither irradiation nor high catalytic loading was required to access the helicene of interest.
The latter was phosphorylated to afford a new chiral ligand that was studied. Especially, treatment with $\mathrm{AuCl}\left(\mathrm{SMe}_{2}\right)$ gives a dinuclear gold complex that was used in cycloisomerization reactions.

\section{Introduction}

Helicenes, aromatic compounds with a helical structure, intrinsically possess interesting chiroptical properties and find applications in various fields such as optics, electronics, supramolecular and organic synthesis. ${ }^{[1]}$ In 2001, Reetz and Sostmann reported the first synthesis of 2,15-bishydroxy[6] helicene (HELIXOL) 1, ${ }^{[2]}$ that could be seen as a helical equivalent of BINOL (Figure 1). The authors report the resolution of both enantiomers of a cyclic precursor through preparative HPLC and used the enantioenriched helix as an efficient fluorescent sensor for chiral amines recognition. As far as we know, in spite of two other synthetic approaches - based on photocyclization and cobaltcatalyzed $[2+2+2]$ cycloaddition under irradiation at high temperature - ${ }^{[3]}$ no other application of HELIXOL has been reported in the literature. In this work, we aimed at synthesizing,

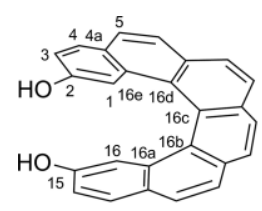

HELIXOL 1

\author{
Previous results \\ Synthesis: photocyclization (irradiation) $2,3 a$ or \\ Co-catalyzed $[2+2+2]$ (irradiation, $\left.140^{\circ} \mathrm{C}\right)^{3 \mathrm{~b}}$ \\ Resolution: chiral HPLC ${ }^{2}$ of a cyclic precursor \\ Application: enantioselective fluorescent sensor ${ }^{2}$ \\ This work \\ Synthesis: Co-catalyzed [2+2+2] $\left(80^{\circ} \mathrm{C}\right)$ \\ Resolution: diastereoisomer synthesis as well as \\ preparative HPLC \\ Application: phosphinite derivatization, gold catalysis
}

Figure 1. HELIXOL 1

[a] Sorbonne Université, Faculté des Sciences et Ingénierie, CNRS, Institut Parisien de Chimie Moléculaire (UMR CNRS 8232),

4 place Jussieu, 75252 Paris Cedex 05, France.

E-mail: marion.barbazanges@sorbonne-universite.fr http://www.ipcm.fr/article679.html?lang=en

[b] Aix Marseille Univ, CNRS, Centrale Marseille, iSm2, Marseille, France

Supporting information and $O R C I D(s)$ from the author(s) for this article are available on the WWW under https://doi.org/10.1002/ejoc.201801722. resolving and functionalizing HELIXOL 1 to get access to a new class of helical-structured phosphinite ligand. The latter will be evaluated on efficient and versatile gold-catalyzed cycloisomerization reactions. ${ }^{[4]}$

\section{Results and Discussion}

\section{Bisphosphinite Ligand Synthesis}

To date, if some Co- or Ni-catalyzed $[2+2+2]$ strategies are reported to access helicenes, they all rely on the use of a large amount of catalyst (from $20 \mathrm{~mol}-\%$ to $50 \mathrm{~mol}-\%$, regarding to the catalytic system used). ${ }^{[5]}$ Moreover, in addition of high catalytic loading, if nickel-catalyzed reaction can be performed at room temperature without UV- or microwave activation, ${ }^{[5 a]}$ use of $\mathrm{CpCo}(\mathrm{CO})_{2}{ }^{[5 \mathrm{a}]}$ or $\mathrm{CpCo}(\mathrm{CO}) \mathrm{dmfu}^{[5 \mathrm{~b}]}$ generally require irradiation (UV and microwaves, respectively) as well as high temperature $\left(>140^{\circ} \mathrm{C}\right)$. There is thus a need for new catalytic systems.

We first tested the published experimental procedure. As reported in the literature, when triyne $\mathbf{2}$ was treated with $\mathrm{CpCo}(\mathrm{CO})_{2}$ (20 mol-\%) and triphenylphosphine (40 mol-\%) in decane at $140{ }^{\circ} \mathrm{C}$ under irradiation, ${ }^{[3 \mathrm{~b}]}$ the desired 2,15-bismethoxy-tetrahydro[6]helicene $( \pm)-3$ was isolated in $78 \%$ yield (Table 1, entry 1). Use of air-stable CpCo(CO)dmfu (15 mol-\%) under microwave irradiation and in the presence of imidazolium salt ${ }^{[5 b]}$ to increase the medium polarity revealed successful as $\mathbf{3}$ was isolated in $93 \%$ yield after 15 min under microwave irradiation (Table 1, entry 2). Decreasing of the catalytic loading to $5 \mathrm{~mol}$-\% led to the desired tetrahydrohelicene $\mathbf{3}$ in $72 \%$ yield due to partial conversion in spite of extended reaction time (Table 1, entry 3).

We thus turned our attention towards low-valent cobalt catalyst $\mathrm{HCo}\left(\mathrm{PMe}_{3}\right)_{4}{ }^{[6]}$ Indeed, in 2013, we disclosed the first use of $\mathrm{HCo}\left(\mathrm{PMe}_{3}\right)_{4}$ in triynes and enediynes cycloaddition reaction. ${ }^{[7]}$ 
Table 1. Co-catalyzed $[2+2+2]$ cycloaddition towards helical pattern $( \pm)-3$. $^{\text {[a] }}$<smiles>C#CCCc1ccc(OC)cc1C#Cc1c(CCC#C)ccc2ccc(OC)cc12</smiles>

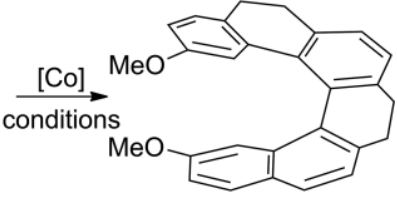

$( \pm)-3$

\begin{tabular}{lllll}
\hline Entries & Catalyst, $\mathrm{x}[\mathrm{mol}-\%]$ & Solvent, Conditions & $\mathrm{T}$ & Yield \\
\hline 1 & $\mathrm{CpCo}(\mathrm{CO})_{2} / \mathrm{PPh}_{3}, 20 / 40$ & decane, $\mathrm{h} v, 1 \mathrm{~h} 30$ & $140{ }^{\circ} \mathrm{C}$ & $78 \%$ \\
2 & $\mathrm{CpCo}(\mathrm{CO}) \mathrm{dmfu}_{1} 15$ & $\mathrm{THF} /$ additive, $\mathrm{MW}, 15 \mathrm{~min}$ & $170{ }^{\circ} \mathrm{C}$ & $93 \%$ \\
3 & $\mathrm{CpCo}(\mathrm{CO}) \mathrm{dmfu}_{1} 5$ & THF/additive, $\mathrm{MW}, 1 \mathrm{~h}$ & $170{ }^{\circ} \mathrm{C}$ & $72 \%$ \\
4 & $\mathrm{HCo}(\mathrm{PMe})_{4}, 5$ & toluene, $24 \mathrm{~h}$ & $80{ }^{\circ} \mathrm{C}$ & $67 \%$ \\
\hline
\end{tabular}

[a] Additive: [1-butyl-2,3-dimethylimidazolium] $\left[\mathrm{BF}_{4}\right]$ (10 mg/mL of solution).

Of particular interest was the ability of this catalyst to react at low loading and without external activation. We thus decided to extend the scope of this well-defined cobalt(I)-catalyst to more challenging helical systems. Indeed, helicity displays an amazing playground to test the new catalytic systems because of the steric hindrance of the designed helix. If no reaction occurred in THF whatever the temperature or the irradiation conditions, we had the pleasure to observe that this catalyst revealed active in toluene in the absence of irradiation. Indeed, when reacting triyne 2 in the presence of $5 \mathrm{~mol}-\% \mathrm{HCo}\left(\mathrm{PMe}_{3}\right)_{4}$ in toluene at $80{ }^{\circ} \mathrm{C},( \pm)-3$ was isolated in $67 \%$ yield (Table 1, entry 4).
Subsequent rearomatization and methoxy cleavage led to HELIXOL ( \pm )-1 in $80 \%$ yield for these two steps. The latter was phosphorylated to afford the corresponding bisphosphinite ( \pm ) $\mathbf{5}$ in $67 \%$ (Scheme 1). ${ }^{[8]}$ Due to bisphosphinite instability, we characterized the corresponding phosphinate $( \pm)-5=0$, obtained by direct phosphorylation with diphenylphosphinic chloride.

2,15-Bis(methoxy)helicene ( \pm )-4 was crystallized through pentane vapor diffusion in dichloromethane (Figure 2, Table 2). $\mathrm{X}$-ray analysis revealed that it has an inner pitch elevation (C1...C16 distance) of 3.051(3) $\AA$ and an oxygen-oxygen distance of 5.289(2) $\AA$. The terminal inner helix torsion angles show an unequal but relatively small opening at $10.0(3)^{\circ}$ and $11.4(3)^{\circ}$. The interplanar angle of the two terminal rings is $50.85(5)^{\circ}$.
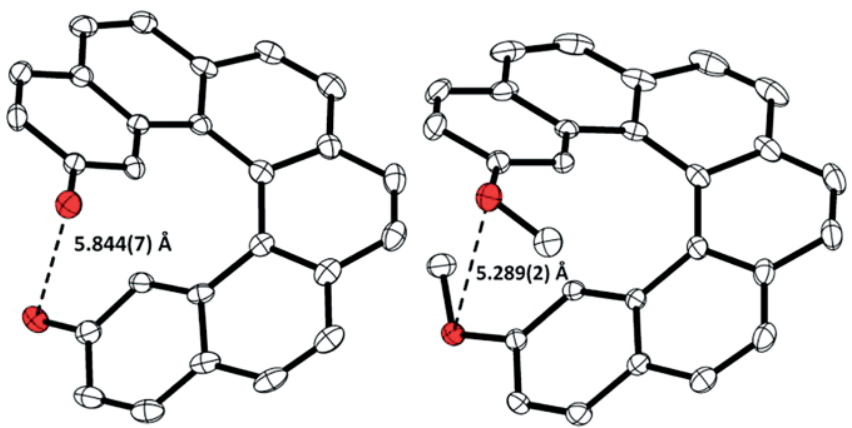

Figure 2. Molecular structures of HELIXOL ( \pm )-1 (left) and bis(methoxy)helicene $( \pm)-\mathbf{4}$ (right) with thermal ellipsoids at $30 \%$ probability.

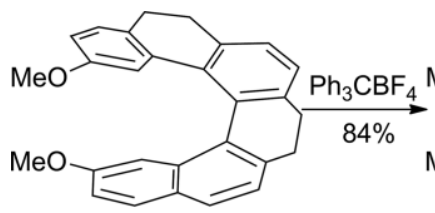

$( \pm)-3$

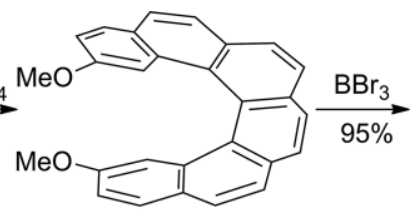

$( \pm)-4$

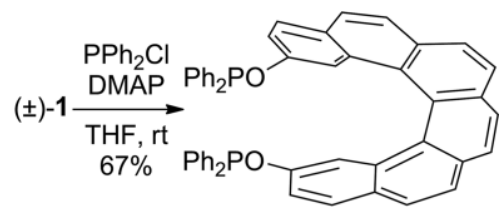

$( \pm)-5$

Scheme 1. Bisphosphinite ( \pm )-5 synthesis.

Table 2. Main crystal data and structure refinement parameters for $( \pm)-\mathbf{1},( \pm)-\mathbf{4},( \pm)-\mathbf{5}=\mathrm{Se},(P)-\mathbf{6}$ and $(M)-\mathbf{6}$.

( \pm$)-1$

Formula

Formula weight

Crystal system

Space group

a

b

c

$\alpha$

$\beta$

$\gamma$

$\mathrm{V}$

Z

Temperature

Wavelength

Theta range

Completeness

Flack parameter

R1 $[I>2 \sigma(l)]$

wR2 (all data)

C 2

$90^{\circ}$

$90^{\circ}$

0.5
$( \pm)-4$

$\mathrm{C}_{26} \mathrm{H}_{16} \mathrm{O}_{2}, \mathrm{H}_{2} \mathrm{O}$

378.40

monoclinic

20.634(3) $\AA$

7.0081(10) Å

$12.6102(15) \AA$

$104.680(8)^{\circ}$

1764.0(4) $\AA^{3}$

Z: $4 \mathbf{Z}^{\prime}: 4$

200(1) K

$1.54178 \AA$

$3.63^{\circ}$ to $67.04^{\circ}$

$97.4 \%$

$6.09 \%$

$15.77 \%$
$\mathrm{C}_{28} \mathrm{H}_{20} \mathrm{O}_{2}$

388.44

monoclinic

P 2 1 /c

7.7453(3) $\AA$

33.3095(12) A

7.6927(3) Å

$90^{\circ}$

$105.133(2)^{\circ}$

$90^{\circ}$

1915.83(13) $\AA^{3}$

Z: 4 Z': 4

200(1) K

$1.54178 \AA$

$5.32^{\circ}$ to $66.59^{\circ}$

$99.8 \%$

$4.56 \%$

$12.69 \%$
$( \pm)-5=\mathrm{Se}$

$\mathrm{C}_{50} \mathrm{H}_{34} \mathrm{O}_{2} \mathrm{P}_{2} \mathrm{Se}_{2}$

886.63

monoclinic

P $2{ }_{1} / \mathrm{n}$

16.4111(3) A

9.2622(2) $\AA$

27.7846(6) $\AA$

$90^{\circ}$

103.094(1)

$90^{\circ}$

4113.53(15) $\AA^{3}$

Z: 4 Z': 4

200(1) K

$0.71073 \AA$

$1.33^{\circ}$ to $26.77^{\circ}$

$99.9 \%$

/

$5.71 \%$

$15.83 \%$
(P)-6

$\mathrm{C}_{50} \mathrm{H}_{34} \mathrm{Au}_{2} \mathrm{Cl}_{2} \mathrm{O}_{2} \mathrm{P}_{2}$

1193.54

monoclinic

P 21

13.4755(3) A

10.1965(3) $\AA$

15.3750(4) Å

$90^{\circ}$

$93.537(2)^{\circ}$

$90^{\circ}$

2108.55(10) $\AA^{3}$

Z: $2 \mathbf{Z}^{\prime}: 2$

200(1) K

$1.54178 \AA$

$4.24^{\circ}$ to $66.66^{\circ}$

$99.6 \%$

$-0.029(6)$

$2.52 \%$

$6.44 \%$
(M)-6

\section{$\mathrm{C}_{50} \mathrm{H}_{34} \mathrm{Au}_{2} \mathrm{Cl}_{2} \mathrm{O}_{2} \mathrm{P}_{2}$}

1193.54

monoclinic

P 21

13.4627(4) $\AA$

10.1946(3) Å

15.3897(4) $\AA$

$90^{\circ}$

$93.383(1)^{\circ}$

$90^{\circ}$

2108.51(10) $\AA^{3}$

Z: 2 Z': 2

200(1) K

$1.54178 \AA$

$2.88^{\circ}$ to $67.09^{\circ}$

$99.0 \%$

$-0.011(17)$

$6.64 \%$

$16.58 \%$ 
Racemic HELIXOL $( \pm)-1$ co-crystallized with a molecule of $\mathrm{H}_{2} \mathrm{O}$ and presents a 3.173(9) $\AA$ inner pitch elevation (C1 ... C16 distance) and a 5.844(7) ^̊ oxygen-oxygen distance. The terminal inner helix torsion angles show an unequal but relatively small opening at $6.4(10)^{\circ}$ and $13.2(10)^{\circ}$. The interplanar angle of the two terminal rings is $60.86(17)^{\circ}$ (Figure 2 ).

\section{Electronic Properties Evaluation}

In order to evaluate its electronic properties as well as the influence of the helical cavity, phosphinite $( \pm)-5$ was converted into the corresponding selenide complex $( \pm)-5=\mathrm{Se} \quad(96 \%)$ (Scheme 2). ${ }^{[9]}$ The latter revealed a ${ }^{1} J_{P \text {-se }}$ coupling constant $(826 \mathrm{~Hz})$ and a chemical shift (85 ppm) identical to the nonhelical phosphinite $\mathbf{7}=\mathrm{Se}^{[10]}$ showing that the helical cavity does not affect the phosphorus environment nor the electronic properties. These phosphinites rank in between the selenatedtriphenylphosphine adduct $\left(\mathrm{Se}=\mathrm{PPh}_{3},{ }^{1} J_{P-S e}=736 \mathrm{~Hz}\right)$ and the selenated-triphenylphosphite one $\left(\mathrm{Se}=\mathrm{P}(\mathrm{OPh})_{3}, \quad{ }^{1} J_{P-S e}=\right.$ $1027 \mathrm{~Hz}){ }^{[11]}$ suggesting an intermediate $\pi$-acidity of this ligand as expected.
$( \pm)$

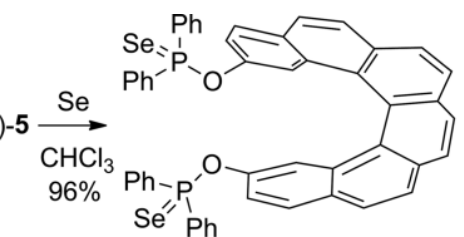

$( \pm)-5=\mathrm{Se}$

$1 \mathrm{~J}(\mathrm{P}-\mathrm{Se})=826 \mathrm{~Hz}$

$\delta=85 \mathrm{ppm}$

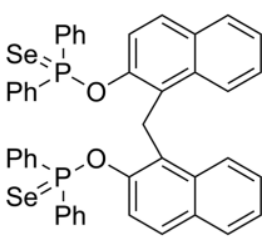

$7=\mathrm{Se}^{10}$

${ }^{1} \mathrm{~J}(\mathrm{P}-\mathrm{Se})=827 \mathrm{~Hz}$ $\delta=86 \mathrm{ppm}$
Scheme 2. Selenated complexes ( $\left.{ }^{31} \mathrm{P} \mathrm{NMR}, \mathrm{CDCl}_{3}\right)$.

The bisphosphiniteselenide complex $( \pm)-\mathbf{5}=$ Se crystallized through pentane vapor diffusion in $\mathrm{CDCl}_{3}$, and presents a 3.075(4) $\AA$ inner pitch elevation (C1 ... C16 distance) and a 5.444(4) $\AA$ oxygen-oxygen distance. The terminal inner helix torsion angles show an unequal opening at $12.8(6)^{\circ}$ and $14.1(6)^{\circ}$, larger than the one observed of HELIXOL 1. The interplanar angle of the two terminal rings is $52.45(12)^{\circ}$ (Figure 3 ).

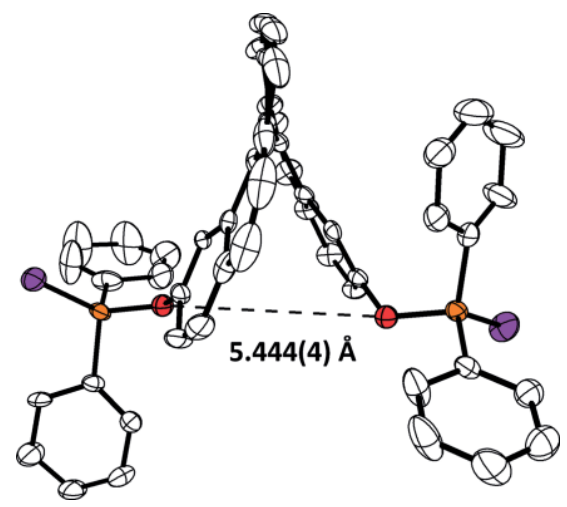

Figure 3. Molecular structure of $( \pm)-\mathbf{5}=$ Se with thermal ellipsoids at $30 \%$ probability.

Subsequent complexation with dimethylsulfide gold chloride led to helical di-gold complex ( \pm )-6 in $98 \%$ yield (Scheme 3). ${ }^{[12]}$
Its ${ }^{31} \mathrm{P}$ NMR spectrum shows a single resonance at $112.3 \mathrm{ppm}$ accounting for the two equivalent phosphinite units. The coordination shift is $4.3 \mathrm{ppm}$.

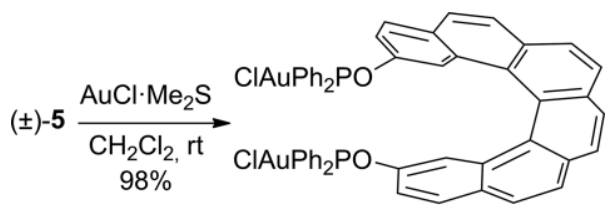

$( \pm)-6$

Scheme 3. Towards bisgold helical complex ( \pm )-6.

\section{Bisphosphinite Ligand Evaluation in Cycloisomerization}

This complex was then evaluated in enyne cycloisomerization reaction. ${ }^{[4]}$ Enyne $\mathbf{8 a}$ was first treated in the presence of 2 mol-\% of helical bisgold complex ( \pm )- 6 (ie 4 mol-\% of gold atom), in the presence of a slight excess of $\mathrm{AgSbF}_{6}$ (5 mol-\%) to insure cationization of the two gold moieties, in dichloromethane as the solvent. Under these conditions, the conversion was fast and total and bicyclo[4.1.0]heptene 9a was isolated in $79 \%$ yield after $20 \mathrm{~min}$ at r.t. (Table 3, entry 1). When $1 \mathrm{~mol}-\%$ of the complex was used, partial conversion was observed and the product was isolated in $50 \%$ yield after $3 \mathrm{~h}$ (entry 2). We then moved towards partial cationization of the dinuclear complex: when 0.5 equiv of silver is used per equiv of gold atom, the reaction revealed sluggish and partial conversion was observed in spite of extended reaction time (entry 3, 30\% yield, $60 \%$ based on recovered starting material). Noteworthy, neither the gold complex nor $\mathrm{AgSbF}_{6}$ alone led to any conversion (entries 4 and 5).

Table 3. Gold-catalysed cycloisomerization.

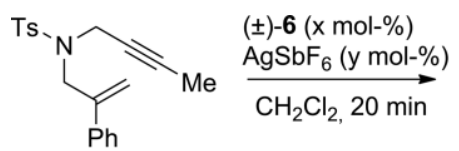

$8 a$

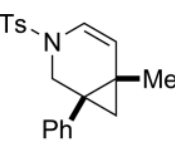

$( \pm)-9 a$

\begin{tabular}{llll}
\hline Entries & $x[\mathrm{~mol}-\%]$ & $y$ [mol-\%] & Yield \\
\hline 1 & 2 & 5 & $79 \%$ \\
2 & 1 & 2 & $50 \%$ \\
3 & 2 & 2 & $30 \%$ \\
4 & 2 & 0 & - \\
5 & 0 & 5 & - \\
\hline
\end{tabular}

Screening of the enyne partner was then achieved in the best reaction conditions ie 2 mol- $\%$ of ( \pm )- 6,5 mol- $\%$ of AgSbF$_{6}$, in $\mathrm{CH}_{2} \mathrm{Cl}_{2}$ at r.t. (Table 3, entry 1). When an o-nosyl electronwithdrawing group was introduced instead of the tosyl one, we had the pleasure to observe similar reactivity. Bicycle $\mathbf{9 b}$ was isolated in $89 \%$ yield (Table 4, entry 2). Switching from a phenyl to a methyl substituent at the internal alkene position led to competition with a 5-exo-dig mechanism: 6-membered ring diene 10c was formed as a by-product (19\%) along with expected product 9c that was isolated in $69 \%$ yield (entry 3 ). Introduction of an oxygen linker revealed trickier and degradation occurred. Decreasing the temperature to $0{ }^{\circ} \mathrm{C}$ allowed isola- 
tion of the bicycle of interest $\mathbf{9 d}$ in $40 \%$ yield (entry 4). Finally, we performed the methoxycyclization of enyne $\mathbf{8 e}$, incorporating a diester linker and a prenyl moiety. After 1 h 30 at r.t. and in the presence of methanol as a nucleophilic co-solvent, we isolated methylenecyclopentane $\mathbf{1 2 e}$ in $65 \%$ yield (entry 5).

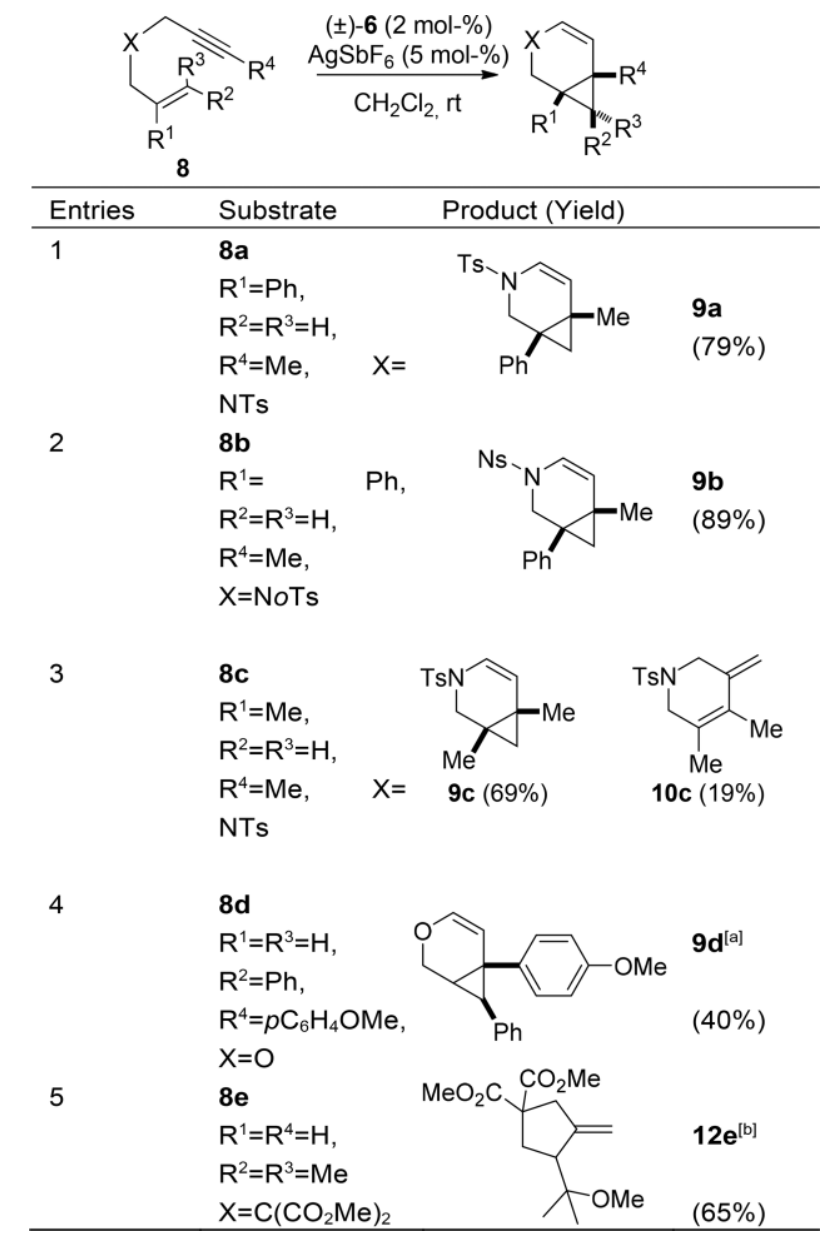

[a] The reaction was performed at $0{ }^{\circ} \mathrm{C}$. [b] $\mathrm{MeOH}$ was used as co-solvent.

\section{Chiral Helical Phosphinite Ligand in Cycloisomerization}

Next move was the evaluation of the impact of helical chirality on this cycloisomerization reaction.

First, we resolved the racemate through diastereoisomers synthesis.

Esterification of the $( \pm)$-1 racemate with $(S, S)$-camphanic acid chloride led to a diastereomeric mixture that was separated by flash chromatography purification. ${ }^{[8]}$ Subsequent saponification $\left(\mathrm{KOH}, \mathrm{THF} / \mathrm{H}_{2} \mathrm{O}\right)$ afforded the enantiomerically pure (ee>99\%) HELIXOLs ( $P$ )-1 and (M)-1 in excellent yields (48\%, 2 steps). It is worthy to note that we also developed a preparative chiral HPLC method that led to an excellent separation of both enantiomers (ee>99\%). ${ }^{[13]}$ Treatment of enantiomerically pure HELIXOLs 1 by chlorodiphenylphoshine in the presence of $\mathrm{N}, \mathrm{N}$ dimethylaminopyridine (DMAP) led to the new helical bisphosphinite ligands $(P)-5(52 \%)$ and $(M)-5$ (77\%) (Scheme 4).

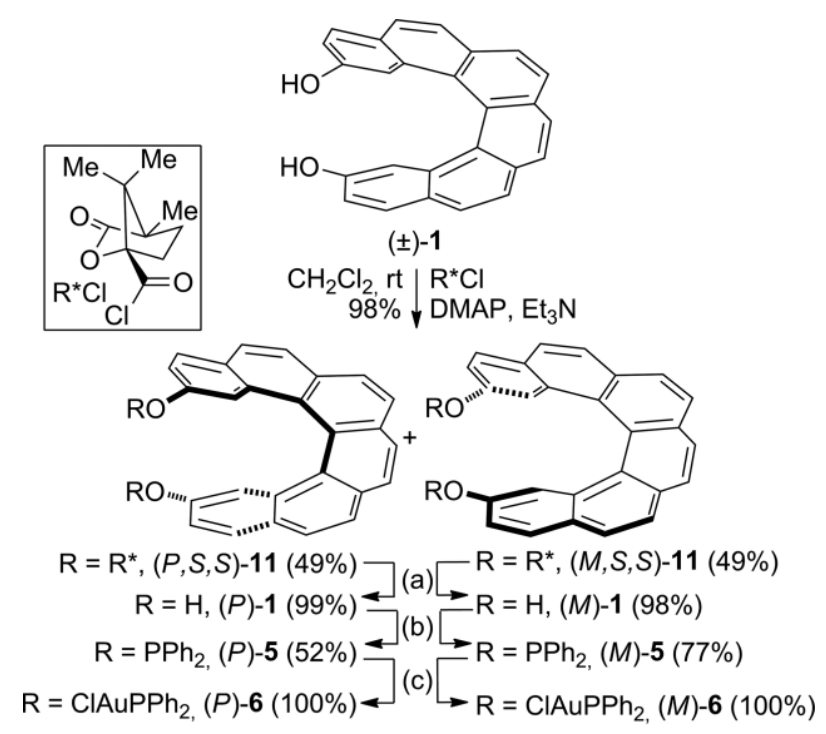

Conditions: (a): $\mathrm{KOH}, \mathrm{THF} / \mathrm{H}_{2} \mathrm{O}$. (b): $\mathrm{PPh}_{2} \mathrm{Cl}$, DMAP, $\mathrm{CH}_{2} \mathrm{Cl}_{2}$. (c): $\mathrm{AuCl} \bullet \mathrm{Me}_{2} \mathrm{~S}, \mathrm{CH}_{2} \mathrm{Cl}_{2}$.

Scheme 4. HELIXOL resolution and derivatization.

Due to bisphosphinite instability, we characterized the corresponding phosphinate $\mathbf{5}=\mathrm{O}$, obtained by direct phosphorylation with diphenylphosphinic chloride. The optical rotation of bisphosphinate $(P)-\mathbf{5}=0$ (respectively $(M)-5=0$ ) was found to be $[\alpha]_{D}^{23}=+3295\left(c \quad 0.042, \mathrm{CH}_{2} \mathrm{Cl}_{2}, 98 \%\right.$ ee) [respectively $[\alpha]_{D}^{23}=$ -3829 (c $0.040, \mathrm{CH}_{2} \mathrm{Cl}_{2}, 96 \%$ ee)]. ${ }^{[14]} \mathrm{CD}$ spectrum of $(P)-5=0$ disclosed a broad negative band around (-)253 nm, and an intense positive band at (+)340 $\mathrm{nm}$ accompanied with a shoulder at $352 \mathrm{~nm}$ (Figure 4).

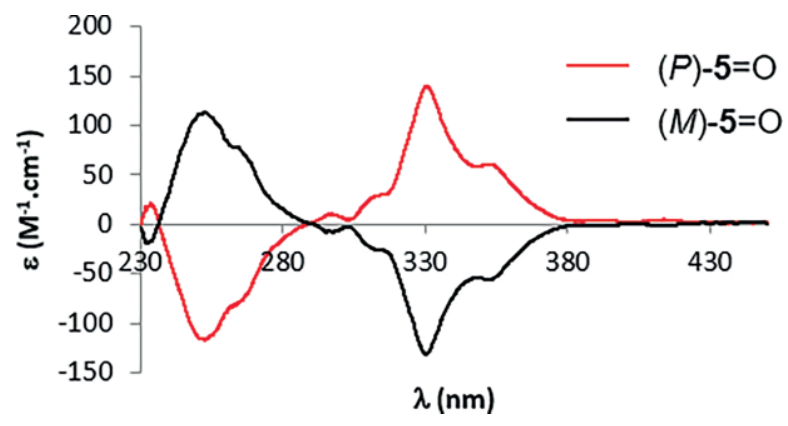

Figure 4. Bisphosphinate $\mathbf{5}=\mathrm{O} C D$.

CD spectrum of $(P)-6$ is very similar to the one of bisphosphinate $(P)-\mathbf{5}=0$. It discloses a broad intense negative band around (-)259 nm, and an intense positive band at (+)334 nm accompanied with a shoulder at $354 \mathrm{~nm}$ (Figure 5, blue line). An optical rotation of $[\alpha]_{D}^{23}=+1244$ (c $0.005, \mathrm{CHCl}_{3}$ ) [respectively $\left.[\alpha]_{D}^{23}=-1250\left(c 0.005, \mathrm{CHCl}_{3}\right)\right]$ was found for bisgold helix $(P)-6$ [respectively $(M)-6]$.

Notably, the CD spectra are in agreement with the absolute configuration determined by X-ray analysis (Table 2 and vide infra Figure 6).

$(P)$-Gold complex [respectively $(M)$-gold complex] was crystallized through pentane vapor diffusion in dichloromethane 


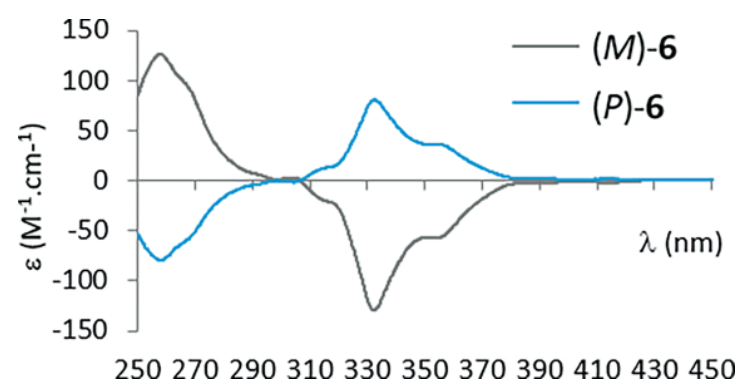

Figure 5. Gold complex 6 CD spectra.
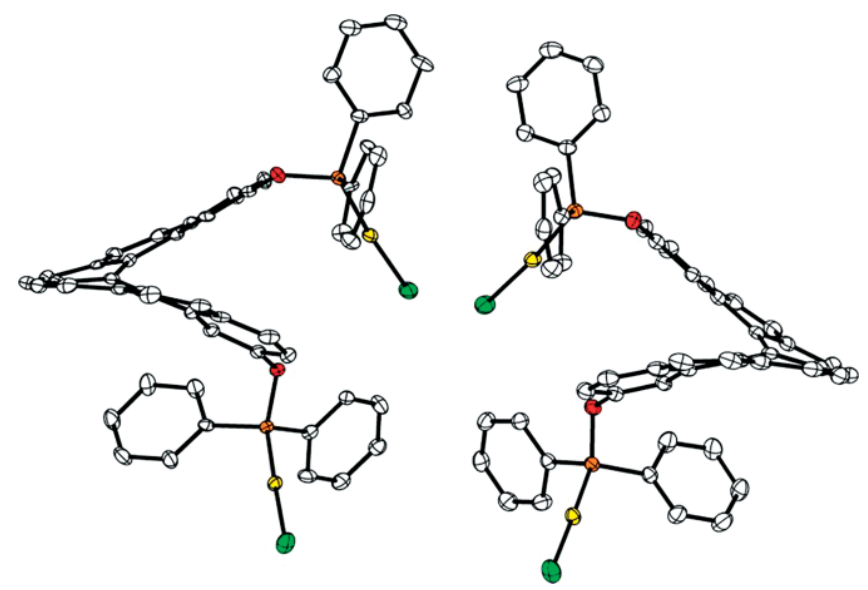

Figure 6. Molecular structures of HELIXOL bisphosphinite gold chloride complexes $(P)-6$ (right) and $(M)-6$ (left) with thermal ellipsoids at $30 \%$ probability.

(Figure 6). X-ray analysis disclosed an inner pitch elevation (C1...C16 distance) of 3.111(10) $\AA$ [respectively 3.094(19) $\AA$ ] and a gold-gold distance of 7.203(1) $\AA$ [respectively 7.210(1) $\AA$ ], precluding any Au...Au interaction. The interplanar angle of the two terminal rings is $55.5(3)^{\circ}$ [respectively $56.1(4)^{\circ}$ ]. Moreover, X-ray crystallography confirmed the absolute configuration attribution through circular dichroïsm (Table 2).

UV-Vis absorption spectra were recorded as diluted solutions in dichloromethane $\left(c \approx 10^{-5} \mathrm{M}\right)$ (Figure 7). As previously, accurate spectra of the free ligand $\mathbf{5}$ could not be obtained due to the high sensitivity of this molecule so the oxidized form $\mathbf{5}=0$ was studied instead.

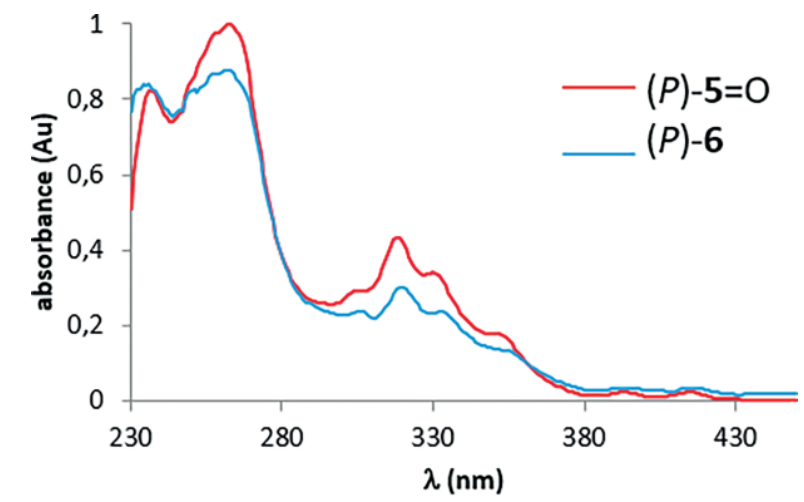

Figure 7. UV/Vis. Absorption for bisphosphinate $(P)-\mathbf{5}=0$ and bisgold $(P)-\mathbf{6}$ in dichloromethane.
The two helixes $(P)-5=0$ and $(P)-\mathbf{6}$ exhibited a similar pattern, with a main envelop of absorption bands in the range of 230-280 $\mathrm{nm}$ with high molar absorption values above $8 \times 10^{4} \mathrm{M}^{-1} \mathrm{~cm}^{-1}$ indicating $\pi-\pi^{*}$ type processes. The spectra all show several transitions in the range of $290-360 \mathrm{~nm}$ with lower molar absorption values $\left(2-4 \times 10^{4} \mathrm{M}^{-1} \mathrm{~cm}^{-1}\right.$ possibly resulting from $\pi-\pi^{*}$ transitions and overlapping charge transfer (oxygen/AuCl moieties to the aromatic rings). We furthermore observe additional tails falling in the near UV area consistent with the presence of charge transfer processes.

Photoluminescence spectra of the oxidized form of the ligand $(P)-\mathbf{5}=0$ and the gold complex $(P)-\mathbf{6}$ were recorded in airequilibrated dichloromethane solutions at $c \approx 10^{-5} \mathrm{M}$ at room temperature (Figure 8). Upon excitation around $380 \mathrm{~nm}$, both compounds show strong emissions in the blue region (410$490 \mathrm{~nm}$ ) with a structured pattern typical of oxygen/AuCl perturbed $\pi-\pi^{*}$ transitions. Such behavior was observed in similar helicene derived compounds. ${ }^{[15]}$

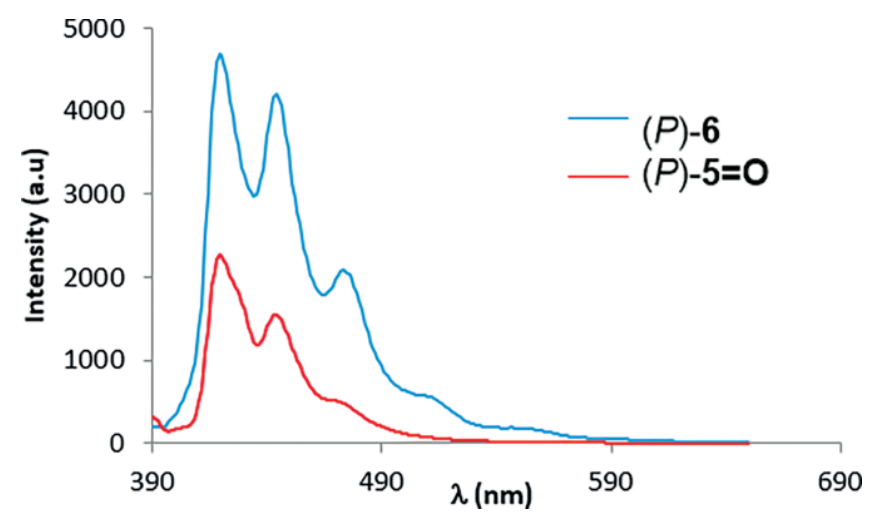

Figure 8. Photoluminescence spectra in dichloromethane solutions $\left(10^{-5} \mathrm{M}\right)$.

By using enantiomerically pure $(P)$-dinuclear gold pre-catalyst $(P)-\mathbf{6}$, under the conditions previously optimized, no enantiomeric excess was obtained (Table 5 , entry 1 ). To improve the ee, the temperature was decreased. When the reaction was run at $0{ }^{\circ} \mathrm{C}$, very low enantioselectivity was observed as the bicyclo[4.1.0]heptene 9a was obtained in $3 \%$ ee in favor of the $(S, S)$ enantiomer (entry 2). ${ }^{[16]}$ Decreasing the temperature to $-25{ }^{\circ} \mathrm{C}$ slowed down the reaction a lot and improved slightly the ee as (S,S)-6 was formed in $11 \%$ ee (35\% yield, entry 3 ). In a similar way, when enyne $\mathbf{8 e}$ was cycloisomerized with $(P)-\mathbf{6}$ and $\mathrm{AgSbF}_{6}$ in the presence of $\mathrm{MeOH}$ as a polar co-solvent at r.t., the desired $(R)$-methylenecyclopentane $12 \mathbf{e}$ was obtained in $6 \%$ ee $(65 \%$ yield, Scheme 5$) .{ }^{[17]}$

Table 5. Cycloisomerization of enyne $\mathbf{8 a}$ in the presence of chiral bisgold complex $(P)-6$.

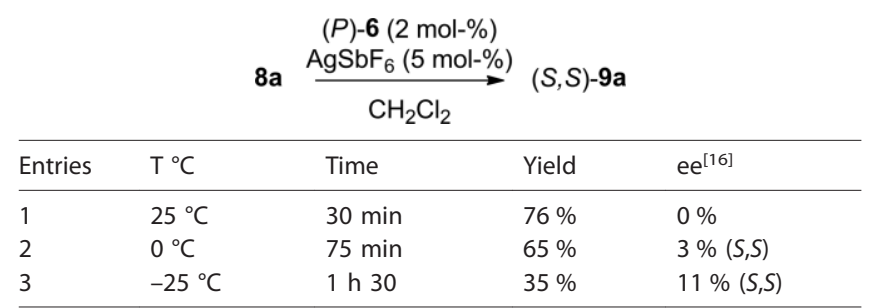




\section{(P)-6 $(2 \mathrm{~mol} \%)$ \\ 8e $\underset{\begin{array}{c}\mathrm{CH}_{2} \mathrm{Cl}_{2} / \mathrm{MeOH} \\ 65 \%\end{array}}{\stackrel{\mathrm{AgSbF}_{6}(5 \mathrm{~mol} \%)}{\longrightarrow}(R)-12 \mathrm{ee}}$}

Scheme 5. Methoxycylization of enyne $\mathbf{8 e}$ in the presence of chiral bisgold complex $(P)-\boldsymbol{6}$.

\section{Conclusion}

We synthesized and characterized an optically enriched new ligand bearing a helical core. Notably, by using $\mathrm{HCo}\left(\mathrm{PMe}_{3}\right)_{4}$ as catalyst for the $[2+2+2]$ cycloaddition key step, neither irradiation nor high catalytic loading was required to access HELIXOL platform. Both enantiomers of HELIXOL 1 could be isolated from diastereomeric derivatization or efficient preparative HPLC separation. The corresponding phosphinites revealed unstable and were trapped as the oxide, the selenated or the gold derivatives. The bis-gold complexes were crystallized and used to perform enynes cycloisomerization. If the racemic version revealed efficient, low enantiomeric excesses were obtained when the optically pure catalysts were tested. The low enantiomeric excesses observed are probably linked to (i) the linear geometry of gold(I) that pointed outwards from the cavity; (ii) the absence of Au...Au interaction due to their distance; (iii) the helicene disubstitution in positions $(2,15)$, so probably too far away from the helical cavity to induce chirality. Further studies will thus focus in bringing the metal center closer to the helical cavity, by switching from $(2,15)$-disubstitution to $(1,16)$-one; or by introducing sterically hindered substitution in the proxima positions. Moving towards square planar metal catalysis such as platinum- or palladium-catalysis could also lead to interesting results in asymmetric catalysis.

\section{Experimental Section}

General: Unless otherwise noted, reactions were carried out in oven-dried glassware under an argon atmosphere. $\mathrm{MeOH}$ was dried overnight over freshly activated molecular sieves $(4 \AA)$, THF and $\mathrm{Et}_{2} \mathrm{O}$ were distilled from sodium-benzophenone. $\mathrm{CH}_{2} \mathrm{Cl}_{2},\left(\mathrm{CH}_{2} \mathrm{Cl}\right)_{2}$, pyridine, $\mathrm{Et}_{3} \mathrm{~N}$, diisopropylamine, toluene, and benzene were distilled from $\mathrm{CaH}_{2}$. Diphenylphosphine chloride was distilled prior to use. Other reagents and chemicals were purchased from commercial sources (Sigma-Aldrich, Alfa Aesar, Fluorochem, Strem Chemicals) and used as received. Flash chromatography was performed on silica gel Merk Geduran or Davisil Grace 40-63 $\mu \mathrm{m}$. Micro-wave assisted $[2+2+2]$-cycloaddition were run in microwave-type reactor, equipped with a stirring bar and sealed with a septum-cap (Biotage, $\mathrm{n}^{\circ}$ 354905). NMR spectra were recorded at room temperature on Bruker AVANCE 600,400 , or 300 spectrometers (BBFO probes), using the residual peak of chloroform (7.26 ppm for ${ }^{1} \mathrm{H}$ NMR and $77.0 \mathrm{ppm}$ for ${ }^{13} \mathrm{C} \mathrm{NMR}$ ), toluene (2.08 ppm for ${ }^{1} \mathrm{H}$ NMR and $20.4 \mathrm{ppm}$ for ${ }^{13} \mathrm{C}$ NMR) dichloromethane (5.32 ppm for ${ }^{1} \mathrm{H}$ NMR and $53.84 \mathrm{ppm}$ for ${ }^{13} \mathrm{C}$ NMR), acetone (2.05 ppm for ${ }^{1} \mathrm{H}$ NMR and $206.26 \mathrm{ppm}$ for ${ }^{13} \mathrm{C}$ NMR) or dimethyl sulfoxide (2.50 ppm for ${ }^{1} \mathrm{H}$ NMR and 39.5 ppm for ${ }^{13} \mathrm{C}$ NMR) as internal standards. Chemicals shifts $(\delta)$ are reported in parts per million (ppm) and coupling constant $(J)$ are given in Hertz $(\mathrm{Hz}) .{ }^{1} \mathrm{H}$ and ${ }^{13} \mathrm{C}$ NMR assignments were based on COSY, HSQC, HMBC experiments. J(C-P) coupling constants were determined based on HSQC and HMBC experiments. Abbreviations used for peak multiplicities are: s (singlet); d (dou- blet); $\mathrm{t}$ (triplet); $\mathrm{m}$ (multiplet, or overlap of non-equivalent resonances); High-resolution mass spectrometry was performed on a Bruker microTOF (ESI) spectrometer; Melting points (m.p.) were recorded with an SMP3 Stuart Scientific melting point apparatus. Infrared (IR) spectra were measured using Tensor 27 (ATR Diamond) Bruker spectrometer. IR data are reported as characteristic bands $\left(\mathrm{cm}^{-1}\right)$ in their maximal intensity. Optical rotations were determined using a JASCO P2000. The circular dichroism was performed on a JASCO J-815 CD spectrometer equipped with a JASCO CDF-426L Peltier thermostat ( $2 \mathrm{~mm}$ quartz cell). Preparative chiral HPLC of HELIXOL was achieved on an Agilent 1260 infinity unit with pump, autosampler, oven, DAD and JASCO CD-2095 circular dichroism detector, controlled by an SRA Instrument software. Enantiomeric excesses of asymmetric catalysis were determined by using chiral HPLC Waters $2487(\lambda=254 \mathrm{~nm})$.

X-ray crystal structure determination: Single crystals were selected, mounted and transferred into a cold nitrogen gas stream. Intensity data were collected with Bruker Kappa-APEX2 systems using microsource $\mathrm{Cu}-\mathrm{K} \alpha(( \pm)-\mathbf{1},( \pm)-\mathbf{4},(P)-6,(M)-6)$ or fine-focus sealed-tube

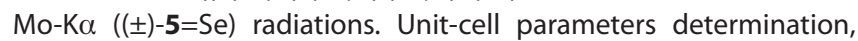
data collection strategy, integration, and absorption correction were carried out with the Bruker APEX2 suite of programs. The structures were solved with SHELXT-2014 and refined anisotropically by fullmatrix least-squares methods with SHELXL-2014 using the WinGX suite $(( \pm)-\mathbf{1},( \pm)-\mathbf{4},(P)-6,(M)-6)$ or Olex2 $(( \pm)-5=S e)$. Compound $( \pm)$ 1 was refined as a perfect inversion twin. Absolute structures of $(P)-\mathbf{6}$ and $(M)-\mathbf{6}$ were determined by anomalous scattering effects analysis and their chemical absolute configurations were then deduced.

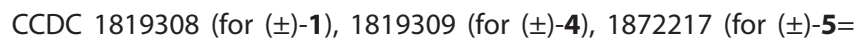
Se), 1819310 for $(P)-6)$ and 1819311 (for $(M)-6)$ contain the supplementary crystallographic data for this paper. These data can be obtained free of charge from The Cambridge Crystallographic Data Centre.

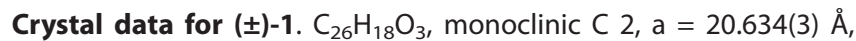
$\mathrm{b}=7.0081(10) \AA, \mathrm{c}=12.6102(15) \AA, \alpha=\gamma=90^{\circ}, \beta=104.680(8)^{\circ}$, $V=1764.0(4) \AA^{3}, Z=4$, colourless prism $0.05 \times 0.05 \times 0.02 \mathrm{~mm}^{3}$, $\mu=0.740 \mathrm{~mm}^{-1}, \min / \max$ transmission $=0.71 / 0.86, \mathrm{~T}=200(1) \mathrm{K}, \lambda=$ $1.54178 \AA, \theta$ range $=3.63^{\circ}$ to $67.04^{\circ}, 5034$ reflections measured, 2698 independent, $R_{\text {int }}=0.0931$, completeness $=0.974,264$ parameters, 1 restraints, Flack $x=0.5$, final R indices $\mathrm{R} 1[I>2 \sigma(l)]=0.0609$ and $w R 2$ (all data) $=0.1577$, GOF on F2 $=0.981$, largest difference peak/hole $=0.20 /-0.26$ e $\AA^{-3}$.

Crystal data for $( \pm)-4 . \mathrm{C}_{28} \mathrm{H}_{20} \mathrm{O}_{2}$, monoclinic $P 21 / c, a=7.7453(3) \AA$, $\mathrm{b}=33.3095(12) \AA, c=7.6927(3) \AA, \alpha=\gamma=90^{\circ}, \beta=105.133(2)^{\circ}, V=$ 1915.83(13) $\AA^{3}, Z=4$, pale yellow prism $0.33 \times 0.11 \times 0.08 \mathrm{~mm}^{3}$, $\mu=0.655 \mathrm{~mm}^{-1}, \mathrm{~min} / \mathrm{max}$ transmission $=0.83 / 0.93, \mathrm{~T}=200(1) \mathrm{K}, \lambda=$ $1.54178 \AA, \theta$ range $=5.32^{\circ}$ to $66.59^{\circ}, 16518$ reflections measured, 3384 independent, $R_{\text {int }}=0.0728$, completeness $=0.998,274$ parameters, 0 restraints, final $R$ indices $R 1[l>2 \sigma(l)]=0.0456$ and wR2 (all data) $=0.1269$, GOF on F2 $=1.055$, largest difference peak/hole $=$ $0.19 /-0.19$ e $\AA^{-3}$.

Crystal data for ( \pm )-5=Se. $\mathrm{C}_{50} \mathrm{H}_{34} \mathrm{O}_{2} \mathrm{P}_{2} \mathrm{Se}_{2}$, monoclinic $\mathrm{P} 2{ }_{1} / \mathrm{n}, \mathrm{a}=$ $16.4111(3) \AA, b=9.2622(2) \AA, c=27.7846(6) \AA, \alpha=\gamma=90^{\circ}, \beta=$ 103.094(1) ${ }^{\circ}, \quad V=4113.53(15) \AA^{3}, Z=4$, colourless plate $0.08 \times 0.19 \times 0.20 \mathrm{~mm}^{3}, \mu=1.916 \mathrm{~mm}^{-1}, \mathrm{~min} / \mathrm{max}$ transmission $=$ $0.75 / 0.91, T=200(1) \mathrm{K}, \lambda=0.71073 \AA, \theta$ range $=1.33^{\circ}$ to $26.77^{\circ}$, 28443 reflections measured, 8769 independent, $R_{\text {int }}=0.0285$, completeness $=0.999,595$ parameters, 76 restraints, final $R$ indices $R 1$ $[I>2 \sigma(l)]=0.0571$ and $w R 2$ (all data) $=0.1583$, GOF on $F^{2}=1.042$, largest difference peak/hole $=1.09 /-0.55$ e $\AA^{-3}$. 
Crystal data for (P)-6. $\mathrm{C}_{50} \mathrm{H}_{34} \mathrm{Au}_{2} \mathrm{Cl}_{2} \mathrm{O}_{2} \mathrm{P}_{2}$, monoclinic $\mathrm{P}$ 21, $\mathrm{a}=13.4755(3) \AA, \mathrm{b}=10.1965(3) \AA, \mathrm{c}=15.3750(4) \AA, \alpha=\gamma=90^{\circ}$, $\beta=93.537(2)^{\circ}, \quad V=2108.55(10) \AA^{3}, Z=2$, yellow prism $0.35 \times 0.05 \times 0.05 \mathrm{~mm}^{3}, \mu=15.097 \mathrm{~mm}^{-1}, \mathrm{~min} / \mathrm{max}$ transmission $=$ $0.20 / 0.61, \mathrm{~T}=200(1) \mathrm{K}, \lambda=1.54178 \AA, \theta$ range $=4.24^{\circ}$ to $66.66^{\circ}$, 25456 reflections measured, 7327 independent, $R_{\text {int }}=0.0426$, completeness $=0.996,523$ parameters, 1 restraint, Flack $x=-0.029(6)$, final R indices R1 $[I>2 \sigma(I)]=0.0252$ and $w R 2$ (all data) $=0.0644$, GOF on F2 $=1.049$, largest difference peak/hole $=0.80 /-0.52$ e $\AA^{-3}$.

Crystal data for (M)-6. $\mathrm{C}_{50} \mathrm{H}_{34} \mathrm{Au}_{2} \mathrm{Cl}_{2} \mathrm{O}_{2} \mathrm{P}_{2}$, monoclinic $\mathrm{P}$ 21, $a=13.4627(4) \AA, b=10.1946(3) \AA, c=15.3897(4) \AA, \alpha=\gamma=90^{\circ}$, $\beta=93.383(1)^{\circ}, \quad V=2108.51(10) \AA^{3}, Z=2$, yellow prism $0.9 \times 0.3 \times 0.1 \mathrm{~mm}^{3}, \mu=15.097 \mathrm{~mm}^{-1}, \mathrm{~min} / \mathrm{max}$ transmission = $0.02 / 0.32, \mathrm{~T}=200(1) \mathrm{K}, \lambda=1.54178 \AA, \theta$ range $=2.88^{\circ}$ to $67.09^{\circ}$, 25983 reflections measured, 7420 independent, $R_{\text {int }}=0.0442$, completeness $=0.990,524$ parameters, 1 restraints, Flack $x=-0.011(17)$, final R indices $R 1[I>2 \sigma(l)]=0.0664$ and $w R 2$ (all data) $=0.1658$, GOF on F2 $=1.041$, largest difference peak/hole $=2.18 /-2.52$ e $\AA^{-3}$.

UV-Vis. absorption and emission properties: Unless otherwise stated, all measurements of the UV-Vis absorption and emission spectra were were performed at $298 \mathrm{~K}$ and in distilled dichloromethane solutions. UV-Vis. spectra were recorded on a JASCO V-670 Spectrometer. Photoluminescence spectra were recorded using a JASCO J-815 CD Spectrometer.

Synthetic procedures: Triyne $\mathbf{2}$ was synthesized through the procedure described in the littérature ${ }^{[3 b]}$ as well as enynes $\mathbf{8} \mathbf{a}^{[18]} \mathbf{8} \mathbf{b},{ }^{[19]}$ $8 c_{,}^{[18]} 8 d_{,}^{[20]} 8 e^{[21]}$

\section{Tetrahydrohelicene $( \pm)-3$ :}

Procedure for Table 1, entry $1:^{[3 \mathrm{~b}]}$ In a Schlenk flask, to a solution of triyne 2 (524 mg, $1.33 \mathrm{mmol}, 1$ equiv) and triphenylphosphine (139 mg, $532 \mu \mathrm{mol}, 0.4$ equiv) in degassed $n$-decane $(0.05 \mathrm{M}, 33 \mathrm{~mL}$ ) at $90{ }^{\circ} \mathrm{C}$, was added $\mathrm{CpCo}(\mathrm{CO})_{2}(36 \mu \mathrm{L}, 265 \mu \mathrm{mol}, 0.2$ equiv). The mixture was stirred at $140{ }^{\circ} \mathrm{C}$ for $2 \mathrm{~h}$ under concomitant irradiation with a halogen lamp. The solvent was removed under reduced pressure and the residue was purified by flash chromatography on silica gel (petroleum ether/ $\mathrm{Et}_{2} \mathrm{O}, 98 / 2$ ), to yield tetrahydrohelicene $( \pm)$-3 (411 mg, $78 \%$ ) as a yellow solid. Characterization data are in agreement with those previously reported in the literature. ${ }^{[3 \mathrm{~b}]}$

Procedure for Table 1, entry 2: In a microwave reactor, to a solution of triyne 2 (31.3 $\mathrm{mg}, 0.080 \mathrm{mmol}, 1$ equiv) and imidazolium salt $(50 \mathrm{mg})$ in THF $(5 \mathrm{~mL})$ was added $\mathrm{CpCo}(\mathrm{CO}) \mathrm{dmfu}(3.5 \mathrm{mg}, 12 \mu \mathrm{mol}$, 0.15 equiv) and the vial was sealed. After degassing by argon bubbling $(10 \mathrm{~min})$ through the septum, the mixture was heated at $170{ }^{\circ} \mathrm{C}$ under microwave irradiation. After $15 \mathrm{~min}$, the vial was cooled to room temperature, and the reaction mixture concentrated under reduced pressure. The residue was purified by flash chromatography on silica gel (petroleum ether/ $\mathrm{Et}_{2} \mathrm{O}, 98 / 2$ ), to yield tetrahydrohelicene $( \pm)-3$ (29 mg, $93 \%)$ as a yellow solid.

Procedure for Table 1, entry 3: In a microwave reactor, to a solution of triyne 2 (31.3 mg, $0.080 \mathrm{mmol}, 1$ equiv) and imidazolium salt $(50 \mathrm{mg})$ in THF $(5 \mathrm{~mL})$ was added $\mathrm{CpCo}(\mathrm{CO}) \mathrm{dmfu}(1.2 \mathrm{mg}, 4.0 \mu \mathrm{mol}$, 0.05 equiv) and the vial was scelled. After degazing by argon bubbling (10 $\mathrm{min})$ through the septum, the mixture was heated at $170^{\circ} \mathrm{C}$ under microwave irradiation. After $1 \mathrm{~h}$, the vial was cooled to room temperature and the reaction mixture concentrated under reduced pressure. The residue was purified by flash chromatography on silica gel (petroleum ether/Et ${ }_{2} \mathrm{O}, 98 / 2$ ), to yield tetrahydrohelicene $( \pm)-3$ (22.4 mg, $72 \%$ ) as a yellow solid.

Procedure for Table 1, entry 4: To a solution of $\mathrm{HCo}\left(\mathrm{PMe}_{3}\right)_{4}(2.7 \mathrm{mg}$, $0.01 \mathrm{mmol}, 0.05$ equiv) in toluene $(0.5 \mathrm{~mL})$ was added a solution of triyne 2 (50 mg, $0.13 \mathrm{mmol}, 1$ equiv) in toluene $(2.0 \mathrm{~mL})$. After $18 \mathrm{~h}$ at $80^{\circ} \mathrm{C}$, the reaction mixture was concentrated under reduced pressure. Purification by flash chromatography on silica gel gave (土)-3 (34 mg, $67 \%)$ as a yellow solid.

Dimethoxyhelicene $( \pm)-4$ : To a solution of tetrahydrohelicene $( \pm)$ 3 (389 mg, 990 umol, 1 equiv) in 1,2-dichloroethane $(25 \mathrm{~mL}$ ) was added $\mathrm{Ph}_{3} \mathrm{CBF}_{4}$ (980 mg, $2.97 \mathrm{mmol}, 3$ equiv). The mixture was stirred at $80{ }^{\circ} \mathrm{C}$ for $18 \mathrm{~h}$. Evaporation of the solvent and purification by flash chromatography on silica gel (petroleum ether/ $/ \mathrm{Et}_{2} \mathrm{O}, 95: 5$ ) afforded dimethoxyhelicene $( \pm)-\mathbf{4}(323 \mathrm{mg}, 84 \%)$ as a yellow solid. The latter was crystallized through pentane vapor diffusion in dichloromethane. Characterization data are in agreement with those previously reported in the literature. ${ }^{[3 b]}$

HELIXOL ( \pm )-1: To a solution of dimethoxyhelicene $( \pm)-4$ (312 mg, $803 \mu \mathrm{mol}, 1$ equiv) in dichloromethane $(27 \mathrm{~mL})$ at $0{ }^{\circ} \mathrm{C}$ was slowly added $\mathrm{BBr}_{3}\left(1 \mathrm{M}\right.$ in $\mathrm{CH}_{2} \mathrm{Cl}_{2}, 8.03 \mathrm{~mL}, 8.03 \mathrm{mmol}, 10$ equiv). After $18 \mathrm{~h}$ at r.t., the reaction mixture was quenched with water, and the separated aqueous layer was extracted with dichloromethane. The combined organic extracts were dried with anhydrous $\mathrm{MgSO}_{4}$ and concentrated under reducer pressure. The residue was purified by chromatography on silica gel (petroleum ether/EtOAc, 80:20) to afford the HELIXOL ( \pm )-1 (275 mg, $95 \%$ ) as a yellow solid. The latter was crystallized by slow evaporation of $\mathrm{CD}_{2} \mathrm{Cl}_{2}$. Characterization data are in agreement with those previously reported in the literature. ${ }^{[3 b]}$

\section{HELIXOL Optical Resolution:}

$(P, S, S)-2,15$-bis $\left\{4^{\prime}, 7^{\prime}, 7^{\prime}\right.$-trimethyl-3'-oxo-2'-oxabicyclo[2.2.1] heptane-1'-carbonyloxy $\}[6]$ helicene $((P, S, S)-11)$ and $(M, S, S)$ 2,15-bis $\left\{4^{\prime}, 7^{\prime}, 7^{\prime}\right.$-trimethyl-3'-oxo-2'-oxabicyclo[2.2.1] heptane$\mathbf{1}^{\prime}$-carbonyloxy\}[6]helicene ((M,S,S)-11): To a solution of $( \pm)-1$ (364 mg, $1.01 \mathrm{mmol}, 1$ equiv), DMAP (123 mg, $1.01 \mathrm{mmol}, 1$ equiv) and $\mathrm{Et}_{3} \mathrm{~N}(0.56 \mathrm{~mL}, 4.04 \mathrm{mmol}, 4$ equiv) in dichloromethane $(28 \mathrm{~mL})$ at $0{ }^{\circ} \mathrm{C}$ was added a solution of (1S)-(-)-camphanic acid chloride (656 mg, $3.03 \mathrm{mmol}, 3$ equiv) in dichloromethane $(7 \mathrm{~mL})$. After $18 \mathrm{~h}$ at r.t., the solvent was evaporated under reducer pressure and the residue purified by flash chromatography on silica gel (petroleum ether/EtOAc: 80:20 to 70:30) to afford $(P, S, S)-\mathbf{1 1}$ (early eluting fraction) as a brown solid (349 mg, 49\%) and (M,S,S)-11 (late eluting fraction) as a brown solid (350 $\mathrm{mg}, 49 \%$ ).

$(P, S, S)-11:[\alpha]_{D}^{23}=+1808\left(c=0.005, \mathrm{CHCl}_{3}\right) ;$ HRMS (ESI) $\mathrm{m} / \mathrm{z}$ calcd. for $\mathrm{C}_{46} \mathrm{H}_{40} \mathrm{O}_{8}\left([\mathrm{M}+\mathrm{Na}]^{+}\right): 743.2615$, found 743.2625. IR (neat): $v\left(\mathrm{~cm}^{-1}\right)$ $=3045,2968,2934,2876,1780,1766,1309,1256,1218,1168,1106$, 1046, 852, 758; $R_{\mathrm{f}}=0.51$ (petroleum ether/EtOAc: 60:40); ${ }^{1} \mathrm{H} \mathrm{NMR}$ $\left(400 \mathrm{MHz}, \mathrm{CDCl}_{3}\right) \delta 0.85(\mathrm{~s}, 6 \mathrm{H}), 0.90(\mathrm{~s}, 6 \mathrm{H}), 1.13(\mathrm{~s}, 6 \mathrm{H}), 1.67$ (ddd, $J=13.2,8.8,4.2 \mathrm{~Hz}, 2 \mathrm{H}), 1.85-1.98(\mathrm{~m}, 4 \mathrm{H}), 2.37$ (ddd, $J=12.6,10.2$, $4.2 \mathrm{~Hz}, 2 \mathrm{H}), 7.11(\mathrm{dd}, J=8.7,2.4 \mathrm{~Hz}, 2 \mathrm{H}), 7.35(\mathrm{~d}, J=2.4 \mathrm{~Hz}, 2 \mathrm{H})$, $7.82(\mathrm{~d}, J=8.7 \mathrm{~Hz}, 2 \mathrm{H}), 7.85(\mathrm{~d}, J=8.5 \mathrm{~Hz}, 2 \mathrm{H}), 7.92(\mathrm{~d}, J=8.5 \mathrm{~Hz}$, $2 \mathrm{H}), 7.98(\mathrm{~d}, J=8.2 \mathrm{~Hz}, 2 \mathrm{H}), 8.02(\mathrm{~d}, J=8.2 \mathrm{~Hz}, 2 \mathrm{H}) .{ }^{13} \mathrm{C} \mathrm{NMR}$ $\left(100 \mathrm{MHz}, \mathrm{CDCl}_{3}\right) \delta 9.7\left(2 \mathrm{CH}_{3}\right), 16.7\left(2 \mathrm{CH}_{3}\right), 16.8\left(2 \mathrm{CH}_{3}\right), 28.8\left(2 \mathrm{CH}_{2}\right)$, $30.3\left(2 \mathrm{CH}_{2}\right), 54.4(2 \mathrm{C}), 54.7(2 \mathrm{C}), 90.6(2 \mathrm{C}), 118.8(2 \mathrm{CH}), 120.2(2 \mathrm{CH})$, $123.8(\mathrm{C}), 126.5(2 \mathrm{CH}), 126.9(2 \mathrm{C}), 127.2(2 \mathrm{CH}), 127.4(2 \mathrm{CH}), 127.6$ $(2 \mathrm{CH}), 129.0(2 \mathrm{CH}), 129.9(2 \mathrm{C}), 130.4(2 \mathrm{C}), 131.8(2 \mathrm{C}), 133.2(\mathrm{C}), 147.5$ (2C), $165.2(2 \mathrm{C}), 177.8(2 \mathrm{C})$.

$(M, S, S)-11:[\alpha]_{\mathrm{D}}^{23}=-1802\left(c=0.005, \mathrm{CHCl}_{3}\right) ;$ HRMS (ESI) $\mathrm{m} / \mathrm{z}$ calcd. for $\mathrm{C}_{46} \mathrm{H}_{40} \mathrm{O}_{8}\left([\mathrm{M}+\mathrm{Na}]^{+}\right)$: 743.2615 , found $743.2625 ; R_{\mathrm{f}}=0.45$ (petroleum ether/EtOAc: 60:40); ${ }^{1} \mathrm{H} \mathrm{NMR}\left(400 \mathrm{MHz}, \mathrm{CDCl}_{3}\right) \delta 0.77(\mathrm{~s}, 6 \mathrm{H})$, $0.95(\mathrm{~s}, 6 \mathrm{H}), 1.13(\mathrm{~s}, 6 \mathrm{H}), 1.70(\mathrm{ddd}, J=13.2,9.2,4.2 \mathrm{~Hz}, 2 \mathrm{H}), 2.05-$ $1.89(\mathrm{~m}, 4 \mathrm{H}), 2.37(\mathrm{ddd}, J=13.2,4.2,2.6 \mathrm{~Hz}, 2 \mathrm{H}), 7.09(\mathrm{dd}, J=8.7$, $2.3 \mathrm{~Hz}, 2 \mathrm{H}), 7.34(\mathrm{~d}, J=2.3 \mathrm{~Hz}, 2 \mathrm{H}), 7.81(\mathrm{~d}, J=8.7 \mathrm{~Hz}, 2 \mathrm{H}), 7.85$ (d, $J=8.6 \mathrm{~Hz}, 2 \mathrm{H}), 7.93(\mathrm{~d}, J=8.6 \mathrm{~Hz}, 2 \mathrm{H}), 7.97(\mathrm{~d}, J=8.2 \mathrm{~Hz}, 2 \mathrm{H}), 8.02$ $(\mathrm{d}, J=8.2 \mathrm{~Hz}, 2 \mathrm{H}) ;{ }^{13} \mathrm{C} \mathrm{NMR}\left(100 \mathrm{MHz}, \mathrm{CDCl}_{3}\right) \delta 9.6\left(2 \mathrm{CH}_{3}\right), 16.7$ 
$\left(2 \mathrm{CH}_{3}\right), 16.9\left(2 \mathrm{CH}_{3}\right), 28.9\left(2 \mathrm{CH}_{2}\right), 30.5\left(2 \mathrm{CH}_{2}\right), 54.3(2 \mathrm{C}), 54.7(2 \mathrm{C})$, $90.6(2 \mathrm{C}), 119.0(2 \mathrm{CH}), 120.2(2 \mathrm{CH}), 123.7(\mathrm{C}), 126.6(2 \mathrm{CH}), 126.9(2 \mathrm{C})$, $127.2(2 \mathrm{CH}), 127.5(2 \mathrm{CH}), 127.6(2 \mathrm{CH}), 129.0(2 \mathrm{CH}), 129.9(2 \mathrm{C}), 130.5$ (2C), $131.8(2 \mathrm{C}), 133.25(\mathrm{C}), 147.3(2 \mathrm{C}), 165.3(2 \mathrm{C}), 177.6(2 \mathrm{C})$.

To a solution of (P,S,S)-11 (299 mg, $0.41 \mathrm{mmol}, 1$ equiv) in THF $(20 \mathrm{~mL})$ at $0{ }^{\circ} \mathrm{C}$ was added a solution of $\mathrm{KOH}(233 \mathrm{mg}, 4.15 \mathrm{mmol}$, 10 equiv) in $\mathrm{H}_{2} \mathrm{O}(20 \mathrm{~mL})$. After $2 \mathrm{~h}$ at r.t., the reaction mixture was quenched with acetic acid $(1 \mathrm{~mL})$ and diluted with $\mathrm{CH}_{2} \mathrm{Cl}_{2}$. The separated aqueous phase was extracted with $\mathrm{CH}_{2} \mathrm{Cl}_{2}$, and the combined organic extracts were washed with a saturated aqueous solution of $\mathrm{NaHCO}_{3}$, then dried with $\mathrm{MgSO}_{4}$, filtered and concentrated under reduced pressure. The residue was purified by flash chromatography on silica gel (petroleum ether/EtOAc, 80:20) to give (P)-1 as a yellow solid (148 $\mathrm{mg}, 99 \%)$.

Similarly, HELIXOL (M)-1 was obtained from $(M, S, S)-11$ (0.20 g, $0.28 \mathrm{mmol})$ in THF (14 mL) and $\mathrm{KOH}(0.16 \mathrm{~g}, 2.8 \mathrm{mmol}, 10$ equiv) in water $(14 \mathrm{~mL})$. Purification by flash chromatography on silica gel (petroleum ether/EtOAc, 80:20) led to $(M)-\mathbf{1}(99 \mathrm{mg}, 98 \%$ ) as a yellow solid.

Chiral HPLC analysis were realized on Column ChiralPak IA, hexanes/ iPrOH: 67:33 flow rate $1 \mathrm{~mL} / \mathrm{min}, \lambda=254 \mathrm{~nm}$ : $6.06 \mathrm{~min}(P)$, and $21.46 \min (M)$.

Representative procedure for bisphosphinite 5: To a solution of HELIXOL $( \pm)-1$ (51 mg, $0.14 \mathrm{mmol}, 1$ equiv) in THF (degassed by argon bubbling, $1.5 \mathrm{~mL}$ ) were successively added a solution of $\mathrm{N}, \mathrm{N}$ dimethyl-4-aminopyridine $(55 \mathrm{mg}, 0.43 \mathrm{mmol}, 3$ equiv) in THF (degassed by argon bubbling, $1 \mathrm{~mL}$ ) then chlorodiphenylphosphine $(0.10 \mathrm{~mL}, 0.56 \mathrm{mmol}, 4$ equiv). After $18 \mathrm{~h}$ at r.t., the solvent was removed in vacuo and the residue was purified by flash chromatography on basic alumina (hexanes/EtOAc/Et $\left.{ }_{3} \mathrm{~N}: 90: 10: 10\right)$ to afford phosphinite $( \pm)-5$ as a yellow solid (69 mg, $67 \%$ ). $R_{\mathrm{f}}: 0.65$ (petroleum ether/EtOAc: 80:20 on aluminum oxide neutral); HRMS (ESI) $\mathrm{m} / \mathrm{z}$ Calcd. for $\mathrm{C}_{50} \mathrm{H}_{34} \mathrm{O}_{2} \mathrm{P}_{2}\left([\mathrm{M}+\mathrm{K}]^{+}\right)$: 767.1671, found 767.1685; IR (neat): $v\left(\mathrm{~cm}^{-1}\right)=3056,3016,1434,1555,1474,1432,1247,1090$, 1007, 840, 815, 793, 749, 698; ${ }^{1} \mathrm{H}$ NMR $\left(400 \mathrm{MHz}, \mathrm{CD}_{2} \mathrm{Cl}_{2}\right) \delta 7.03$ (app. br d, $J=8.5,2 \mathrm{H}), 7.38-7.24(\mathrm{~m}, 2 \mathrm{H}), 7.49$ (app.t, $J=2.7 \mathrm{~Hz}$, $2 \mathrm{H}), 7.56(\mathrm{~d}, J=8.7 \mathrm{~Hz}, 2 \mathrm{H}), 7.80(\mathrm{~d}, J=8.5 \mathrm{~Hz}, 2 \mathrm{H}), 7.86(\mathrm{~d}, J=$ $8.5 \mathrm{~Hz}, 2 \mathrm{H}), 7.97(\mathrm{~d}, J=8.2 \mathrm{~Hz}, 2 \mathrm{H}), 8.00(\mathrm{~d}, J=8.2 \mathrm{~Hz}, 2 \mathrm{H}) ;{ }^{31} P \mathrm{NMR}$ $\left(162 \mathrm{MHz}, \mathrm{CD}_{2} \mathrm{Cl}_{2}\right): \delta 108.04$.

Seleneted complex $( \pm)-5=S e$ : To a solution of $( \pm)-5(24.9 \mathrm{mg}$, $0.034 \mathrm{mmol}, 1$ equiv) in $\mathrm{CHCl}_{3}(1 \mathrm{~mL})$ was added Selenium $(22.8 \mathrm{mg}$, $0.29 \mathrm{mmol}, 8.5$ equiv). After $18 \mathrm{~h}$ at $80^{\circ} \mathrm{C}$, the reaction mixture was filtered over Celite $\left(\mathrm{CHCl}_{3}\right)$ then concentrated in vacuo to afford ( \pm )$\mathbf{5}=$ Se $(28.9 \mathrm{mg}, 96 \%)$ as a yellow solid; melting point: $245-250{ }^{\circ} \mathrm{C}$ (decomposed); HRMS (ESI) $\mathrm{m} / \mathrm{z}$ Calcd. for $\mathrm{C}_{50} \mathrm{H}_{34} \mathrm{O}_{2} \mathrm{P}_{2} \mathrm{Se}_{2}\left(\left[\mathrm{M}+\mathrm{Na}^{+}\right]^{+}\right)$: 911, 0269, found 911.0277; IR (neat): $v\left(\mathrm{~cm}^{-1}\right)=3049,2963,2920$, 2852, 2360, 2332 1256, 1102, 1015, 804, 700, 648; ${ }^{1} \mathrm{H}$ NMR (400 MHz, $\left.\mathrm{CDCl}_{3}\right) \delta 7.19(\mathrm{ddd}, J=8.6,2.4,1.3 \mathrm{~Hz}, 2 \mathrm{H}), 7.28-7.22(\mathrm{~m}, 6 \mathrm{H}), 7.32-$ 7.37 (m, 2H), 7.53-7.42 (m, 10H), 7.72 (app. d, $J=8.7 \mathrm{~Hz}, 2 \mathrm{H}), 7.75$ $(\mathrm{d}, J=8.5 \mathrm{~Hz}, 2 \mathrm{H}), 7.79(\mathrm{~d}, J=8.7 \mathrm{~Hz}, 2 \mathrm{H}), 7.88(\mathrm{~d}, J=8.2 \mathrm{~Hz}, 2 \mathrm{H})$, $7.90(\mathrm{~d}, J=8.2 \mathrm{~Hz}, 2 \mathrm{H}), 7.91(\mathrm{~d}, J=8.2 \mathrm{~Hz}, 2 \mathrm{H}), 7.95(\mathrm{~d}, J=8.2 \mathrm{~Hz}$, $2 \mathrm{H}) ;{ }^{13} \mathrm{C} \mathrm{NMR}\left(101 \mathrm{MHz}, \mathrm{CDCl}_{3}\right) \delta 119.8\left(\mathrm{~d}, J_{\mathrm{C}-\mathrm{P}}=5.6 \mathrm{~Hz}, 2 \mathrm{CH}\right), 121.2$ $\left(\mathrm{d}, J_{\mathrm{C}-\mathrm{p}}=4.3 \mathrm{~Hz}, 2 \mathrm{CH}\right), 124.0(\mathrm{C}), 126.1(2 \mathrm{CH}), 126.8(2 \mathrm{C}), 127.1(4 \mathrm{CH})$, $127.4(2 \mathrm{CH}), 128.2\left(\mathrm{~d}, J_{\text {metac }-p}=13.7 \mathrm{~Hz}, 4 \mathrm{CH}\right), 128.3(2 \mathrm{CH}), 128.4(\mathrm{~d}$, $\left.J_{\text {metaC }-P}=13.6 \mathrm{~Hz}, 4 \mathrm{CH}\right), 129.2\left(\mathrm{~d}, J_{C-P}=1.6 \mathrm{~Hz}, 2 \mathrm{C}\right), 130.6\left(\mathrm{~d}, J_{C-P}=\right.$ $1.6 \mathrm{~Hz}, 2 \mathrm{C}), 131.0\left(\mathrm{~d}, J_{\text {orthoc- }-P}=7.8 \mathrm{~Hz}, 4 \mathrm{CH}\right), 131.2\left(\mathrm{~d}, J_{\text {orthoc- }-P}=\right.$ $7.8 \mathrm{~Hz}, 4 \mathrm{CH}), 131.6\left(\mathrm{~d}, J_{\text {parac }-p}=3.1 \mathrm{~Hz}, 2 \mathrm{CH}\right), 131.7(2 \mathrm{C}), 131.9(\mathrm{~d}$, $\left.J_{\text {parac }-P}=3.2 \mathrm{~Hz}, 2 \mathrm{CH}\right), 133.9\left(\mathrm{~d}, J_{\text {ipsoC }-P}=173.3 \mathrm{~Hz}, 2 \mathrm{CPh}_{\mathrm{ph}}\right), 133.6(\mathrm{C})$, $134.7\left(\mathrm{~d}, J_{\text {ipsoC }-\mathrm{P}}=177.4 \mathrm{~Hz}, 2 \mathrm{C}_{\mathrm{Ph}}\right.$ ), $148.3\left(\mathrm{~d}, J_{\mathrm{C}-\mathrm{P}}=9.0 \mathrm{~Hz}, 2 \mathrm{C}-\mathrm{O}-\mathrm{P}\right)$ (complex NMR due to ${ }^{31} \mathrm{P} /{ }^{13} \mathrm{C}$ coupling); ${ }^{31} \mathrm{P}$ NMR $\left(162 \mathrm{MHz}, \mathrm{CDCl}_{3}\right.$ ) $\delta 85\left(\mathrm{~d},{ }^{1} J_{P-S e}=826 \mathrm{~Hz}\right)$.
Representative procedure for bisphosphinate 5=O: To a suspension of $\mathrm{NaH}$ (42 mg, $60 \%$ in mineral oil, $1.01 \mathrm{mmol}, 2.5$ equiv) in THF $(1 \mathrm{~mL})$ was added a solution of HELIXOL $( \pm)-1(150 \mathrm{mg}$, $0.42 \mathrm{mmol}, 1$ equiv) in THF ( $1 \mathrm{~mL})$. After $15 \mathrm{~min}$ at r.t., the reaction mixture was cooled down to $0{ }^{\circ} \mathrm{C}$ and diphenylphosphinite chloride $(0.19 \mathrm{~mL}, 1.01 \mathrm{mmol}, 2.5$ equiv) was slowly added. After $15 \mathrm{~min}$ at $0{ }^{\circ} \mathrm{C}$ then $3 \mathrm{~h}$ at r.t., the reaction mixture was quenched at $0{ }^{\circ} \mathrm{C}$ with water $(5 \mathrm{~mL})$ and $\mathrm{Et}_{2} \mathrm{O}(5 \mathrm{~mL})$. The aqueous layer was extracted with $\mathrm{Et}_{2} \mathrm{O}$ then the combined organic extracts were washed with and once with brine, dried with $\mathrm{Na}_{2} \mathrm{SO}_{4}$ then concentrated under reduced pressure. The residue was purified by flash chromatography on silica gel $\left(99: 1=\mathrm{CH}_{2} \mathrm{Cl}_{2} / \mathrm{MeOH}\right)$ to yield $\mathbf{5}=\mathrm{O}(194 \mathrm{mg}, 61 \%)$ as a yellow solid. HRMS (ESI) $\mathrm{m} / z$ Calcd. for $\mathrm{C}_{50} \mathrm{H}_{34} \mathrm{O}_{4} \mathrm{P}_{2}\left(\left[\mathrm{M}+\mathrm{Na}^{+}\right]^{+}\right)$: 783.1825, found 783.1828; melting point: $110^{\circ} \mathrm{C}$; IR (neat): $v\left(\mathrm{~cm}^{-1}\right)$ $=3058,2923,2850,1604,1507,1477,1232,1181,1128,1110,1022$, 980, 927, 884, 751, 728, 692, 610, 574, 544, 528; ${ }^{1} \mathrm{H} \mathrm{NMR}(400 \mathrm{MHz}$, $\left.\mathrm{CDCl}_{3}\right) \delta 7.22$ (apparent br td, $\left.J=7.6,3.6 \mathrm{~Hz}, 4 \mathrm{H}\right), 7.32-7.27(\mathrm{~m}, 2 \mathrm{H})$, 7.37-7.33 (m, 4H), 7.52-7.39 (m, 10H), 7.65-7.54 (m, 4H), $7.73(\mathrm{~d}, J=$ $8.7 \mathrm{~Hz}, 2 \mathrm{H}), 7.87$ (br s, 4H), 7.91 (d, AB syst., $J=8.2 \mathrm{~Hz}, 2 \mathrm{H}), 7.94$ (d, $\mathrm{AB}$ syst., $J=8.2 \mathrm{~Hz}, 2 \mathrm{H}) ;{ }^{13} \mathrm{C} \mathrm{NMR}\left(100 \mathrm{MHz}, \mathrm{CDCl}_{3}\right) \delta{ }^{13} \mathrm{C} \mathrm{NMR}$ $\left(100 \mathrm{MHz}, \mathrm{CDCl}_{3}\right) \delta 118.1\left(\mathrm{~d}, J_{\mathrm{C}-\mathrm{P}}=6.1 \mathrm{~Hz}, 2 \mathrm{CH}\right), 119.7\left(\mathrm{~d}, J_{\mathrm{C}-\mathrm{P}}=\right.$ $3.8 \mathrm{~Hz}, 2 \mathrm{CH}), 124.0(\mathrm{C}), 125.9(2 \mathrm{CH}), 126.8(2 \mathrm{C}), 127.1(2 \mathrm{CH}), 127.2$ (2CH), $127.3(2 \mathrm{CH}), 128.3\left(\mathrm{~d}, J_{\text {metac }-p}=13.5 \mathrm{~Hz}, 4 \mathrm{CH}\right), 128.5\left(\mathrm{~d}, J_{\text {metac }-P}\right.$ $=13.5 \mathrm{~Hz}, 4 \mathrm{CH}), 128.9(2 \mathrm{CH}), 129.0(2 \mathrm{C}), 130.7$ (d, $J_{\text {ipsoC- }-p}=137.9 \mathrm{~Hz}$, 2C), $130.9(2 \mathrm{C}), 131.1\left(\mathrm{~d}, J_{\text {ipsoC- }-\mathrm{P}}=138.8 \mathrm{~Hz}, 2 \mathrm{C}\right), 131.4\left(\mathrm{~d}, J_{\text {orthoC }-\mathrm{P}}=\right.$ $10.4 \mathrm{~Hz}, 4 \mathrm{CH}), 131.5$ (d, Jorthoc- $P=10.4 \mathrm{~Hz}, 4 \mathrm{CH}), 131.8(2 \mathrm{C}), 132.0$ $\left(\mathrm{d}, J_{\text {parac }-P}=2.8 \mathrm{~Hz}, 2 \mathrm{CH}\right), 132.2\left(\mathrm{~d}, J_{\text {parac }-\mathrm{P}}=2.9 \mathrm{~Hz}, 2 \mathrm{CH}\right), 132.9(\mathrm{C})$, $148.3\left(\mathrm{~d}, J_{\mathrm{C}-\mathrm{P}}=8.6 \mathrm{~Hz}, 2 \mathrm{CH}\right)$ (complex NMR due to ${ }^{31} \mathrm{P} /{ }^{13} \mathrm{C}$ coupling); ${ }^{31} P$ NMR $\left(121 \mathrm{MHz} \mathrm{CDCl}_{3}\right) \delta=29.6 \mathrm{ppm} ;(P)-5=\mathrm{O}:[\alpha]_{\mathrm{D}}^{23}=+3295$ ( $\left.c=0.042, \mathrm{CH}_{2} \mathrm{Cl}_{2}, 98 \% \mathrm{ee}\right) ;(M)-5=\mathrm{O}:[\alpha]_{\mathrm{D}}^{23}=-3829$ ( $c=0.040$, $\mathrm{CH}_{2} \mathrm{Cl}_{2}, 96$ \%ee). ${ }^{[14]}$

Representative procedure to access gold complex 6: To a solution of $(P)-5$ (73 mg, $0.10 \mathrm{mmol}, 1$ equiv) in $\mathrm{CH}_{2} \mathrm{Cl}_{2}(20 \mathrm{~mL})$ was added $\mathrm{AuCl}\left(\mathrm{Me}_{2} \mathrm{~S}\right)(62 \mathrm{mg}, 0.21 \mathrm{mmol}, 2.1$ equiv). After $18 \mathrm{~h}$ at r.t., the reaction mixture was concentrated under reducer pressure. The residue was dissolved in dichloromethane and purified by precipitation with pentane to obtain (P)-6 (119 mg, quant.) as a white solid. The complex was crystallized by diffusion of pentane into the solution of product in $\mathrm{CH}_{2} \mathrm{Cl}_{2}$ to afford colorless crystal. Melting point: $245-250{ }^{\circ} \mathrm{C}$ (decomposed); HRMS (ESI) $\mathrm{m} / \mathrm{z}$ calcd. for $\mathrm{C}_{50} \mathrm{H}_{34} \mathrm{Au}_{2} \mathrm{ClO}_{2} \mathrm{P}_{2}\left(\left[\mathrm{M}-\mathrm{Cl}^{-}\right]^{+}\right)$: 1157.1054, found 1157.1010; Calcd for $\mathrm{C}_{50} \mathrm{H}_{34} \mathrm{AuO}_{2} \mathrm{P}_{2}\left(\left[\mathrm{M}-\mathrm{AuCl}_{2}^{-}\right]^{+}\right)$: 925.1694, found 925.1720; IR (neat): $v\left(\mathrm{~cm}^{-1}\right)=3038,2920,2845,1607,1428,1166,1105,908,847,746$, 645; ${ }^{1} \mathrm{H}$ NMR $\left(400 \mathrm{MHz}, \mathrm{CD}_{2} \mathrm{Cl}_{2}\right) \delta 7.33-7.28(\mathrm{~m}, 4 \mathrm{H}), 7.45-7.39(\mathrm{~m}$, $4 \mathrm{H}), 7.64-7.48(\mathrm{~m}, 16 \mathrm{H}), 7.70(\mathrm{~d}, J=8.3 \mathrm{~Hz}, 2 \mathrm{H}), 7.73(\mathrm{~d}, J=8.6 \mathrm{~Hz}$, $2 \mathrm{H}), 7.89(\mathrm{~d}, J=8.6 \mathrm{~Hz}, 2 \mathrm{H}), 7.99(\mathrm{~d}, J=8.3 \mathrm{~Hz}, 2 \mathrm{H}), 8.04(\mathrm{~d}, J=$ $8.3 \mathrm{~Hz}, 2 \mathrm{H}) ;{ }^{13} \mathrm{C} \mathrm{NMR}\left(150 \mathrm{MHz}, \mathrm{CD}_{2} \mathrm{Cl}_{2}\right) \delta 118.7\left(\mathrm{~d}, J_{\mathrm{C}-\mathrm{P}}=6.4 \mathrm{~Hz}\right.$, $2 \mathrm{CH}), 121.0\left(\mathrm{~d}, J_{\mathrm{C}-\mathrm{p}}=5.9 \mathrm{~Hz}, 2 \mathrm{CH}\right), 124.3(\mathrm{C}), 126.9(2 \mathrm{CH}), 127.1(2 \mathrm{C})$, $127.9(2 \mathrm{CH}), 128.0(2 \mathrm{CH}), 128.2(2 \mathrm{CH}), 129.68\left(\mathrm{~d}, J_{\mathrm{C}-\mathrm{P}}=12.9 \mathrm{~Hz}, 4 \mathrm{CH}\right)$, $129.69\left(\mathrm{~d}, J_{\mathrm{C}-\mathrm{p}}=12.6 \mathrm{~Hz}, 4 \mathrm{CH}\right), 129.9(2 \mathrm{C}), 130.4(2 \mathrm{CH}), 131.2(2 \mathrm{C})$, $132.2\left(d, J_{C-P}=16.3 \mathrm{~Hz}, 4 \mathrm{CH}\right), 132.5(2 \mathrm{C}), 132.6\left(\mathrm{~d}, J_{\mathrm{C}-\mathrm{P}}=16.3 \mathrm{~Hz}\right.$, $4 \mathrm{CH}), 133.2\left(\mathrm{~d}, J_{\mathrm{C}-\mathrm{P}}=2.5 \mathrm{~Hz}, 2 \mathrm{CH}\right), 133.3\left(\mathrm{~d}, J_{\mathrm{C}-\mathrm{P}}=2.5 \mathrm{~Hz}, 2 \mathrm{CH}\right)$, $133.5\left(\mathrm{~d}, J_{\mathrm{C}-\mathrm{P}}=71.0 \mathrm{~Hz}, 2 \mathrm{CH}\right), 133.6\left(\mathrm{~d}, J_{\mathrm{C}-\mathrm{P}}=70.0 \mathrm{~Hz}, 2 \mathrm{C}\right), 133.7(\mathrm{C})$, $152.2\left(\mathrm{~d}, J_{C-P}=5.5 \mathrm{~Hz}, 2 \mathrm{C}\right)$ (complex NMR due to ${ }^{31} \mathrm{P} /{ }^{13} \mathrm{C}$ coupling); ${ }^{31} P$ NMR $\left(162 \mathrm{MHz}, \mathrm{CDCl}_{3}\right) \delta 112.3(\mathrm{~s}) .(P)-6:[\alpha]_{\mathrm{D}}^{23}=+1244(c=0.005$, $\left.\mathrm{CHCl}_{3}\right) ;(M)-6:[\alpha]_{D}^{23}=-1250\left(c=0.005, \mathrm{CHCl}_{3}\right)$.

Representative procedure for enyne 8 cycloisomerization: To a solution of bis-gold complex 6 (x equiv) in $\mathrm{CH}_{2} \mathrm{Cl}_{2}$ was added $\mathrm{AgSbF}_{6}$ (y equiv). After $5 \mathrm{~min}$ at r.t., $\mathrm{AgCl}$ precipitation was observed. The reaction mixture was cooled to $0{ }^{\circ} \mathrm{C}$ and a solution of 1,6-enyne 8 ( 1 equiv) in $\mathrm{CH}_{2} \mathrm{Cl}_{2}$ (final concentration $0.05 \mathrm{M}$ ) was added then the reaction mixture was stirred at room temperature. After completion, the reaction was quenched with $\mathrm{Et}_{3} \mathrm{~N}$, then fil- 
tered through a short pad of Celite ${ }^{\circledR}\left(\mathrm{CH}_{2} \mathrm{Cl}_{2}\right)$ and concentrated in vacuo. The residue was purified by flash chromatography on silica gel to afford the cyclic product $\mathbf{9}$ which spectroscopic description matched the data reported in the literature.

\section{Acknowledgments}

This work was supported by the CNRS, Sorbonne Université, IUF and Agence Nationale de la Recherche (ANR-13-JS07-0013HELCATS). We warmly thank D. Marquez, S. Queric, S. Zhang and $C$. Fagnan for precursor synthesis, J. Forté for X-ray structure of $( \pm)-\mathbf{5}=$ Se and Dr. A. Voituriez for fruitful discussions.

Keywords: Helicene - Phosphinite - Homogeneous catalysis · Chirality · Enyne Cycloisomerization

[1] For recent reviews and book, see: a) C.-F. Chen, Y. Shen, Helicene Chemistry, Springer-Verlag Berlin Heidelberg, 2017; b) N. Saleh, C. Shen, J. Crassous, Chem. Sci. 2014, 5, 3680-3694; c) P. Aillard, A. Voituriez, A. Marinetti, Dalton Trans. 2014, 43, 15263-15278; d) M. J. Narcis, N. Takenaka, Eur. J. Org. Chem. 2014, 2014, 21-34; e) Y. Shen, C.-F. Chen, Chem. Rev. 2012, 112, 1463-1535; f) M. Gingras, Chem. Soc. Rev. 2013, 42, 1051-1095.

[2] M. T. Reetz, S. Sostmann, Tetrahedron 2001, 57, 2515-2520.

[3] Photocyclization: a) C. Wachsmann, E. Weber, M. Czugler, W. Seichter, Eur. J. Org. Chem. 2003, 2003, 2863-2876; [2+2+2] cycloaddition: b) F. Teplý, I. G. Stará, I. Starý, A. Kollárovič, D. Luštinec, Z. Krausová, D. Šaman, P. Fiedler, Eur. J. Org. Chem. 2007, 2007, 4244-4250.

[4] a) Reviews on gold catalyzed cycloisomerization: C. Aubert, L. Fensterbank, P. Garcia, M. Malacria, A. Simonneau, Chem. Rev. 2011, 111, 19541993; b) M. Rudolph, A. S. K. Hashmi, Chem. Soc. Rev. 2012, 41, 2448 2462; c) W. Yang, A. S. K. Hashmi, Chem. Soc. Rev. 2014, 43, 2941-2955; d) Y.-M. Wang, A. D. Lackner, F. D. Toste, Acc. Chem. Res. 2014, 47, 889901; e) C. Obradors, A. M. Echavarren, Chem. Commun. 2014, 50, 16-28; f) A. Fürstner, Acc. Chem. Res. 2014, 47, 925-938.

[5] a) I. G. Stará, I. Starý, A. Kollárovič, F. Teplý, Š. Vyskočil, D. Šaman, Tetrahedron Lett. 1999, 40, 1993-1996; b) M. Šámal, S. Chercheja, J. Rybáček, J. V. Chocholoušová, J. Vacek, L. Bednarova, D. Šaman, I. G. Stará, I. Starý, J. Am. Chem. Soc. 2015, 137, 8469-8474.

[6] H. F. Klein, Angew. Chem. Int. Ed. Engl. 1970, 9, 904-904; Angew. Chem. 1970, 82, 885-886.

[7] S. Ventre, C. Simon, F. Rekhroukh, M. Malacria, M. Amatore, C. Aubert, M. Petit, Chem. Eur. J. 2013, 19, 5830-5835.

[8] A unique example of phosphinite held on a helical scaffold was reported in the literature, see: T. Tsujihara, N. Inado-Nozaki, T. Takehara, D. Y. Zhou, T. Suzuki, T. Kawano, Eur. J. Org. Chem. 2016, 4948-4952.

[9] a) D. W. Allen, L. A. March, I. W. Nowell, J. Chem. Soc., Dalton Trans. 1984, 483-485; b) D. W. Allen, B. F. Taylor, J. Chem. Soc., Dalton Trans. 1982, $51-54$.
[10] M. S. Balakrishna, R. Panda, J. T. Mague, J. Chem. Soc., Dalton Trans. 2002, 4617-4621.

[11] C. Glidewell, E. J. Leslie, J. Chem. Soc., Dalton Trans. 1977, 527-531.

[12] For previous gold complexes bearing a helical core and their use in catalysis, see: a) K. Yavari, P. Aillard, Y. Zhang, F. Nuter, P. Retailleau, A. Voituriez, A. Marinetti, Angew. Chem. Int. Ed. 2014, 53, 861-865; Angew. Chem. 2014, 126, 880-884; b) K. Yavari, P. Retailleau, A. Voituriez, A. Marinetti, Chem. Eur. J. 2013, 19, 9939-9947; c) S. Cauteruccio, A. Loos, A. Bossi, M. C. B. Jaimes, D. Dova, F. Rominger, S. Prager, A. Dreuw, E. Licandro, A. S. K. Hashmi, Inorg. Chem. 2013, 52, 7995-8004; d) P. Aillard, A. Voituriez, D. Dova, S. Cauteruccio, E. Licandro, A. Marinetti, Chem. Eur. J. 2014, 20, 12373-12376; e) P. Aillard, P. Retailleau, A. Voituriez, A. Marinetti, Chem. Eur. J. 2015, 21, 11989-11993.

[13] HPLC conditions: Chiralpak IA $(250 \times 10 \mathrm{~mm})$, hexane/ethanol/chloroform (20:40:40), flow-rate $=5 \mathrm{~mL} / \mathrm{min}$, UV detection at $280 \mathrm{~nm}$. Retention times: $3.34((P)-\mathbf{1}$, ee>99.5) and $4.82((M)-\mathbf{1}$, ee>99.5).

[14] ee were determined via chiral HPLC, conditions: Chiralpak IF $(250 \times 4.6 \mathrm{~mm}, 5$ microns), heptane/ethanol/dichloromethane (5:3:2), flow-rate $=1 \mathrm{~mL} / \mathrm{min}$, UV detection at $254 \mathrm{~nm}$ and polarimetric detection (Jasco OR-1590), Retention times: $(P)-5=0=7.2 \mathrm{~min},(M)-5=0=$ $13.0 \mathrm{~min}$, see supporting information. The difference in optical rotation probably arose from hydration, as bisphosphinates are highly hygroscopic.

[15] L. Norel, M. Rudolph, N. Vanthuyne, J. A. G. Williams, C. Lescop, C. Roussel, J. Autschbach, J. Crassous, R. Réau, Angew. Chem. Int. Ed. 2010, 49, 99-102; Angew. Chem. 2010, 122, 103-106.

[16] ee was determined by using a Chiralpak AS-H Column, 98:2 n-hexane/ $i \mathrm{PrOH}, 1 \mathrm{~mL} / \mathrm{min}$. Retention time for major enantiomer: $52.54 \mathrm{~min}$; for minor enantiomer: $65.46 \mathrm{~min}$. Attribution of the absolute configuration was done in agreement with the data published in the literature, see: P. Zhang, C. Tugny, J. M. Suarez, M. Guitet, E. Derat, N. Vanthuyne, Y. Zhang, O. Bistri, V. Mouries-Mansuy, M. Menand, Chem 2017, 3, 174-191.

[17] ee was determined by using a Chiralpak AD-H column (95:5 $n$-hexanes/ $i \mathrm{PrOH}, 1 \mathrm{~mL} / \mathrm{min}$ ): Retention time for minor enantiomer: $5.58 \mathrm{~min}$; for major enantiomer: $6.57 \mathrm{~min}$. Attribution of the absolute configuration was done in agreement with the data published in the literature, see: a) K.-i. Yamada, Y. Matsumoto, K. B. Selim, Y. Yamamoto, K. Tomioka, Tetrahedron 2012, 68, 4159-4165; b) M. P. Muñoz, J. Adrio, J. C. Carretero, A. M. Echavarren, Organometallics 2005, 24, 1293-1300.

[18] T. Shibata, Y. Kobayashi, S. Maekawa, N. Toshida, K. Takagi, Tetrahedron 2005, 61, 9018-9024.

[19] M. Barbazanges, M. Auge, J. Moussa, H. Amouri, C. Aubert, C. Desmarets, L. Fensterbank, V. Gandon, M. Malacria, C. Ollivier, Chem. Eur. J. 2011, 17, 13789-13794.

[20] T. Kudoh, T. Mori, M. Shirahama, M. Yamada, T. Ishikawa, S. Saito, H. Kobayashi, J. Am. Chem. Soc. 2007, 129, 4939-4947.

[21] F. Schröder, C. Tugny, E. Salanouve, H. Clavier, L. Giordano, D. Moraleda, Y. Gimbert, V. Mouries-Mansuy, J.-P. Goddard, L. Fensterbank, Organometallics 2014, 33, 4051-4056. 


\section{Supporting information}

1) NMR spectra $\left({ }^{1} \mathrm{H},{ }^{13} \mathrm{C},{ }^{31} \mathrm{P}\right)$ of precursor 2 and helical structures $1,3,4,5=\mathrm{Se}$,

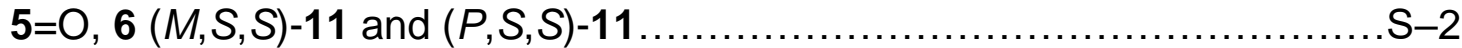

2) Bisphosphinate $5=0$ chiral HPLC analysis …...............................

3) Asymmetric catalysis: HPLC traces ....................................... -25

4) ${ }^{1} \mathrm{H}$ and ${ }^{13} \mathrm{C}$ spectra of cycloisomerization products ............................ -30 


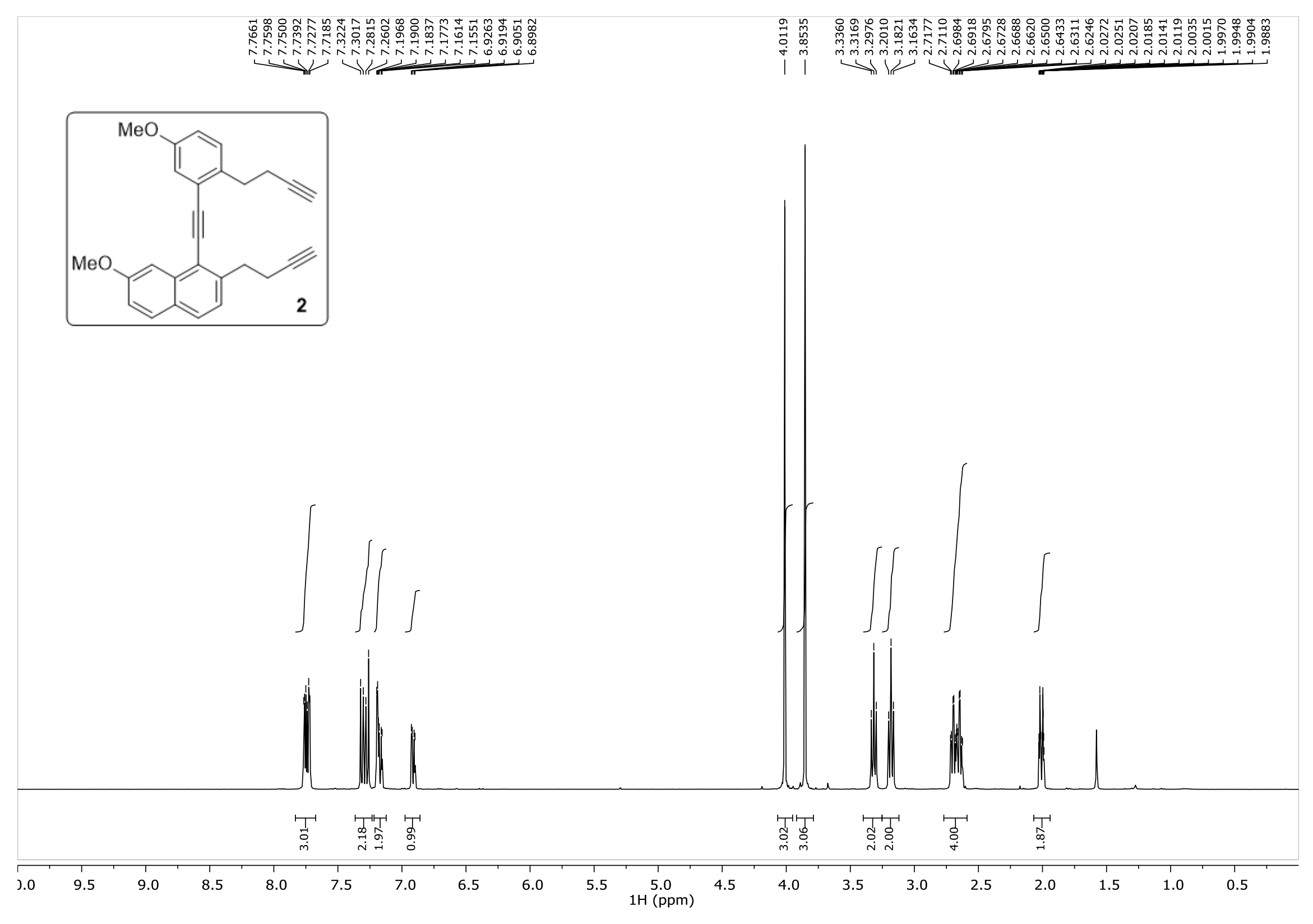




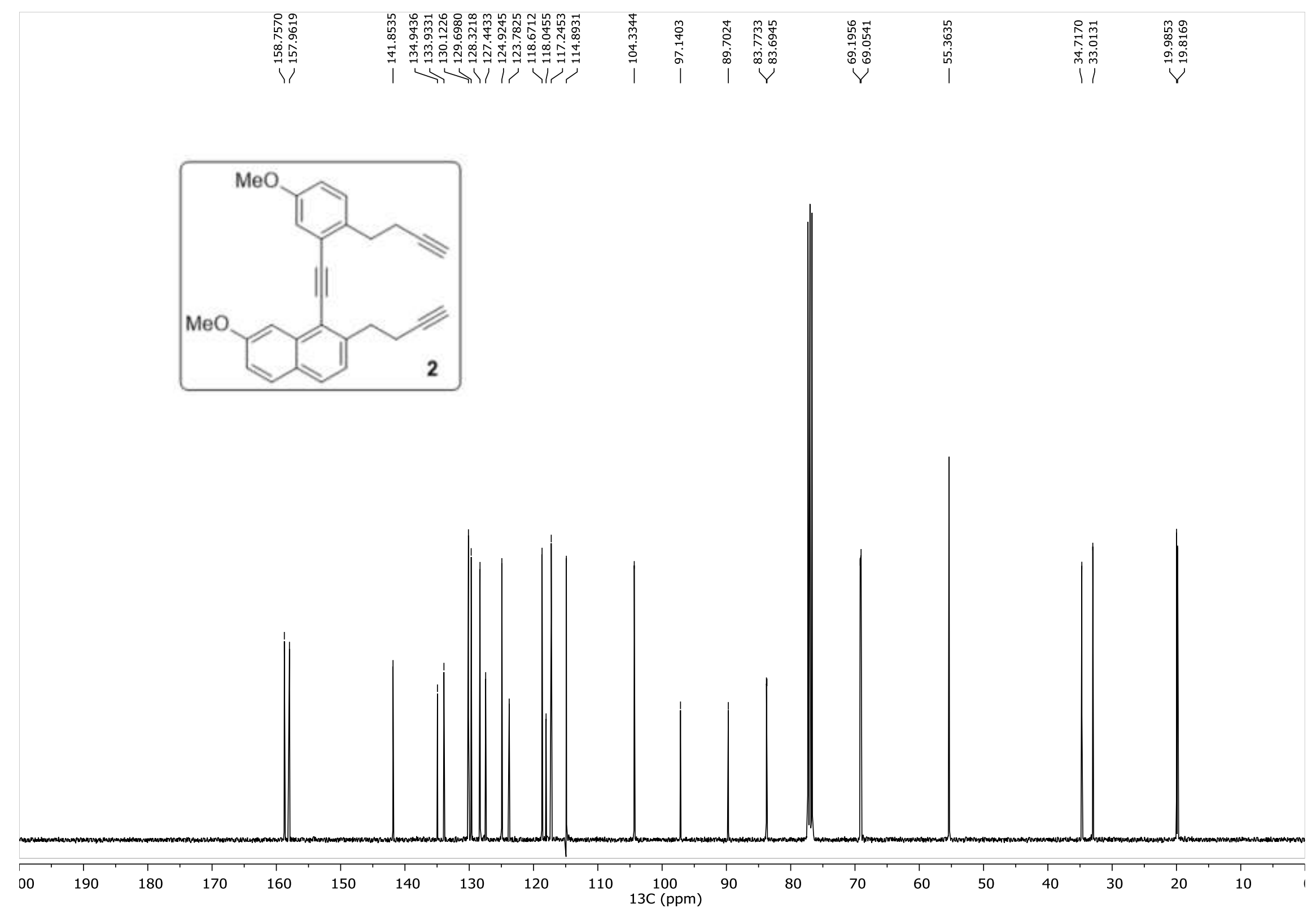




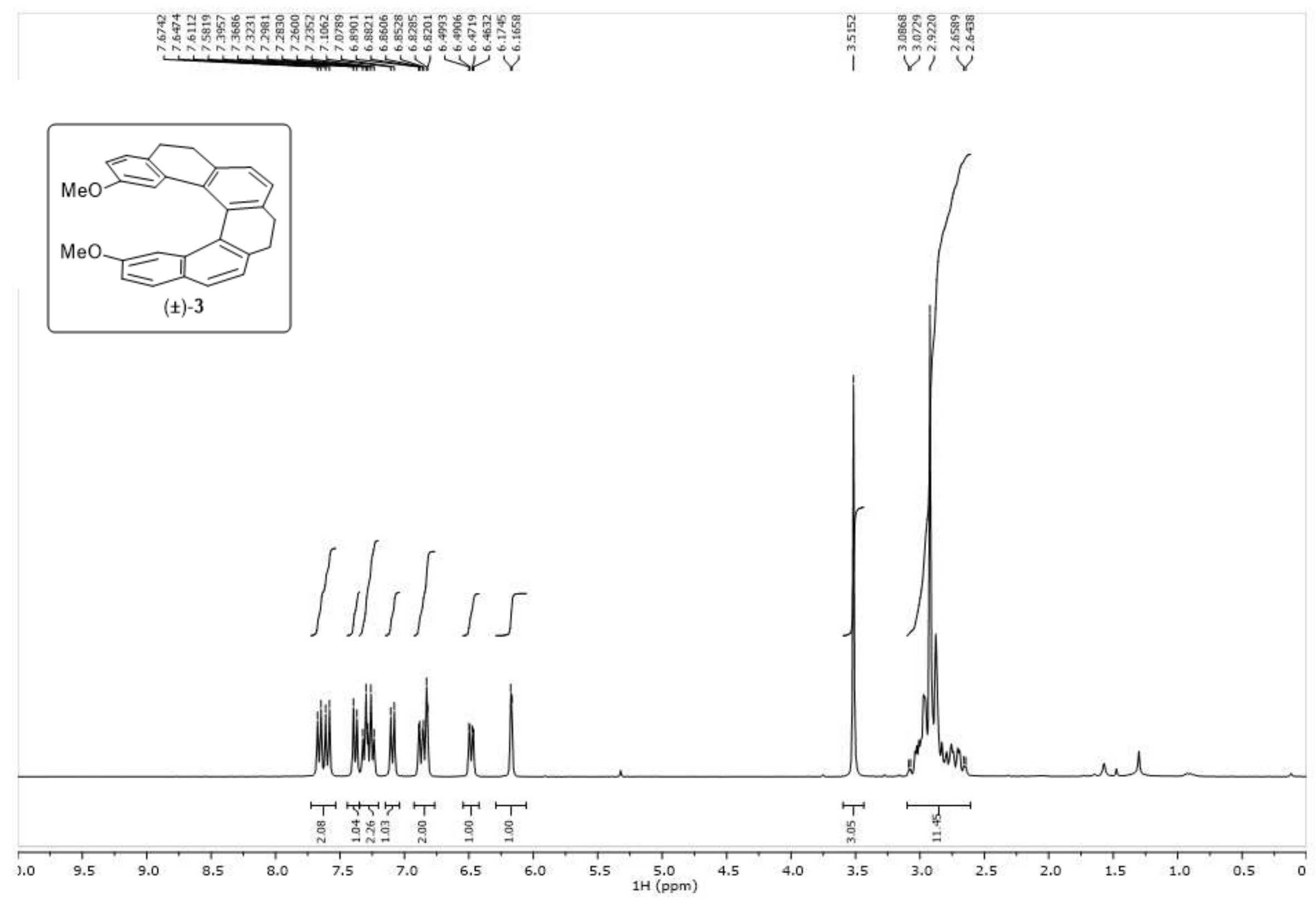




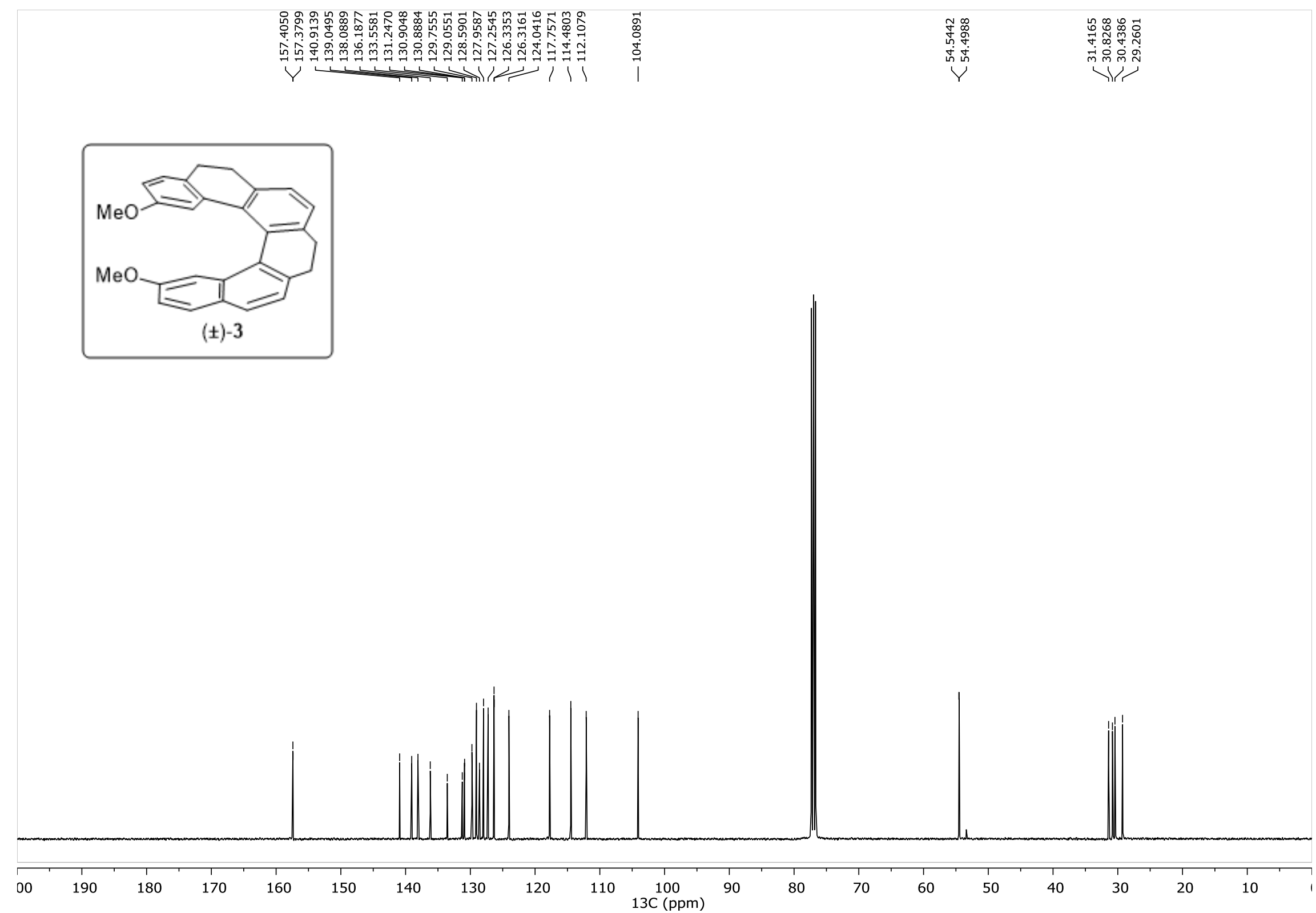




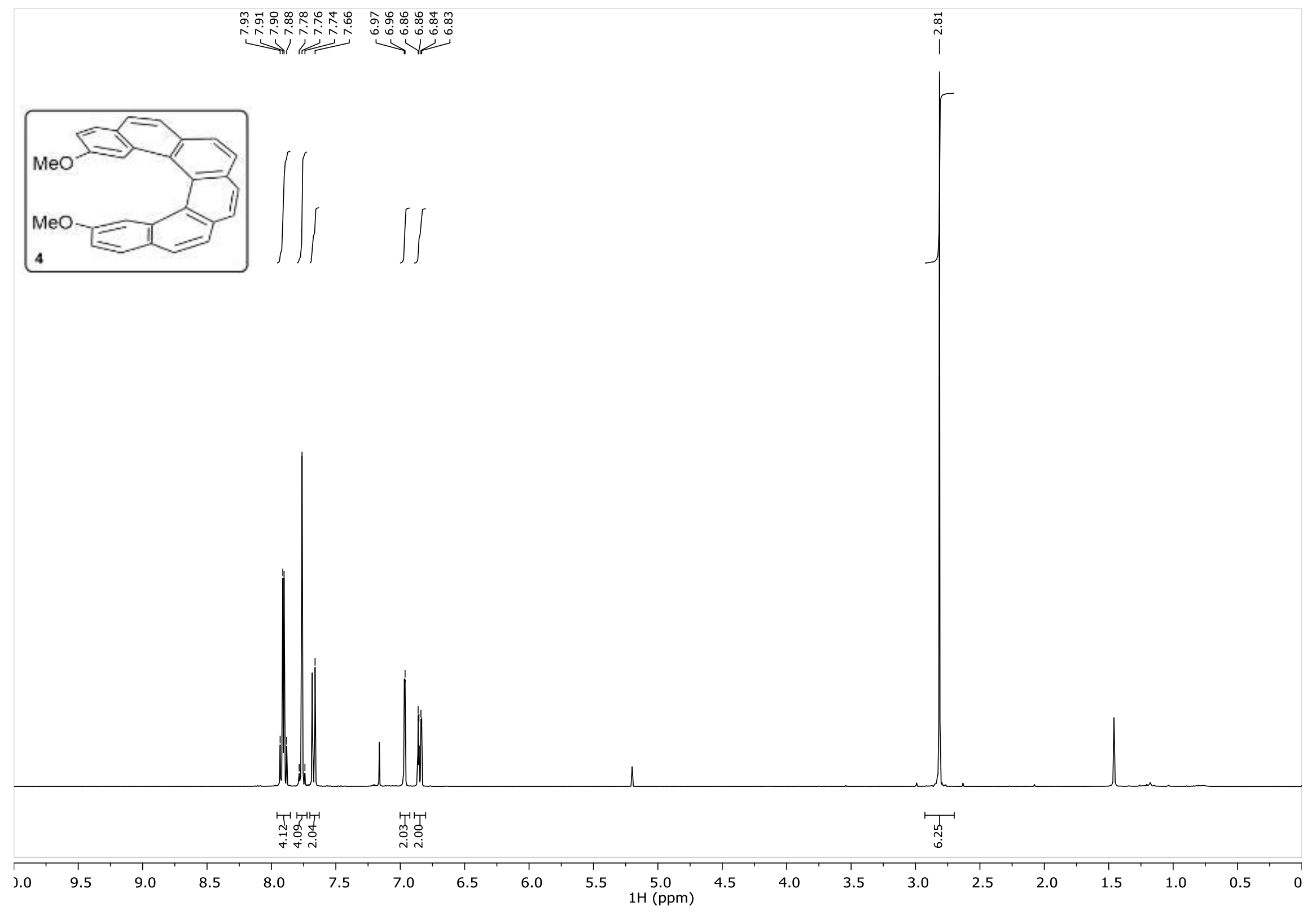




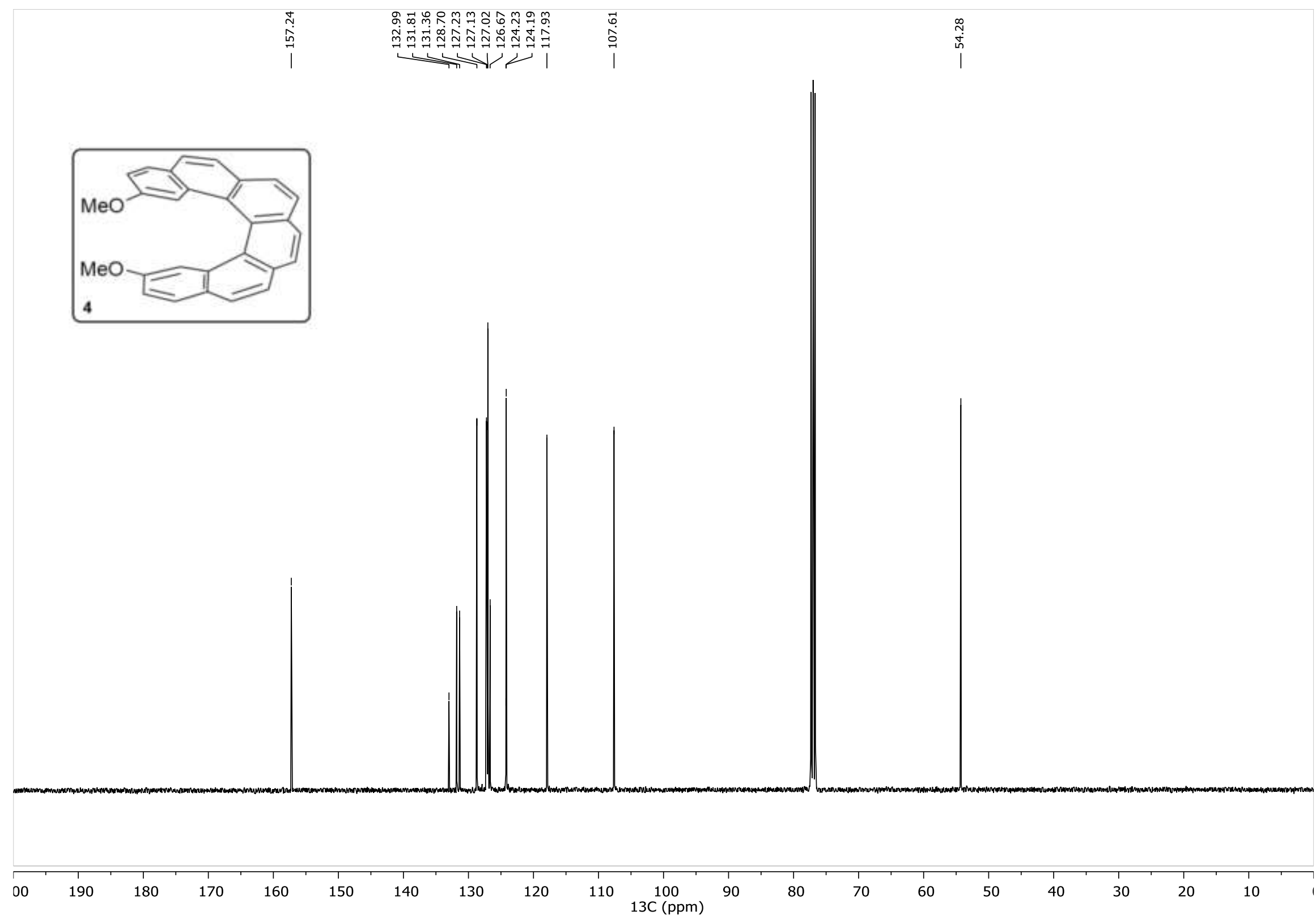




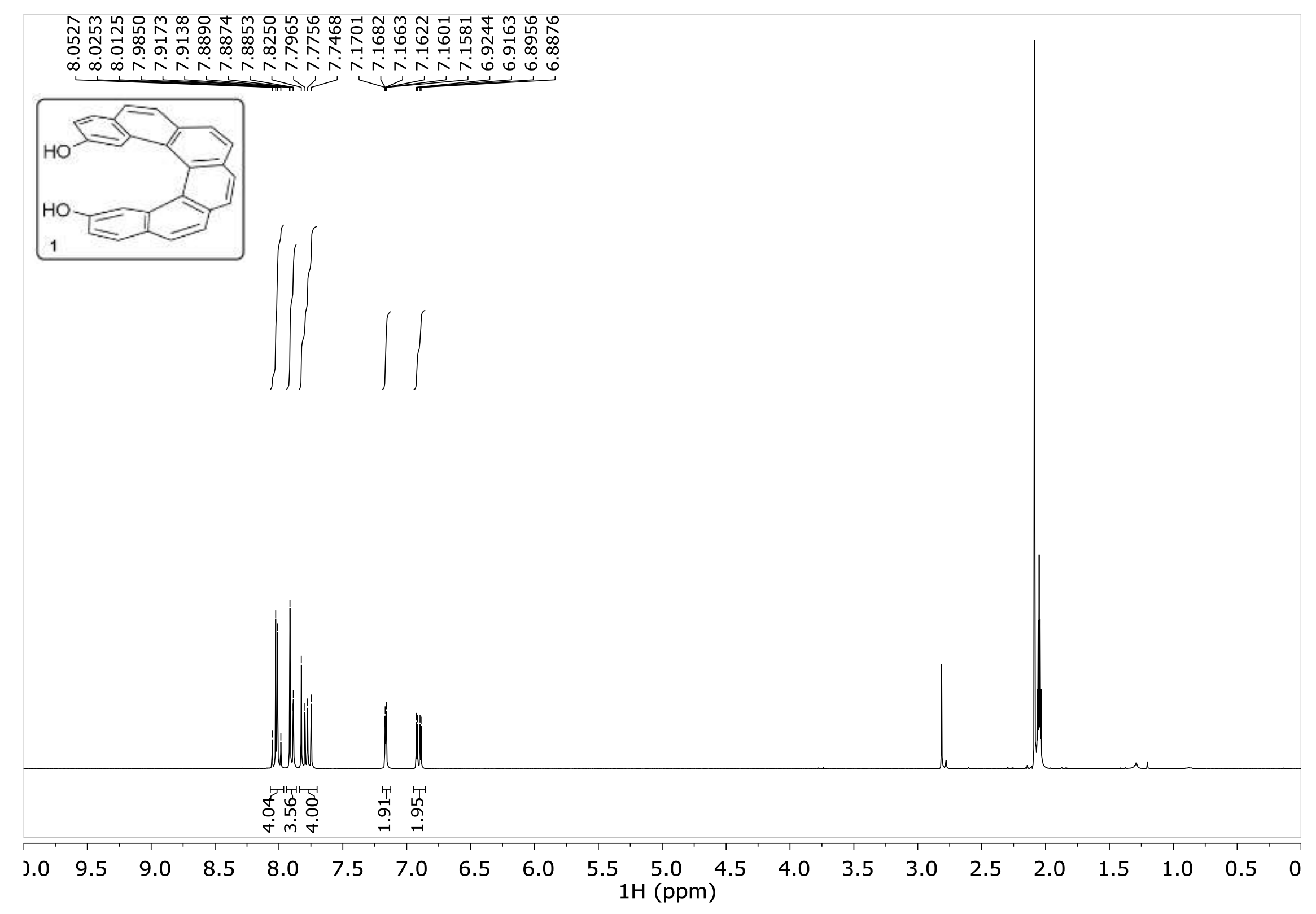




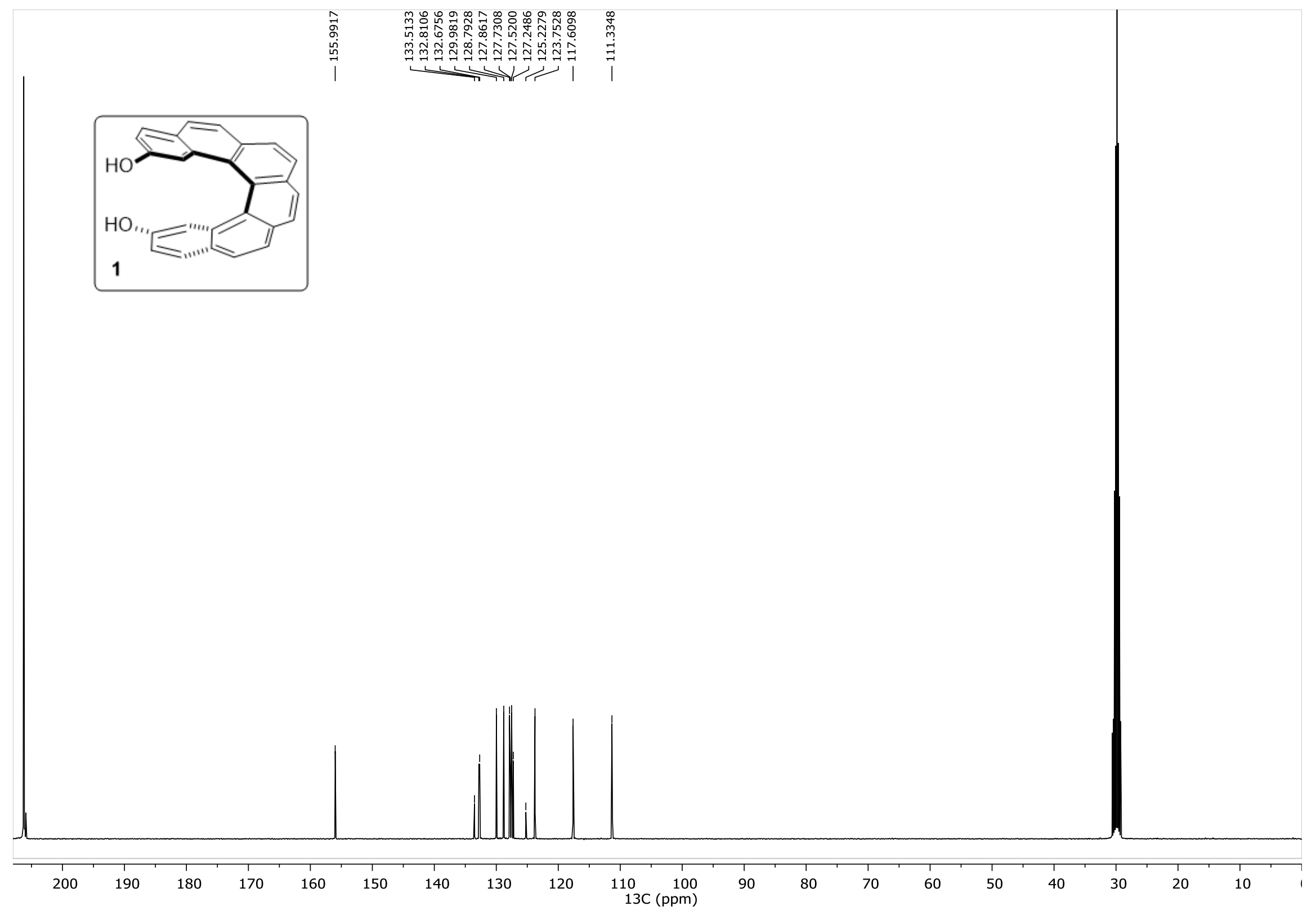



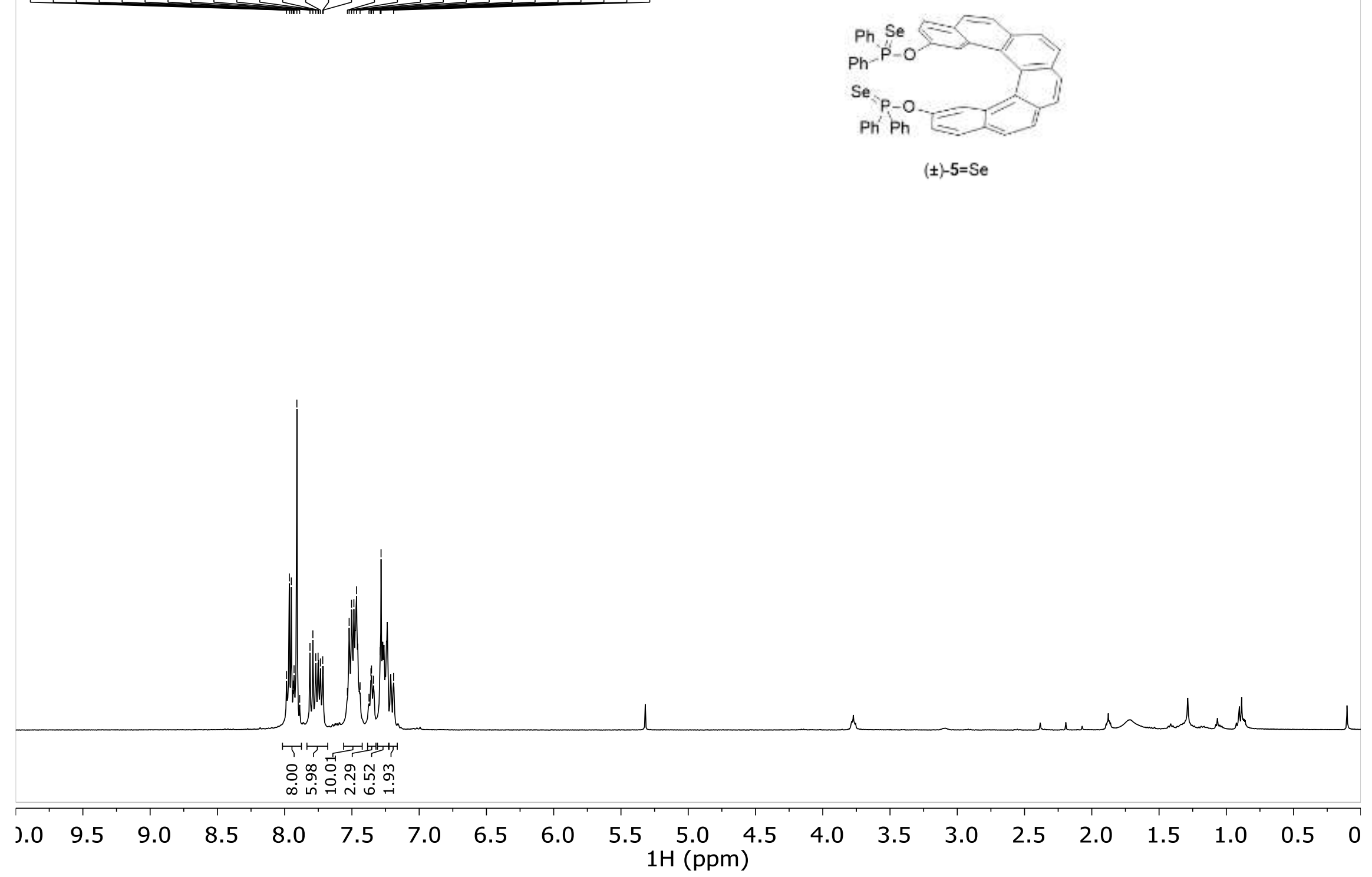


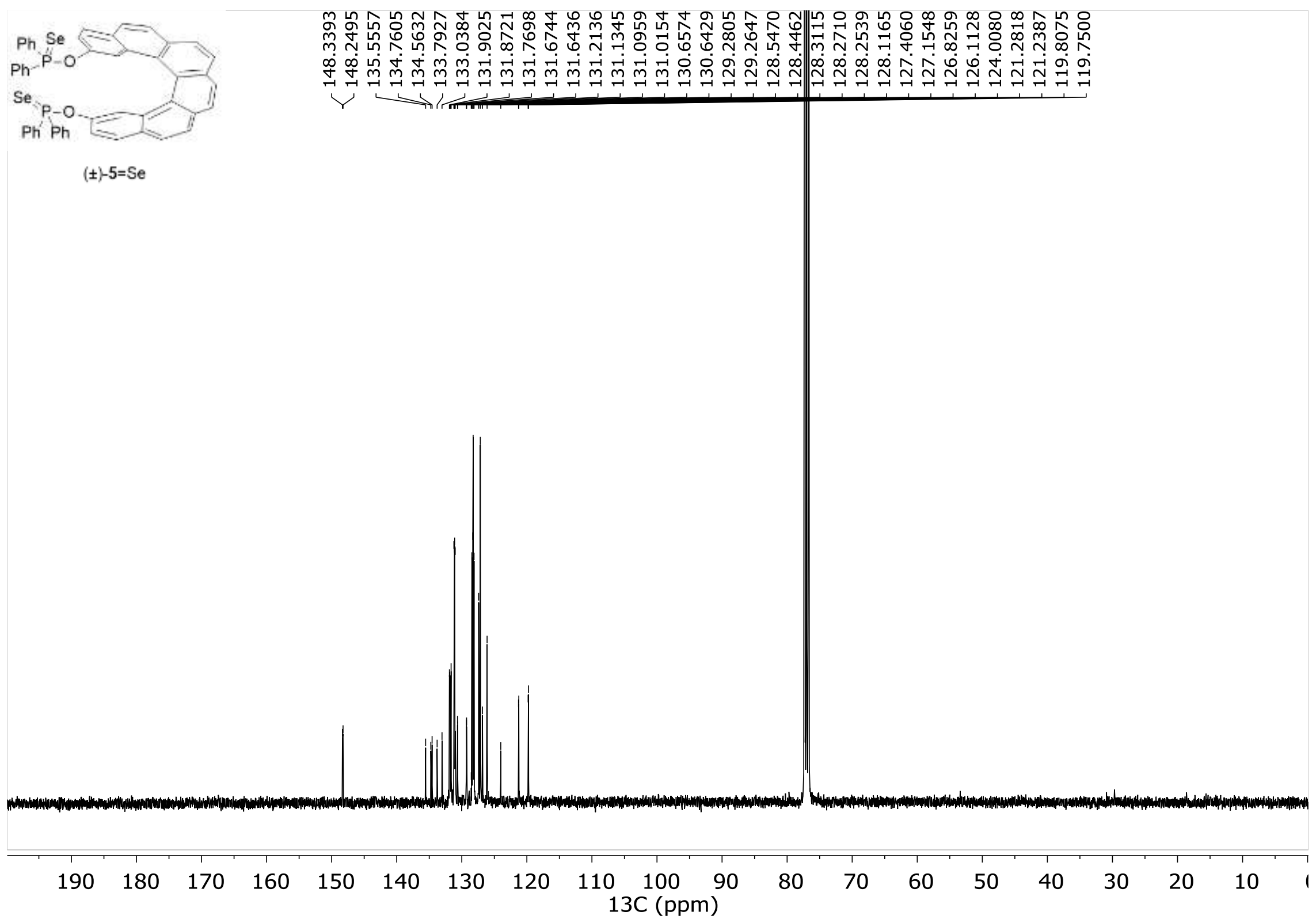




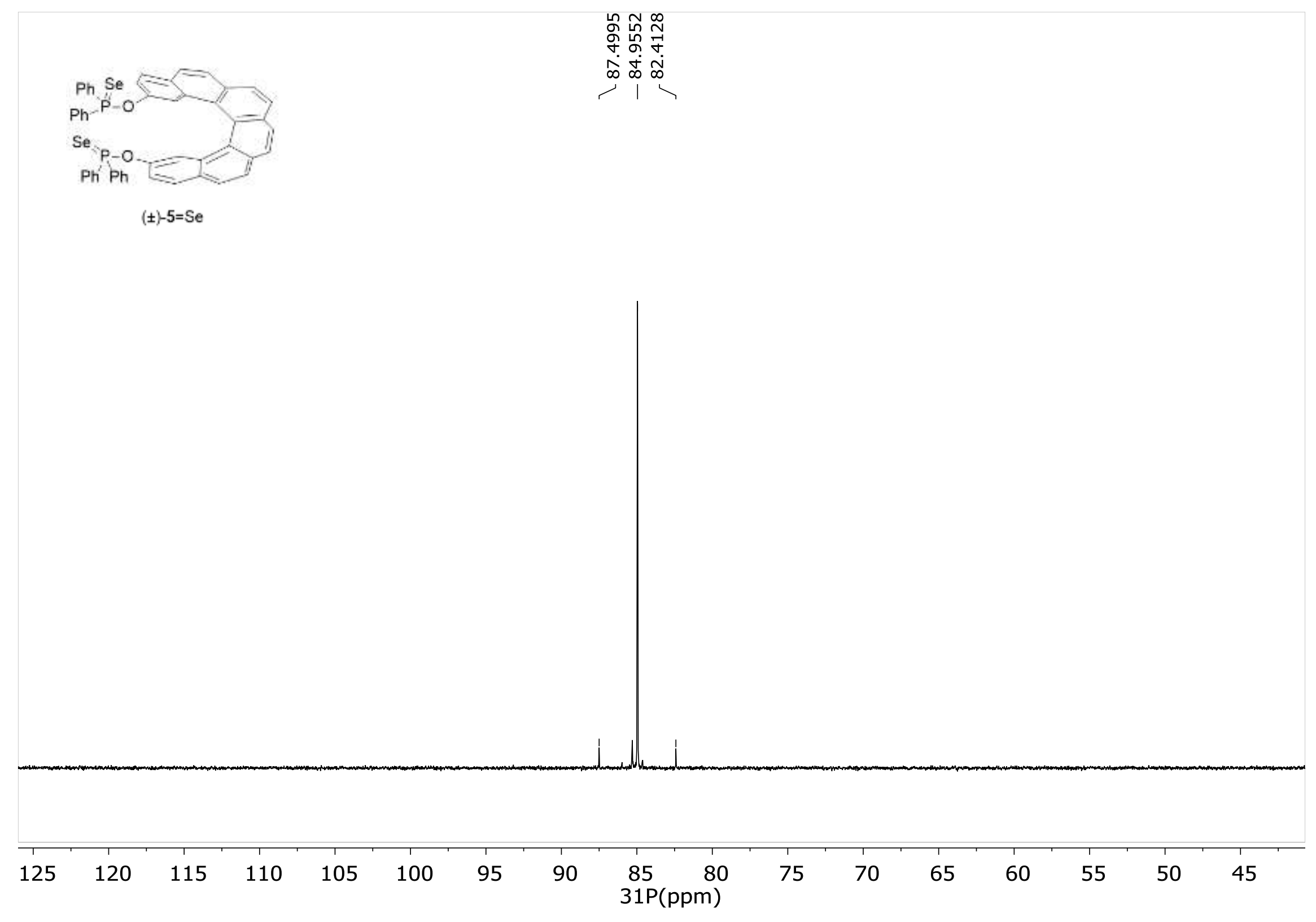




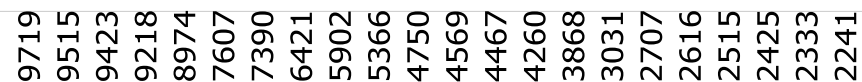

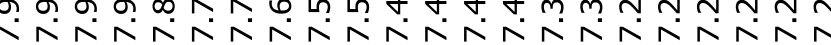
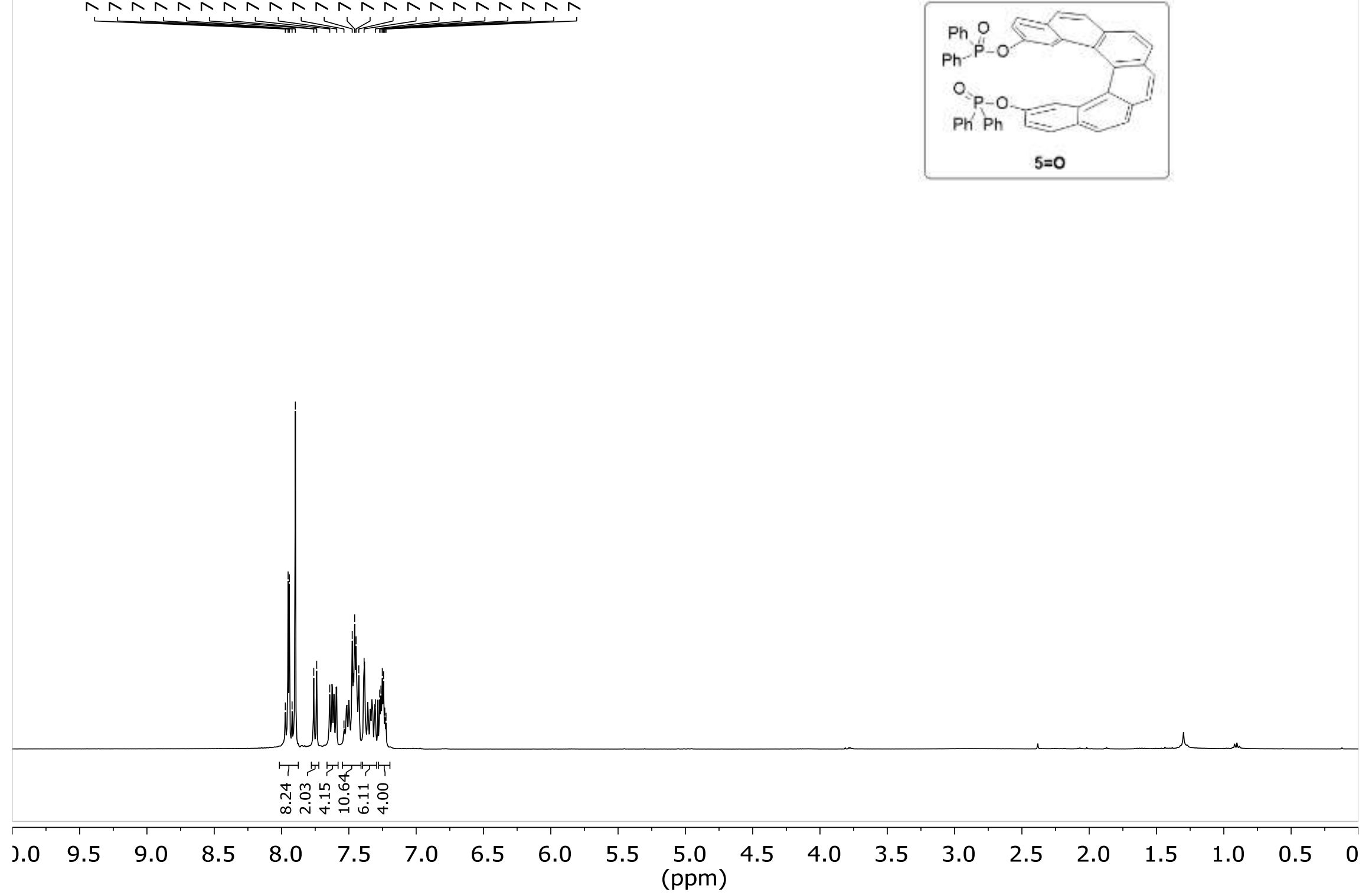

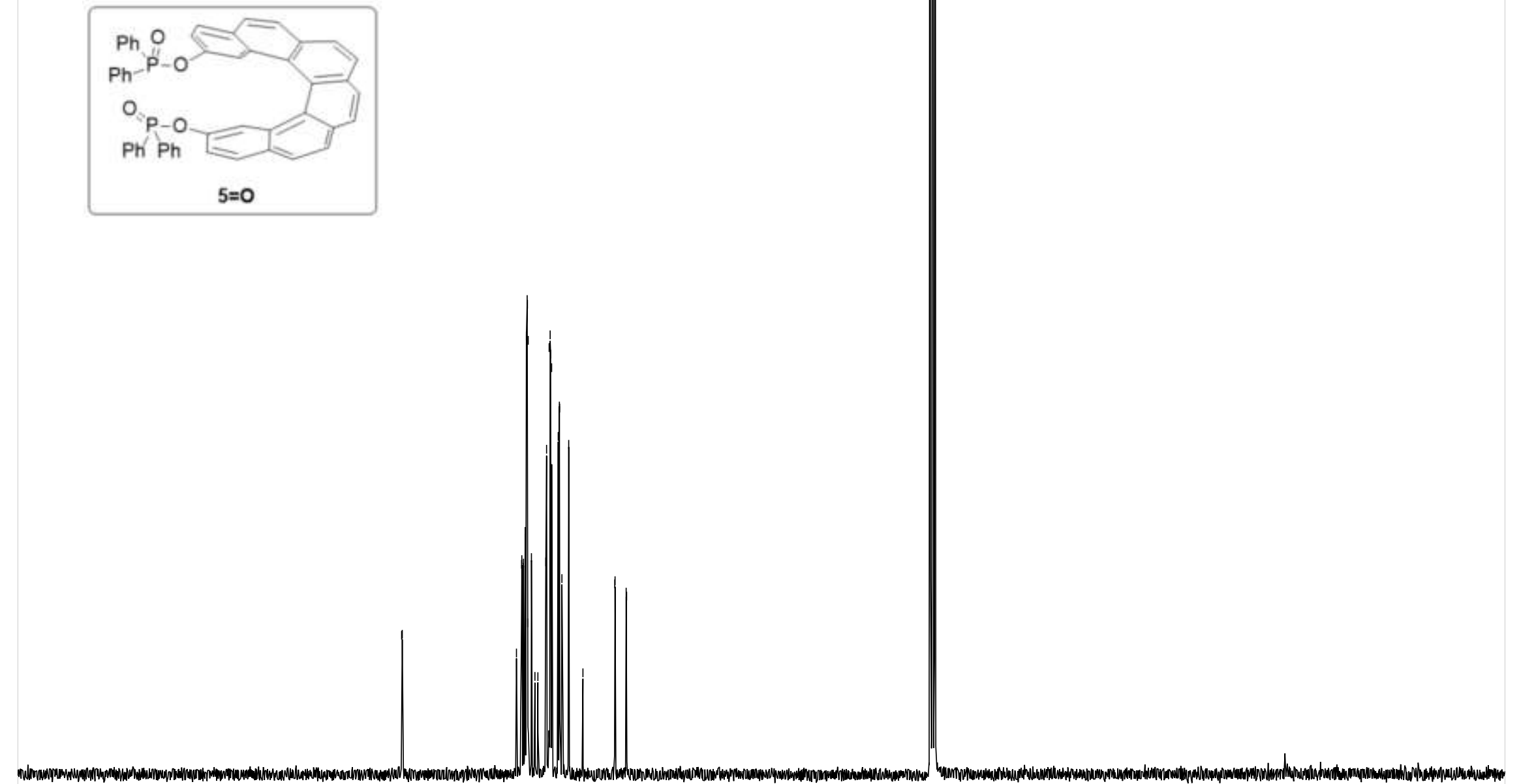


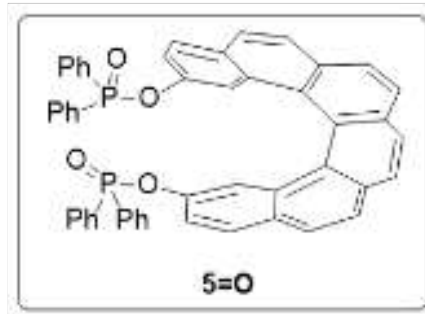

กิ
กุ่
กิ

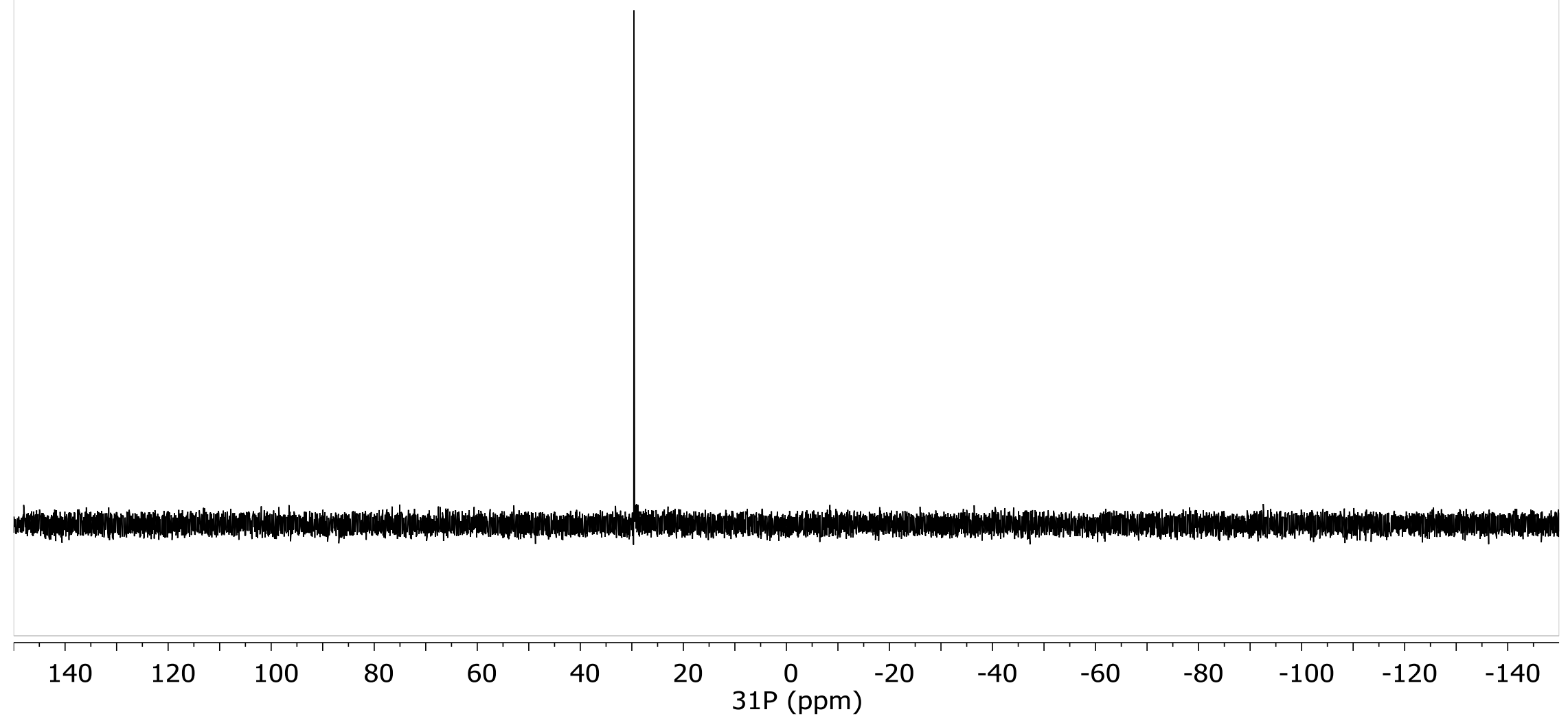



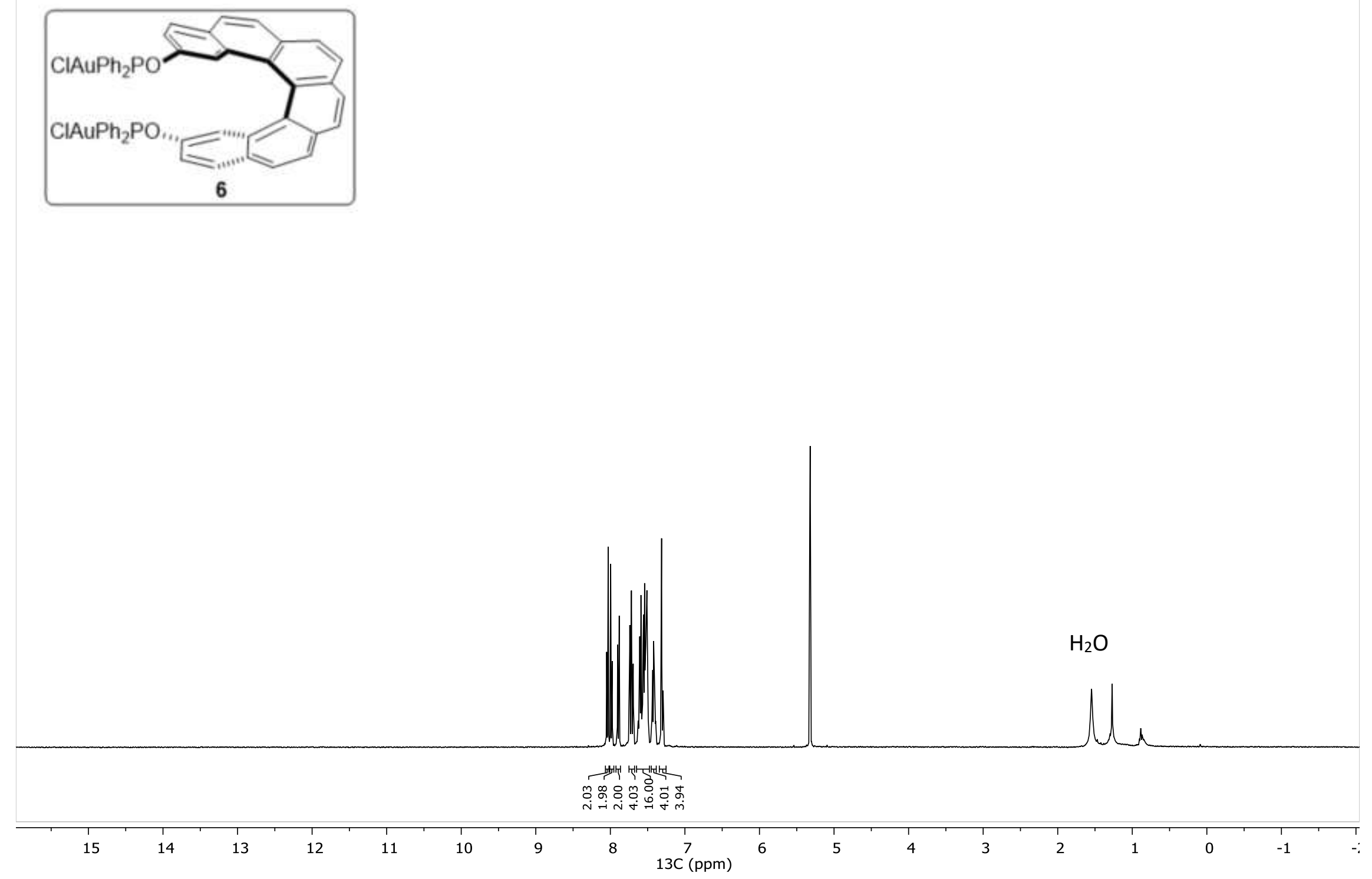


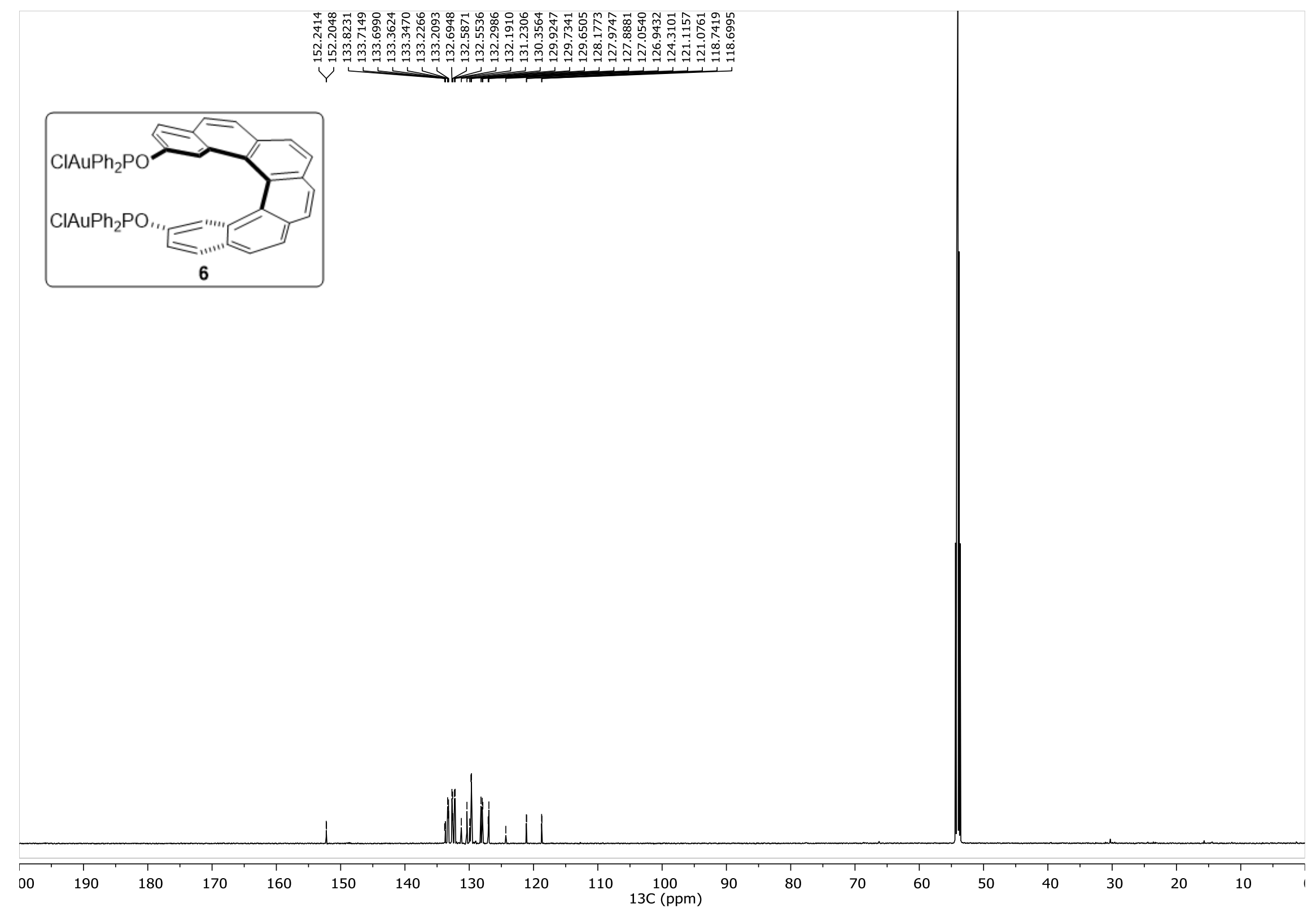




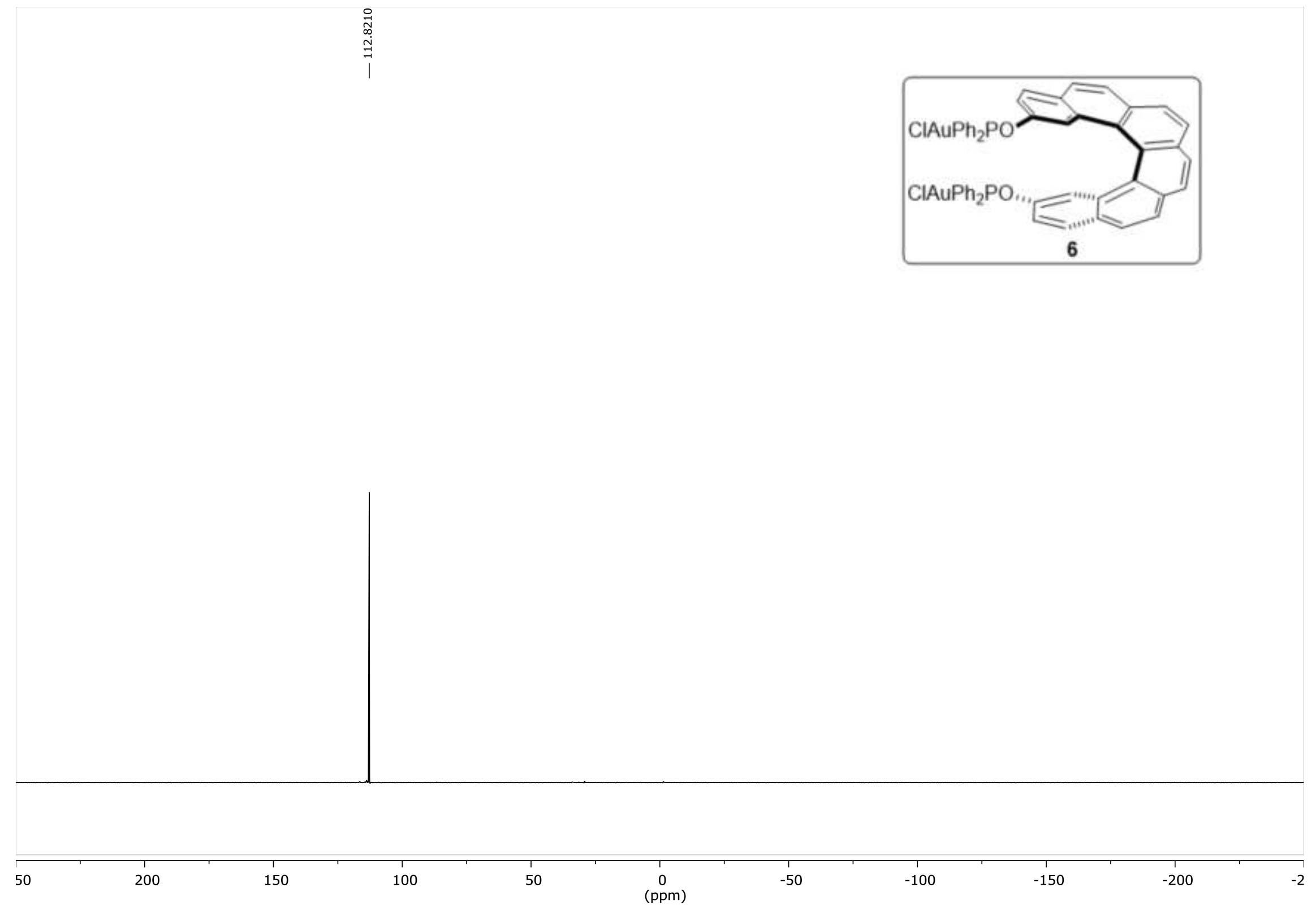




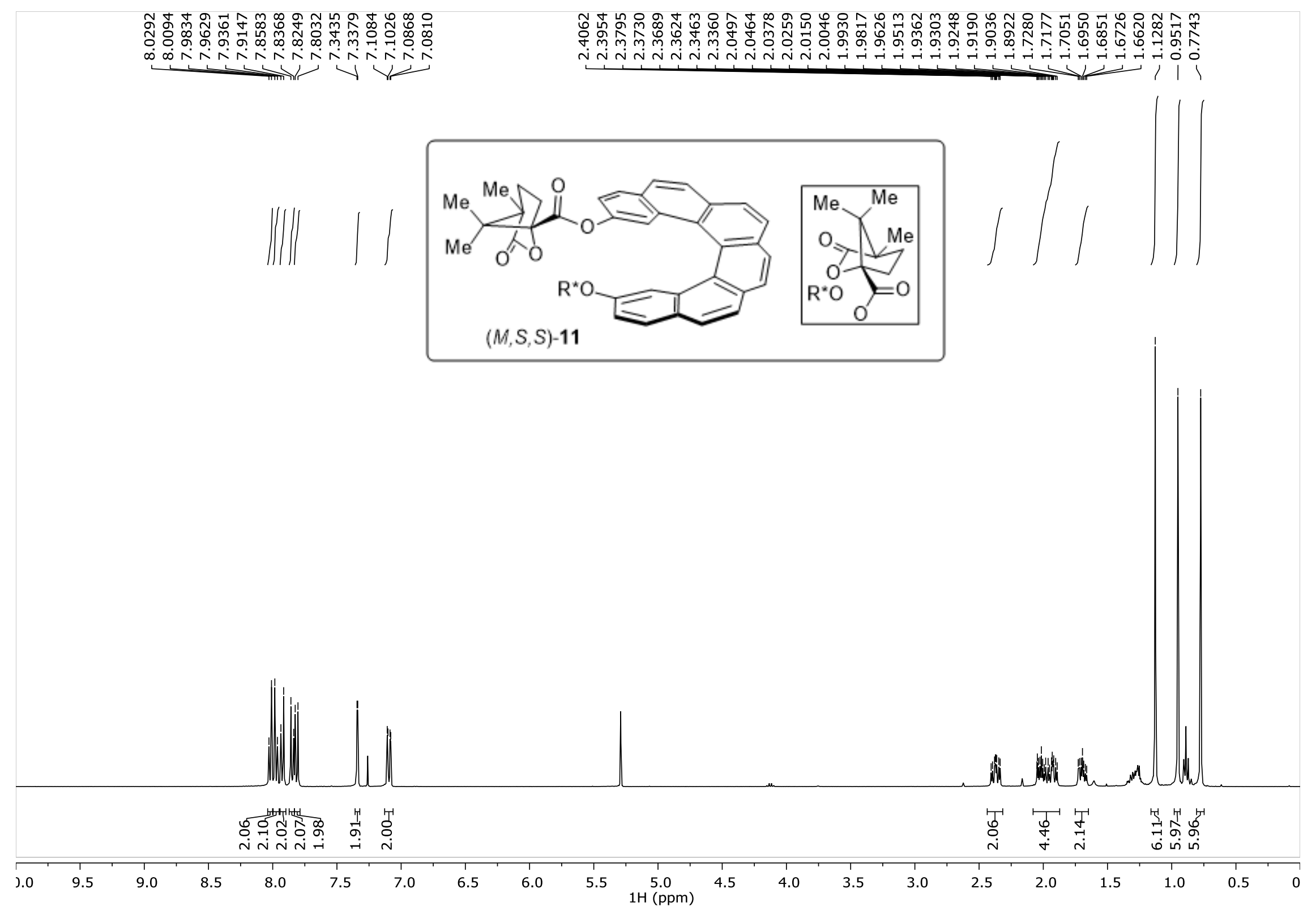




\begin{tabular}{|c|c|c|c|c|}
\hline \begin{tabular}{c}
$\hat{N}$ \\
\multirow{0}{0}{} \\
$\stackrel{0}{1}$ \\
1
\end{tabular} & 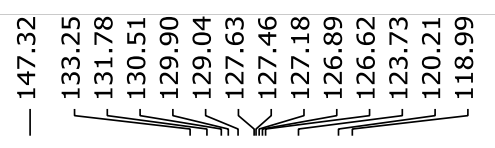 & 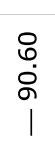 & 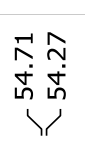 & 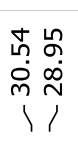 \\
\hline
\end{tabular}
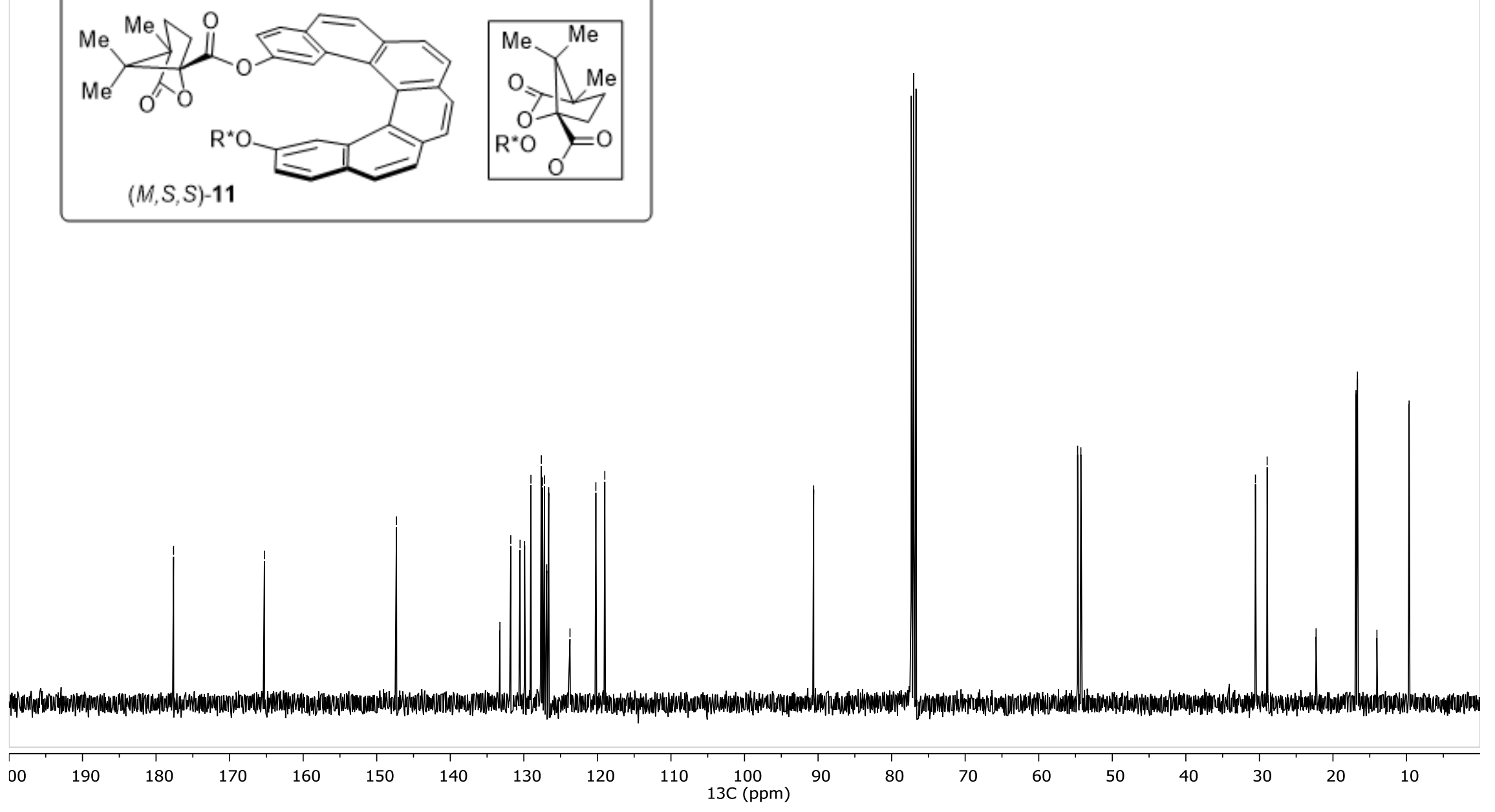


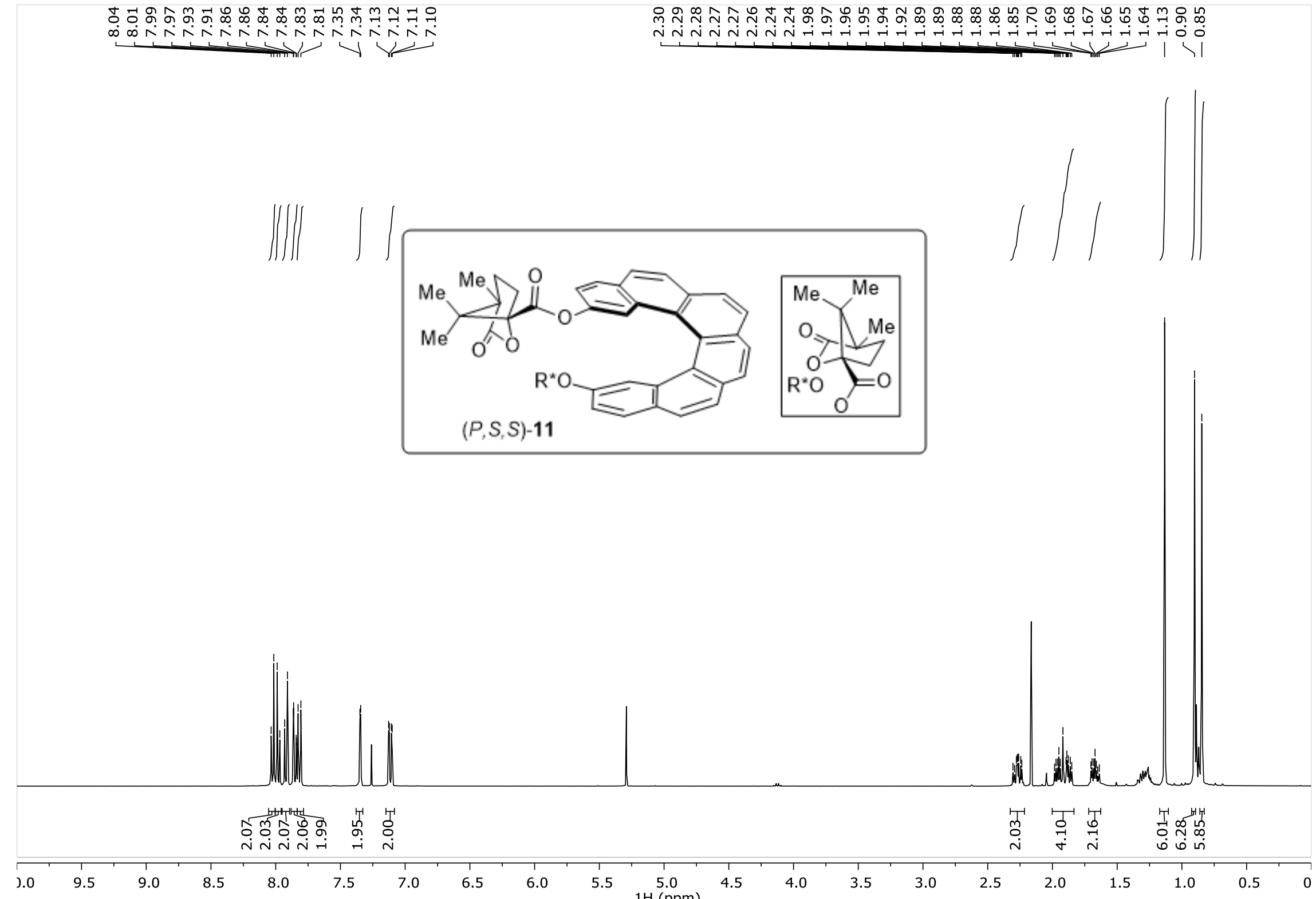




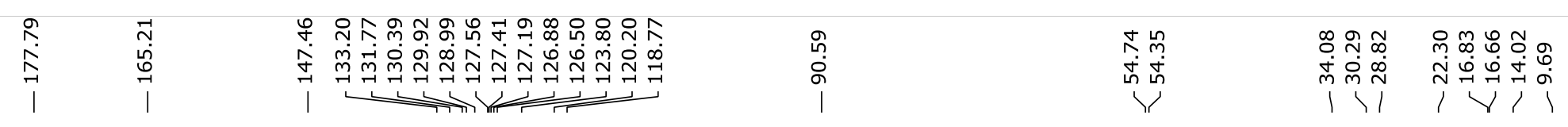
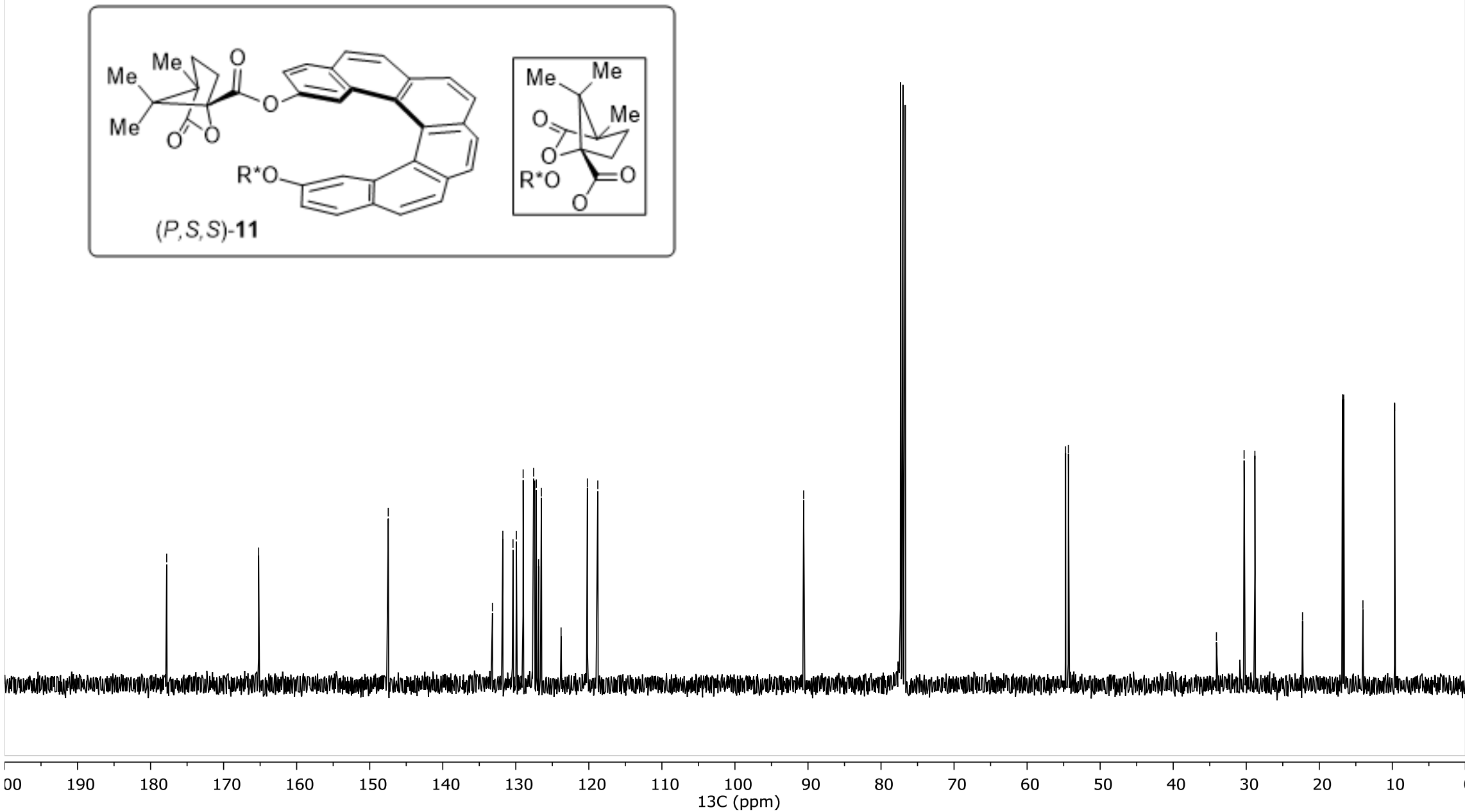


\section{Chiral HPLC analysis for $5=0$}

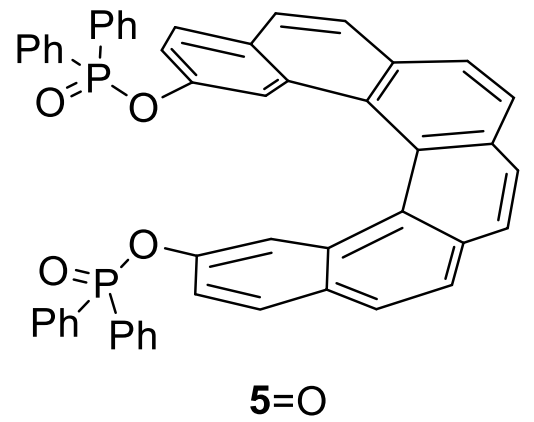

Conditions: Chiralpak IF $(250 \times 4.6 \mathrm{~mm}, 5$ microns), amylose tris(3-chloro-4methylphenylcarbamate) immobilized on silica, mobile phase : heptane / ethanol / dichloromethane (5/3/2), flow-rate $=1 \mathrm{~mL} / \mathrm{min}$, UV detection at $254 \mathrm{~nm}$ and polarimetric detection (Jasco OR-1590), Rt $(P)=7.2 \mathrm{~min}$, Rt $(M)=13.0 \mathrm{~min}, \mathrm{k}(P)=1.4, \mathrm{k}(M)=3.4$, enantioselectivity $\alpha=2.3$ and resolution $=11$.

\section{$\underline{\text { Rac-5=0: }}$}

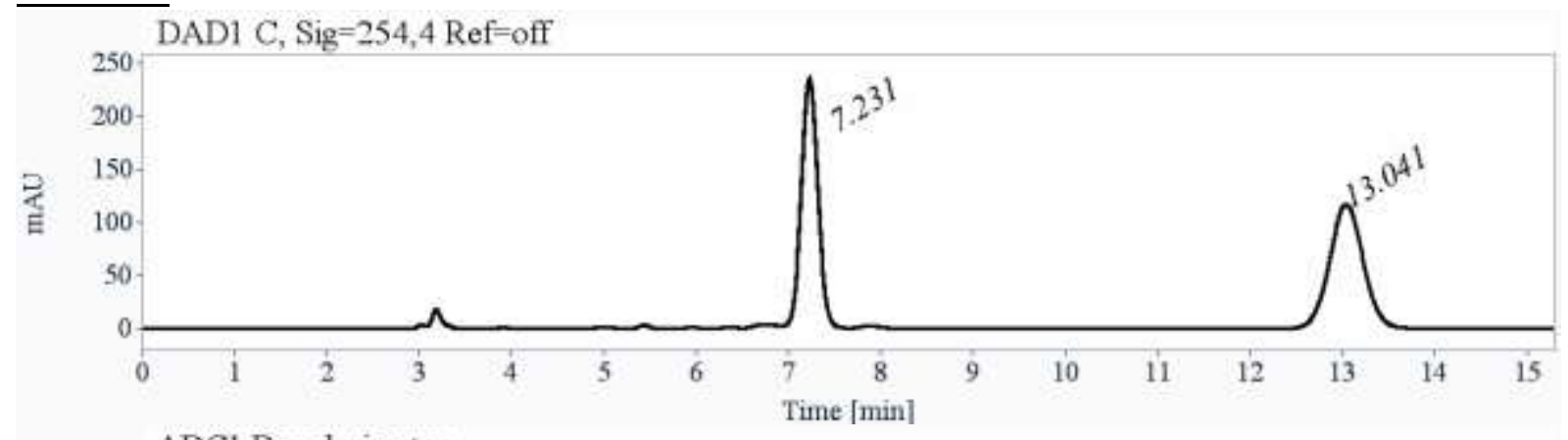

$\mathrm{ADCl} \mathrm{B}$, polarimeter

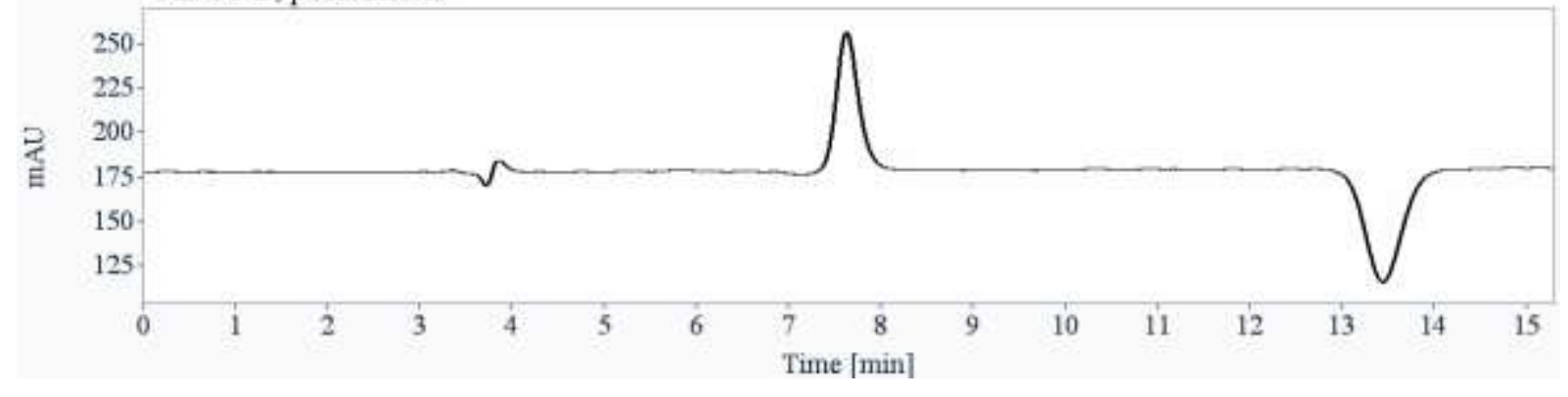

\begin{tabular}{|c|c|c|c|c|c|}
\hline RT [min] & Area & Area\% & Capacity Factor & Enantioselectivity & Resolution (USP) \\
\hline 7.23 & 2942 & 49.28 & 1.45 & & \\
\hline 13.04 & 3028 & 50.72 & 3.42 & 2.36 & 11.57 \\
\hline Sum & 5969 & 100.00 & & & \\
\hline
\end{tabular}


(P) $-5=0$ :

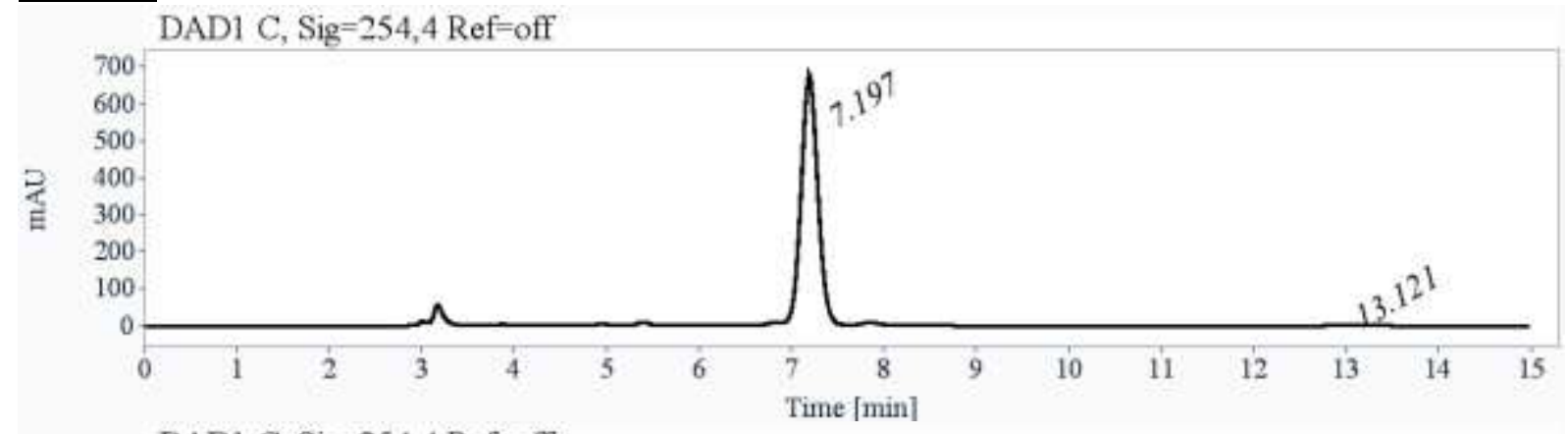

DAD1 C, Sig $=254,4$ Ref $=$ off

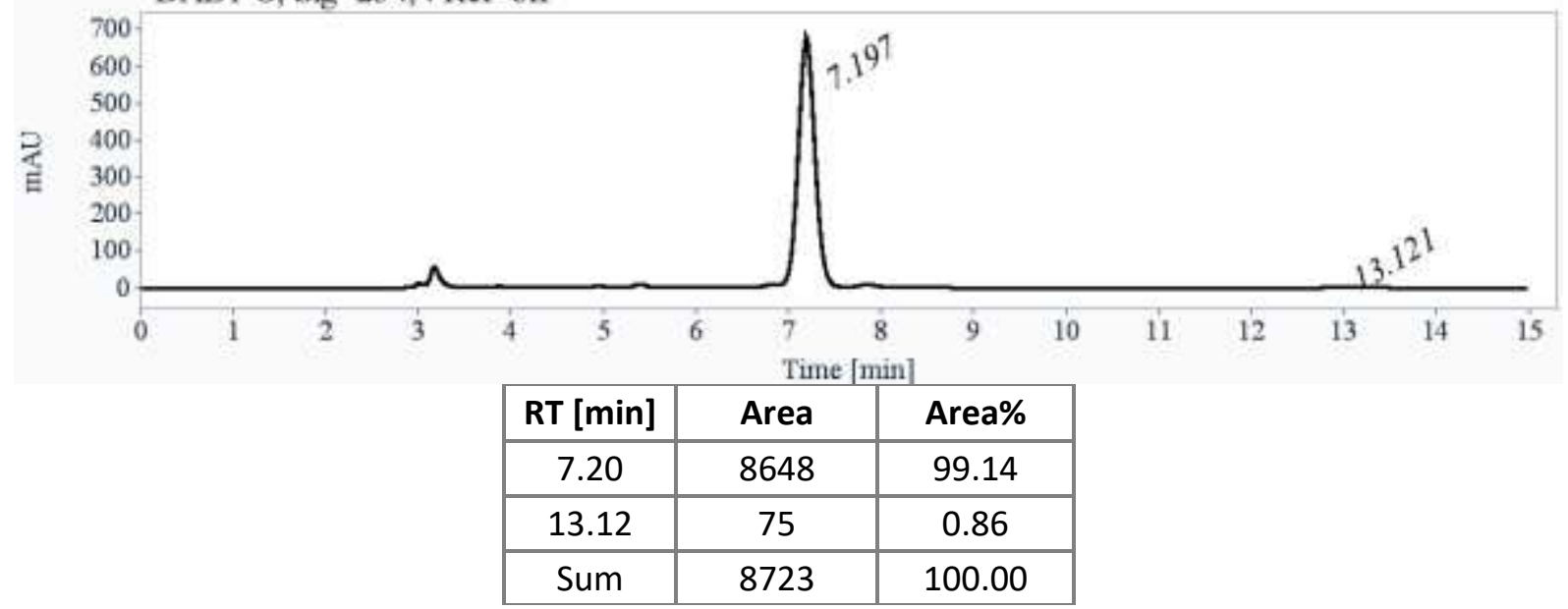

(M)-5=0:
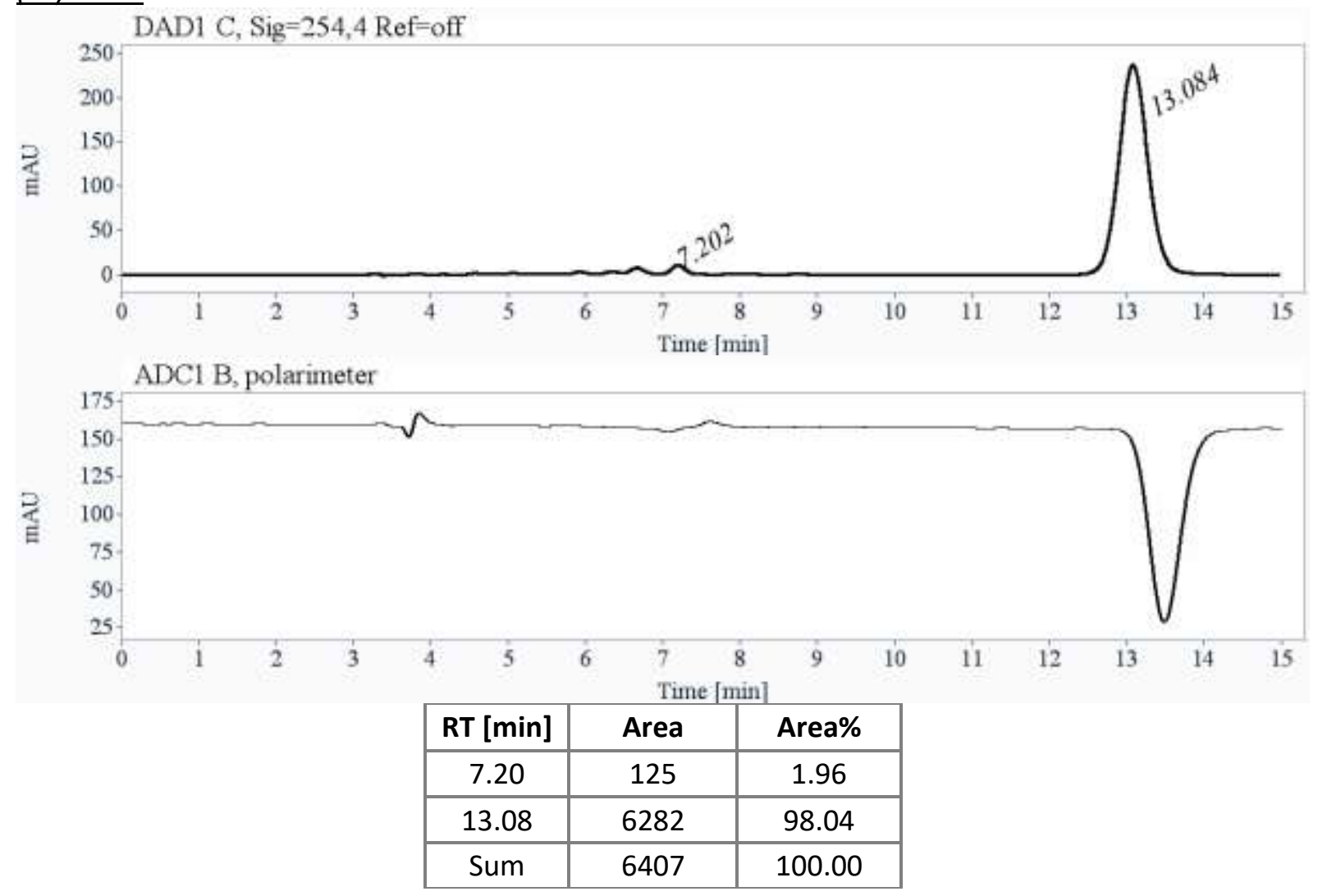


\section{ASYMMETRIC CATALYSIS}

\section{Chiral HPLC analysis for 9a}

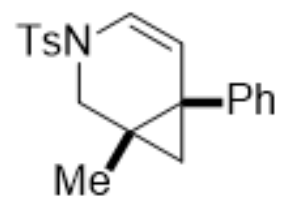

$9 a$

Two different analytical conditions were used to determine and confirm the low enantiomeric excesses.

\section{Conditions A:}

Chiralpak AS-H (250 $4.6 \mathrm{~mm}, 5$ microns), amylose tris[(S)alpha-phenethyl] carbamate coated on silica, mobile phase : heptane / 2-PrOH (95/5), flow-rate $=1 \mathrm{~mL} / \mathrm{min}$, UV detection at 220 $\mathrm{nm}$ and polarimetric detection (Jasco OR-1590), Rt $(R, R)=9.3 \mathrm{~min}, \mathrm{Rt}(S, S)=10.6 \mathrm{~min}, \mathrm{k}(R, R)$ $=2.2$, Rt $(S, S)=2.6$, enantioselectivity $\alpha=1.18$ and resolution $=1.6$.

\section{Conditions B:}

Lux-Cellulose-4 (250 x $4.6 \mathrm{~mm}, 3$ microns), Cellulose tris(4-chloro-3-methylphenylcarbamate) coated on silica, mobile phase : heptane / 2-PrOH (95/5), flow-rate $=1 \mathrm{~mL} / \mathrm{min}$, UV detection at $220 \mathrm{~nm}$ and polarimetric detection (Jasco OR-1590), Rt $(R, R)=14.0 \mathrm{~min}, \mathrm{Rt}(S, S)=16.6 \mathrm{~min}$, $\mathrm{k}(R, R)=3.8, \mathrm{Rt}(S, S)=4.7$, enantioselectivity $\alpha=1.23$ and resolution $=4.3$.

\section{Table 5, entry 1, Conditions A}

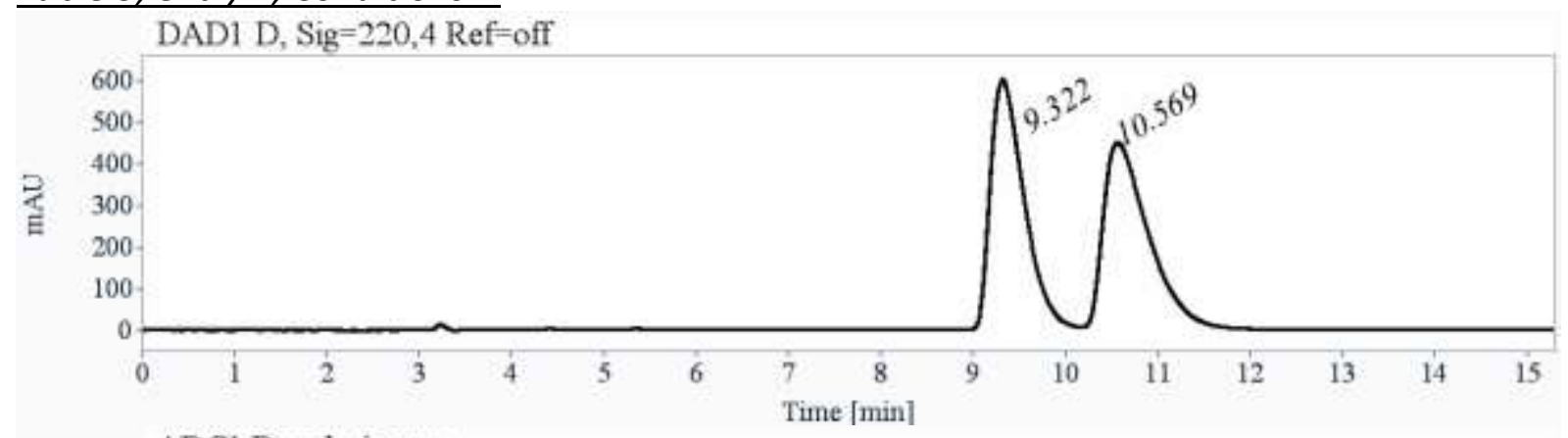

$\mathrm{ADCl} \mathrm{B}$, polarimeter

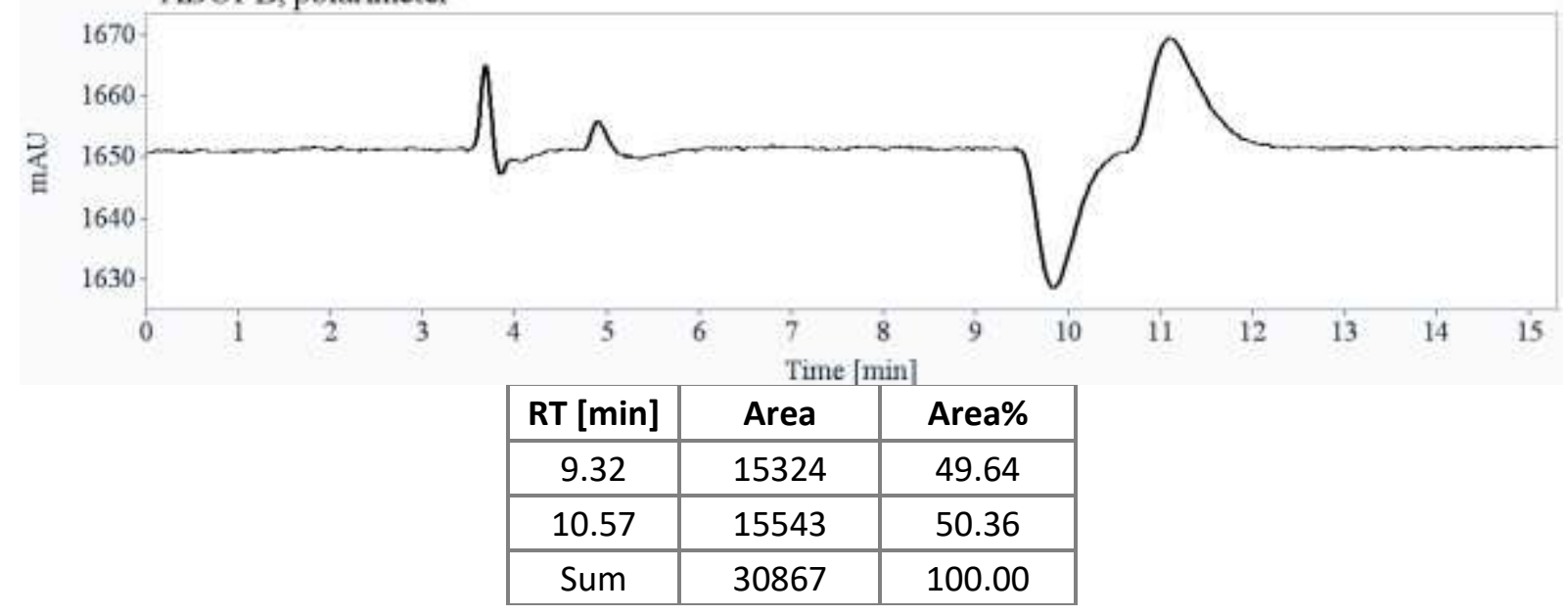


Table 5, entry 1 , Conditions $B$
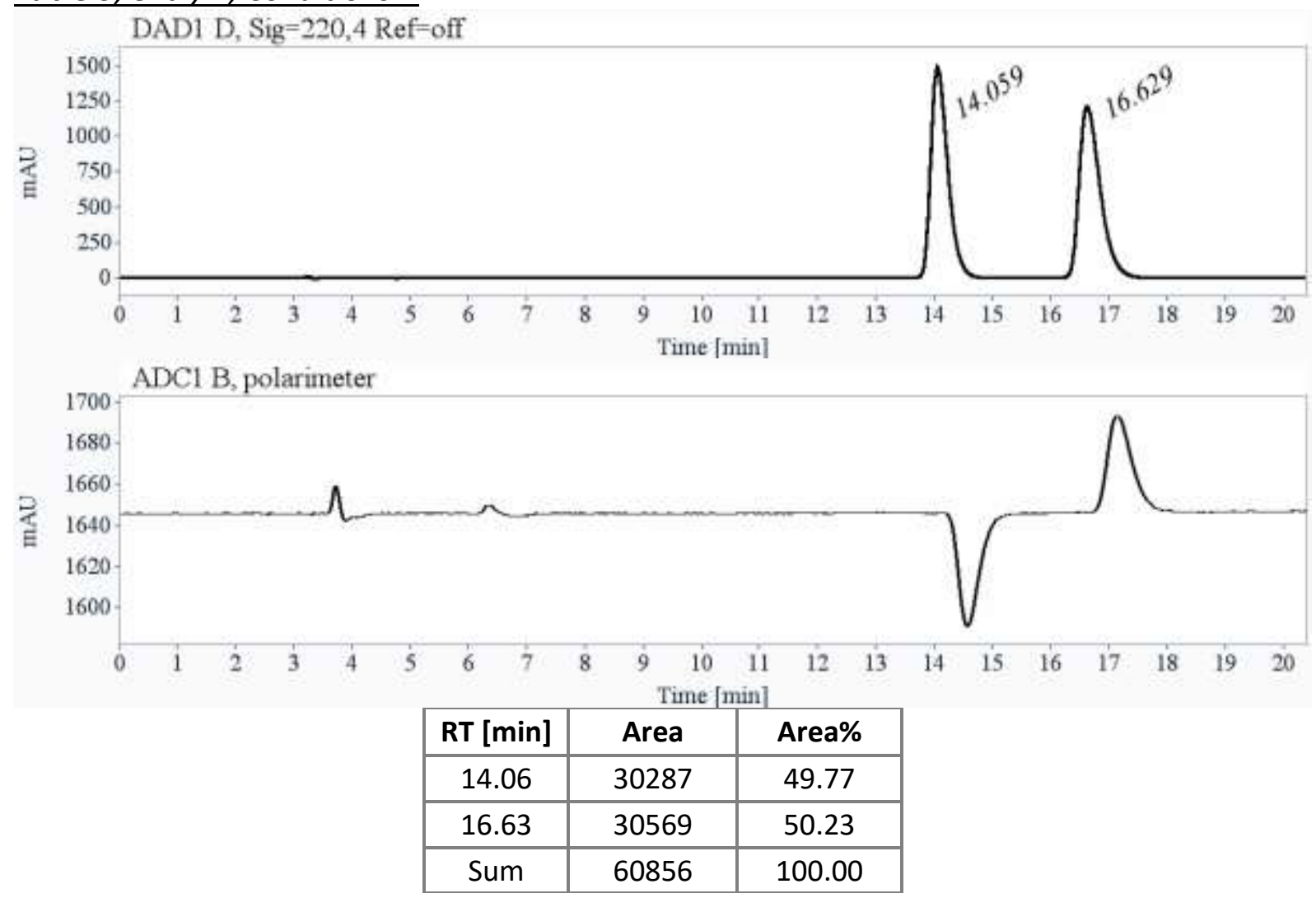

Table 5, entry 2, Conditions A
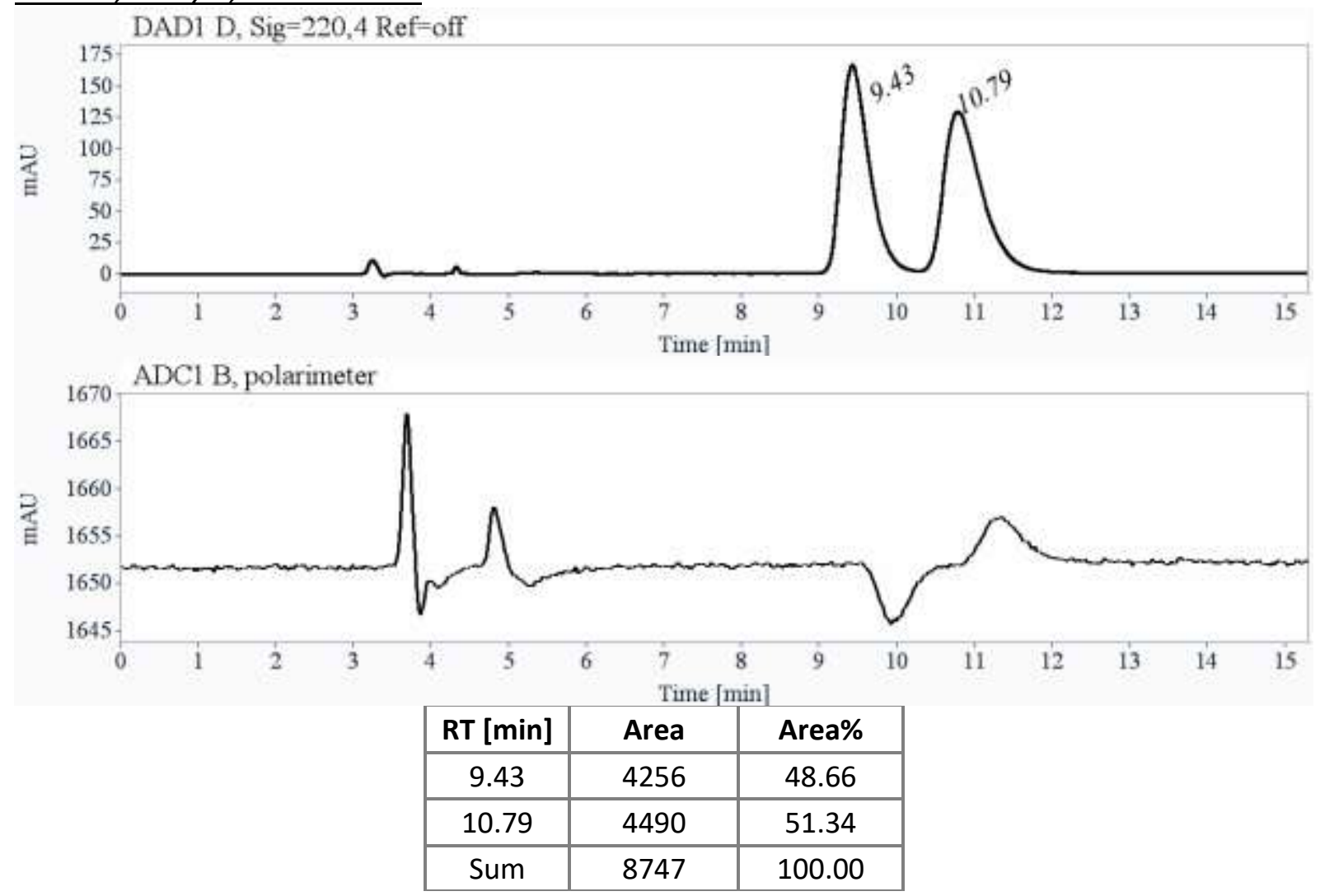
$\underline{\text { Table 5, entry 2, Conditions B }}$

DAD1 D, Sig $=220,4$ Ref $=$ off
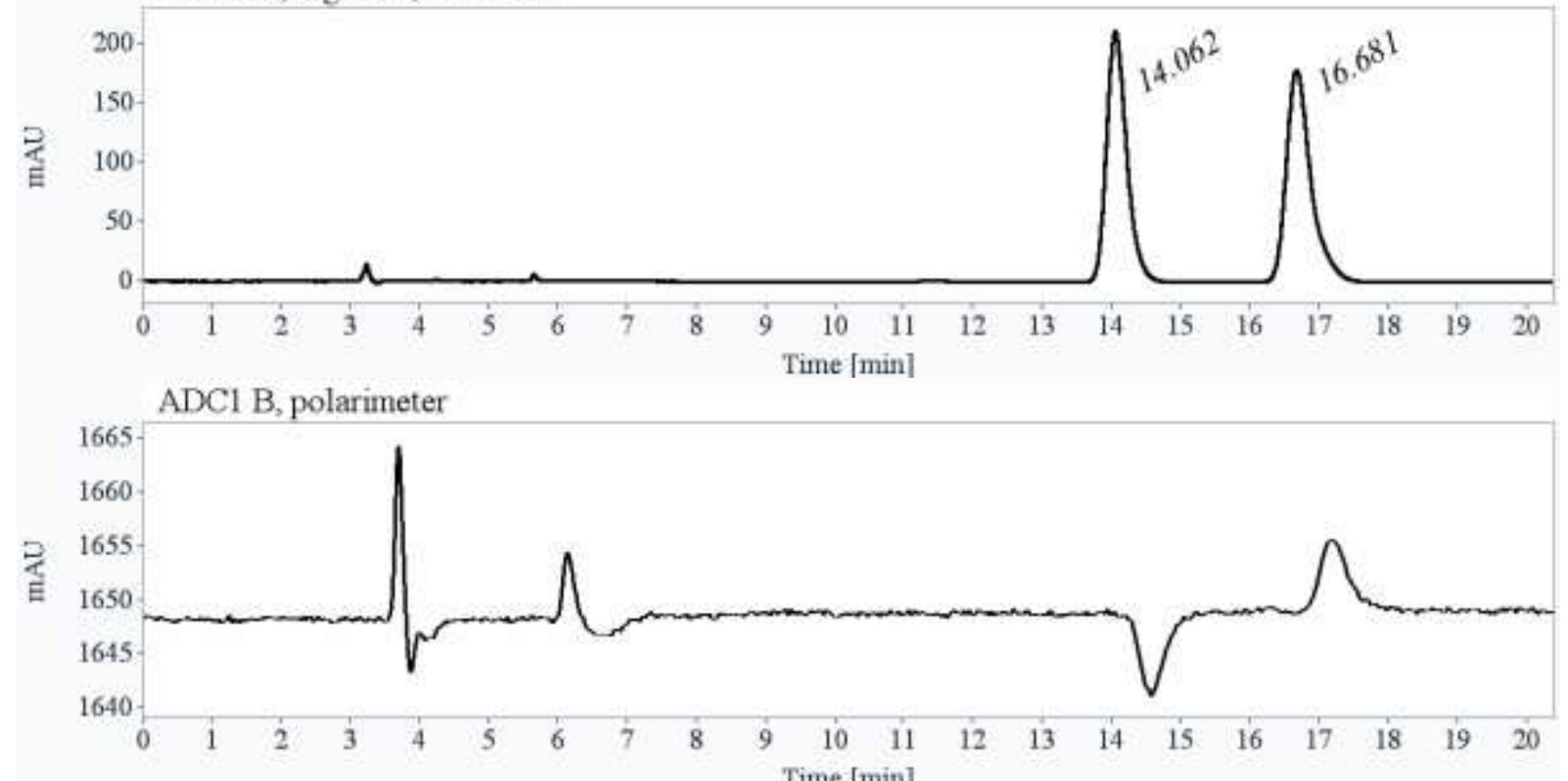

\begin{tabular}{|c|c|c|}
\hline RT [min] & Area & Area\% \\
\hline 14.06 & 4185 & 48.65 \\
\hline 16.68 & 4417 & 51.35 \\
\hline Sum & 8602 & 100.00 \\
\hline
\end{tabular}

Table 5, entry 3, Conditions A
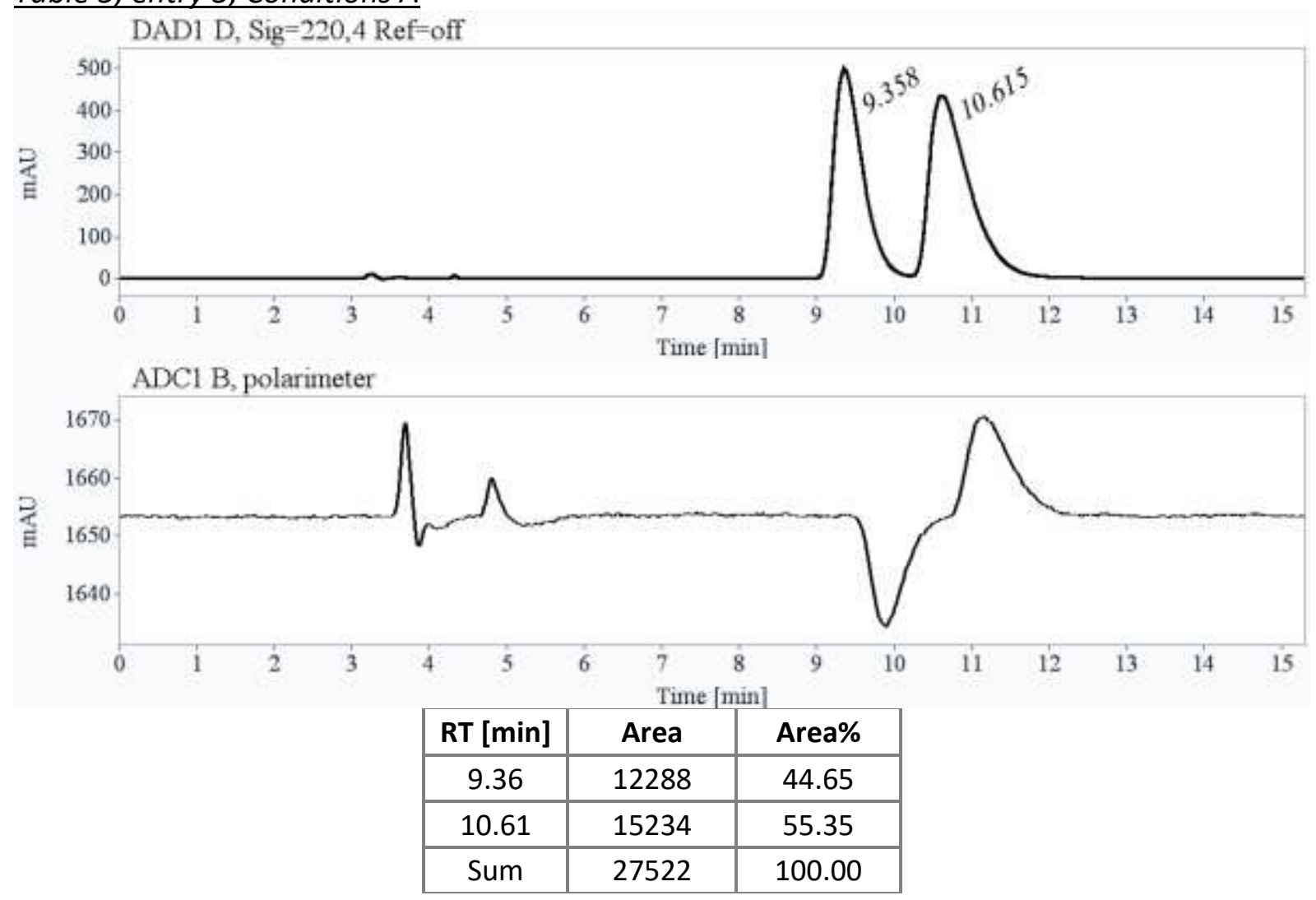
$\underline{\text { Table 5, entry 3, Conditions B }}$

DAD1 D, Sig=220,4 Ref=off

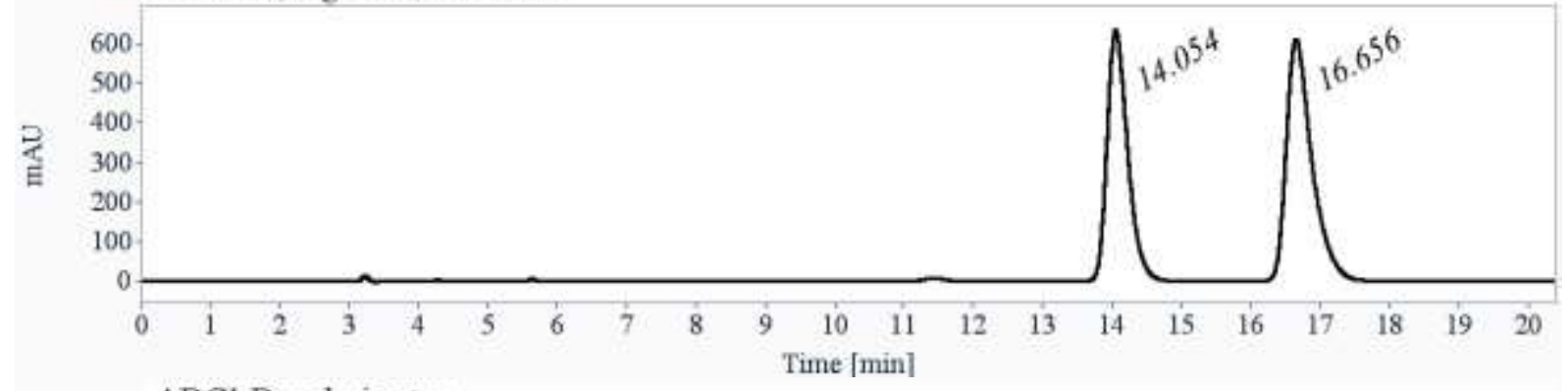

$\mathrm{ADCl} \mathrm{B}$, polarimeter

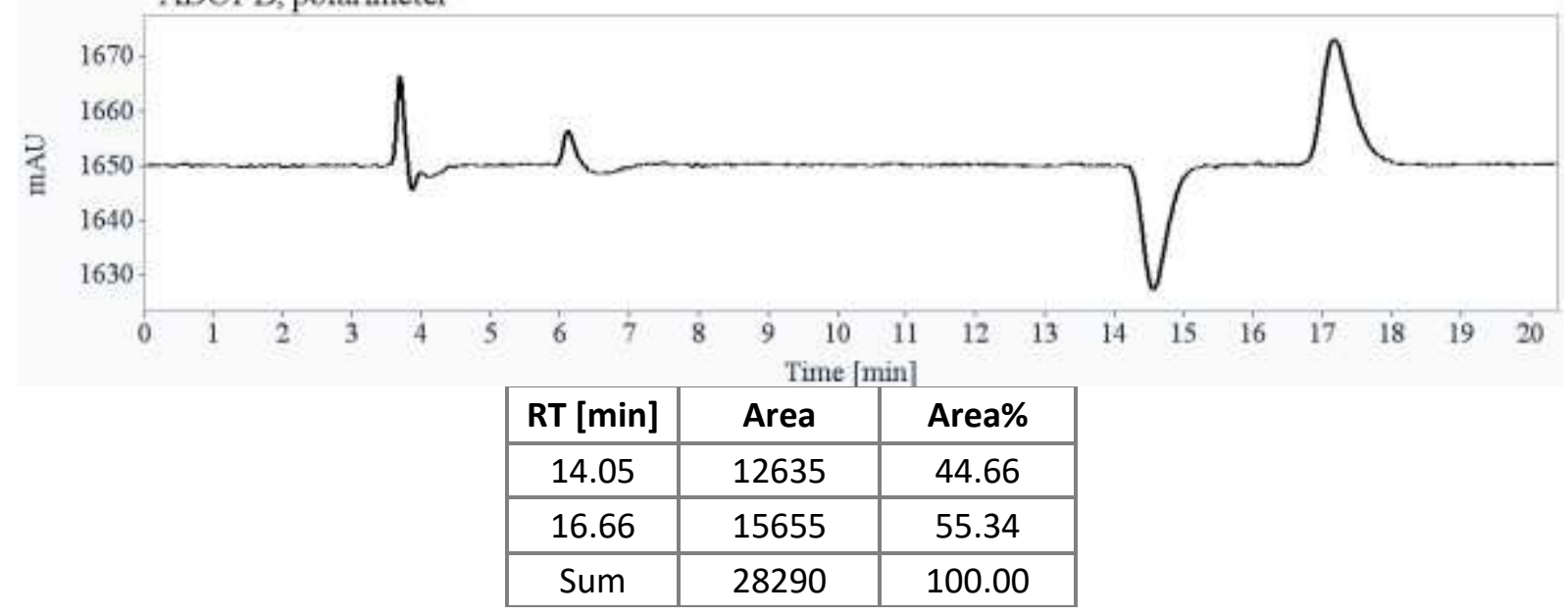

Chiral HPLC analysis for 12e

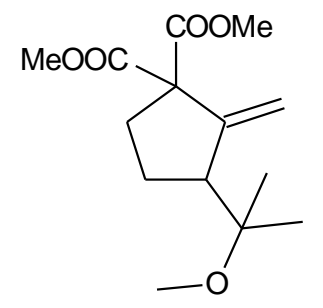

Two different analytical conditions were used to determine and confirm the low enantiomeric excesses.

Conditions A: Lux-Amylose-1 (250 x $4.6 \mathrm{~mm}, 5$ microns), amylose tris(3,5-dimethylphenylcarbamate) coated on silica, mobile phase : heptane / 2-PrOH (95/5), flow-rate $=1$ $\mathrm{mL} / \mathrm{min}$, UV detection at $220 \mathrm{~nm}$ and circular dichroism detection at $230 \mathrm{~nm}$ (Jasco CD-2095), $\operatorname{Rt}(S)=5.0 \mathrm{~min}, \operatorname{Rt}(R)=5.7 \mathrm{~min}, \mathrm{k}(S)=0.7, \mathrm{Rt}(R)=0.9$, enantioselectivity $\alpha=1.3$ and resolution $=4$.

Conditions B: Lux-Cellulose-4 $(250 \times 4.6 \mathrm{~mm}, 3$ microns), Cellulose tris(4-chloro-3methylphenylcarbamate) coated on silica, mobile phase : heptane / 2-PrOH (95/5), flow-rate $=1$ $\mathrm{mL} / \mathrm{min}$, UV detection at $220 \mathrm{~nm}$ and circular dichroism detection at $230 \mathrm{~nm}$ (Jasco CD-2095), $\operatorname{Rt}(S)=5.7 \mathrm{~min}, \mathrm{Rt}(R)=13.0 \mathrm{~min}, \mathrm{k}(S)=0.9$, Rt $(R)=3.4$, enantioselectivity $\alpha=3.7$ and resolution $=16$. 
Scheme 5, Conditions A

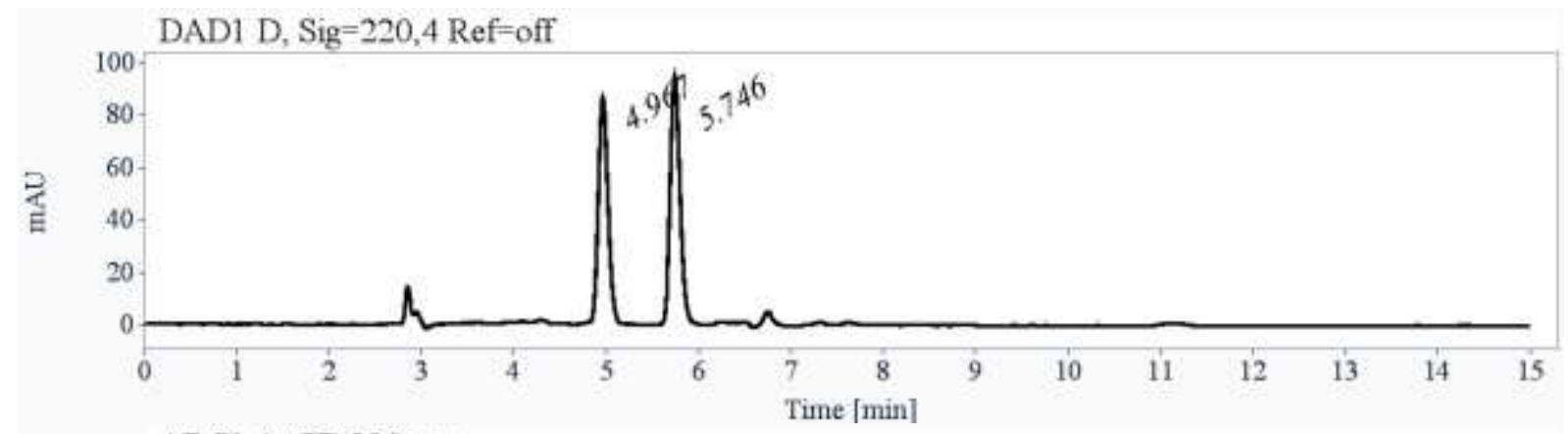

$\mathrm{ADCl} A, \mathrm{CD} 230 \mathrm{~nm}$

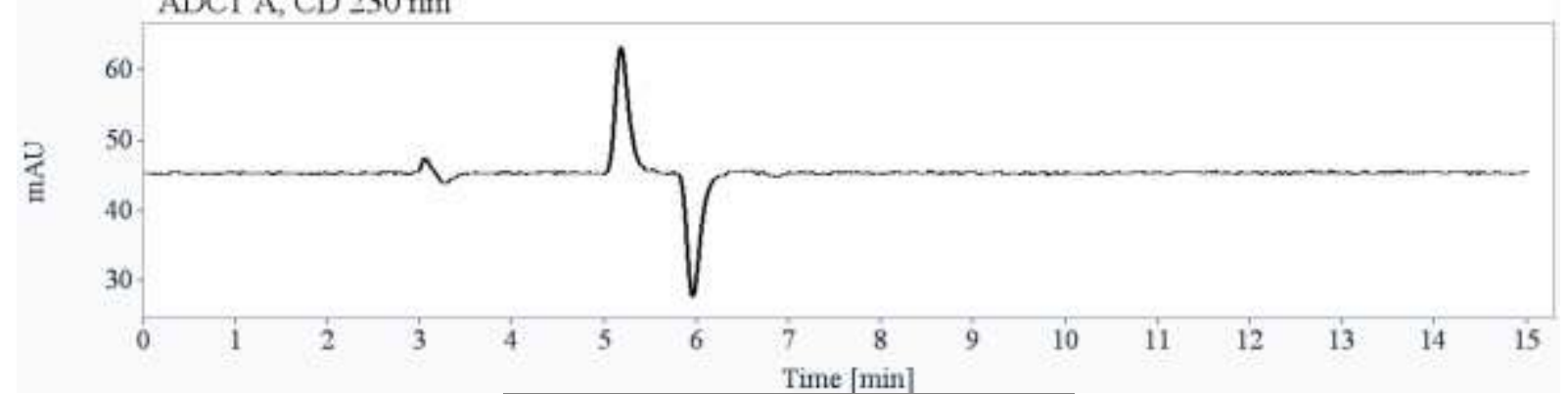

\begin{tabular}{|c|c|c|}
\hline RT [min] & Area & Area\% \\
\hline 4.97 & 626 & 47.47 \\
\hline 5.75 & 692 & 52.53 \\
\hline Sum & 1318 & 100.00 \\
\hline
\end{tabular}

\section{Scheme 5, Conditions B}
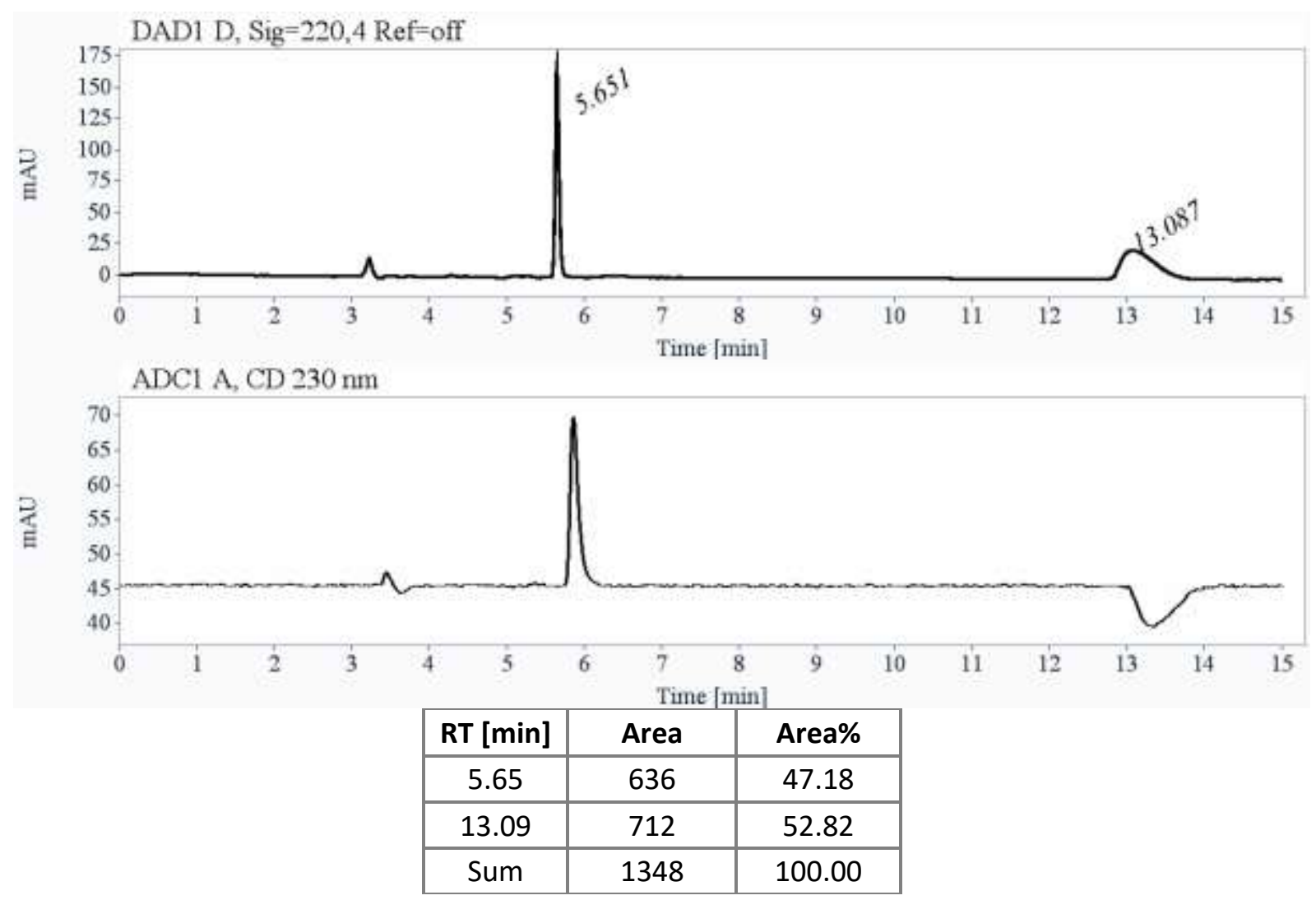
4. CYCLOISOMERIZATION SPECTRA

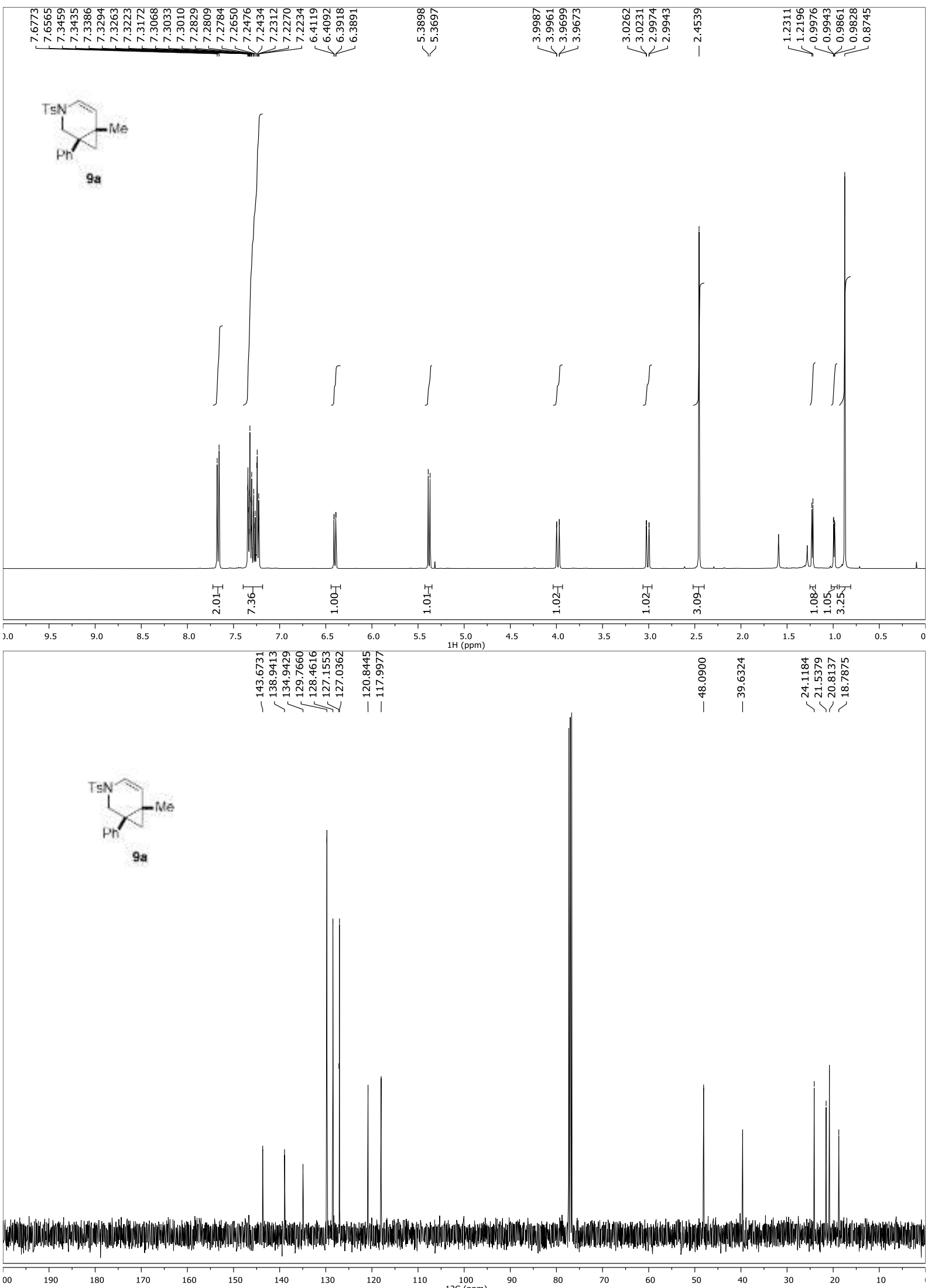


<smiles>CC1(C)CN([S+]([O-])([O-])c2ccccc2)C=CC1[N+](=O)[O-]</smiles>
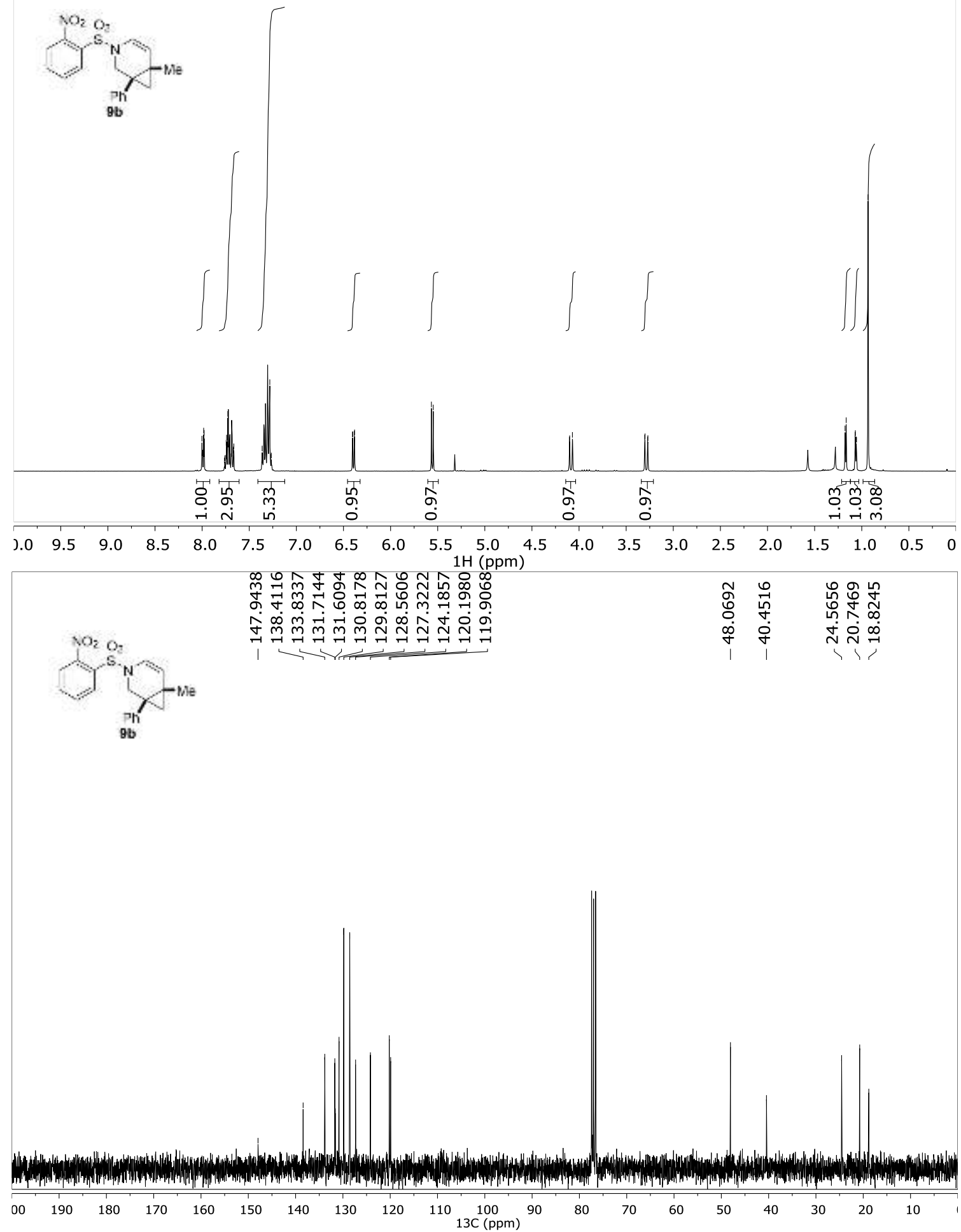


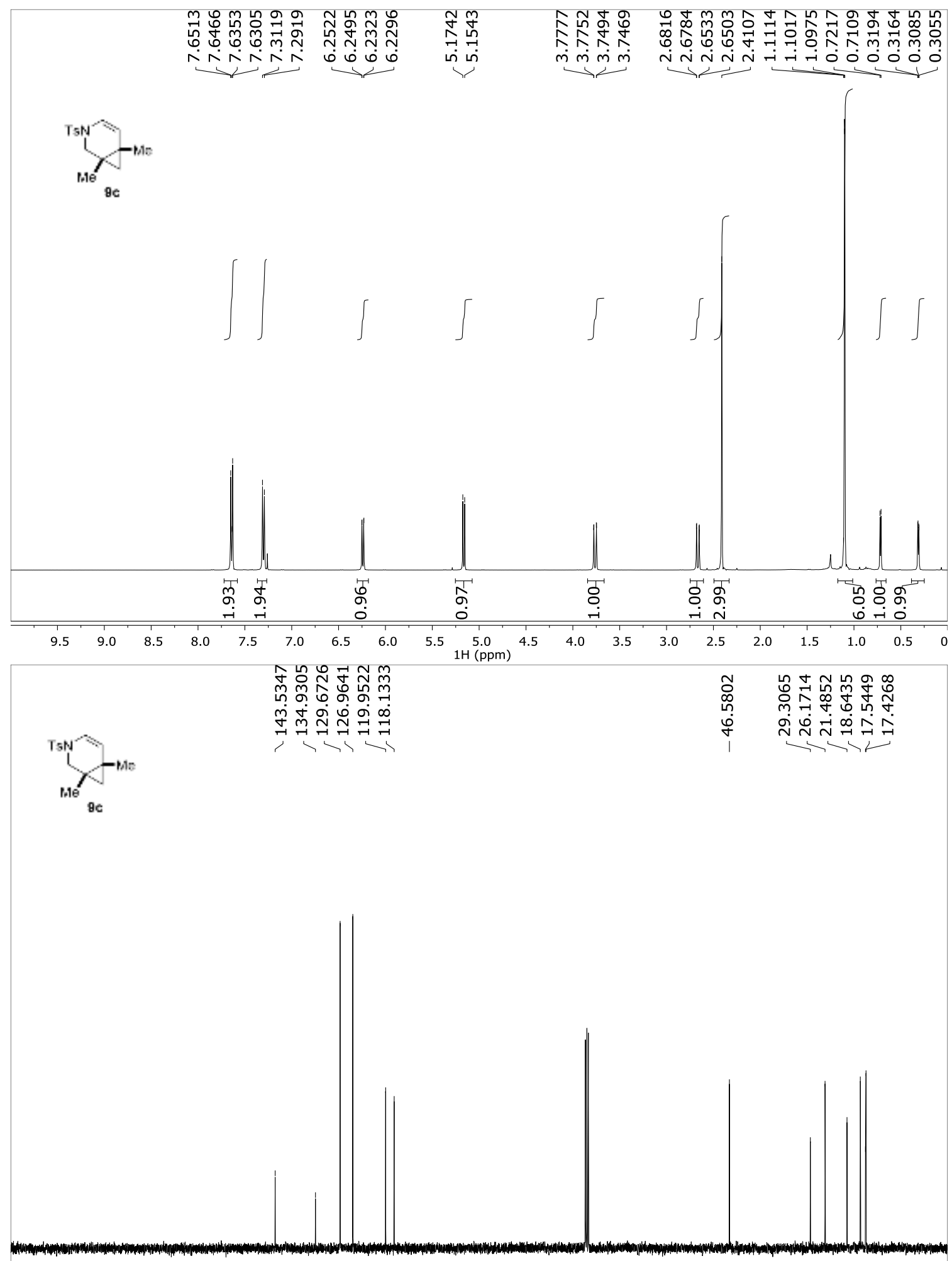

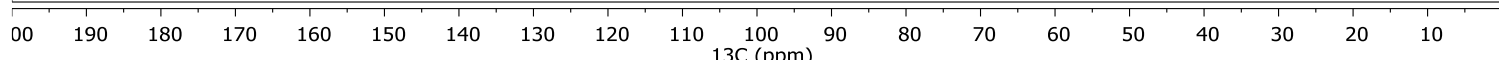




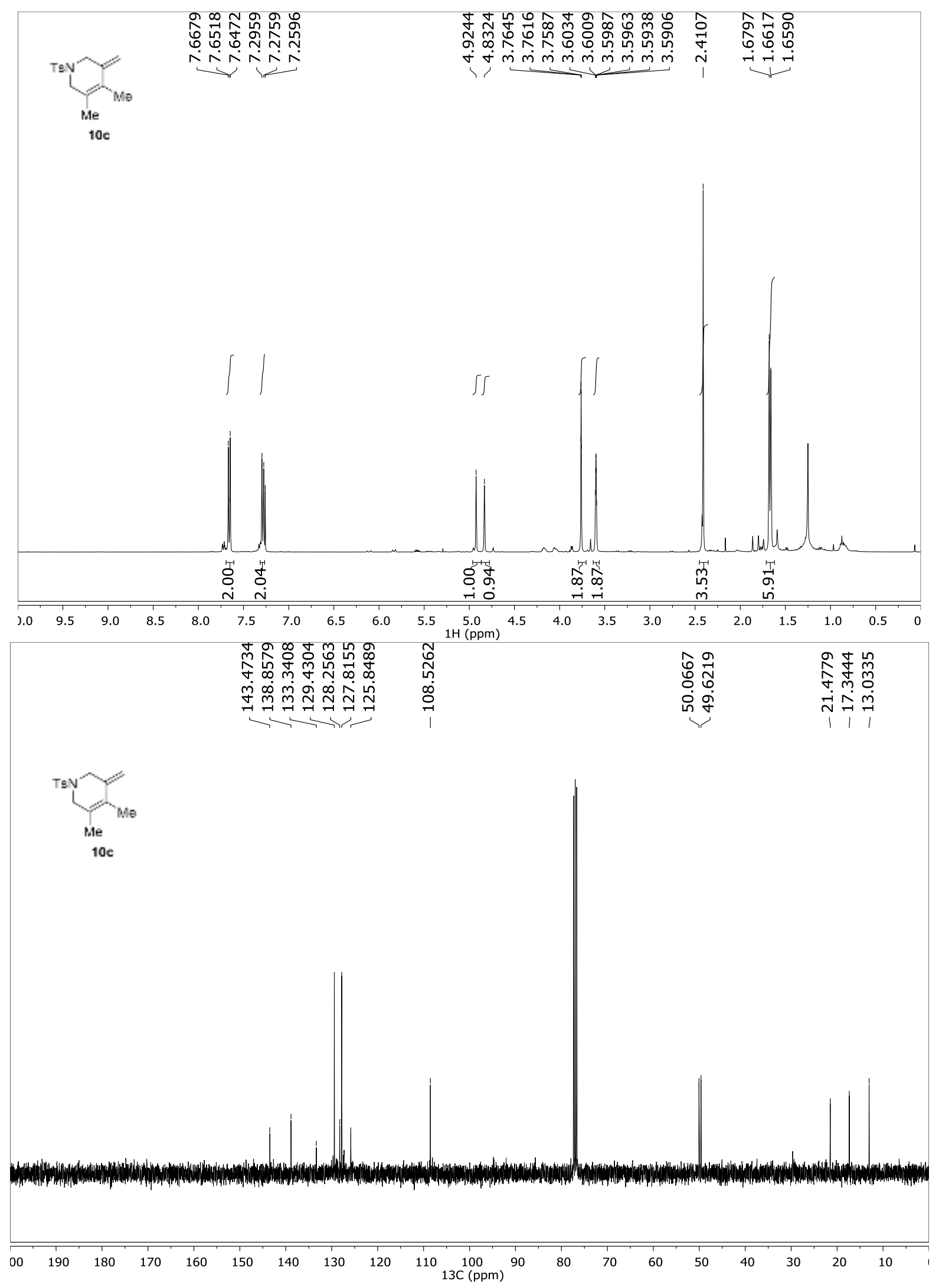



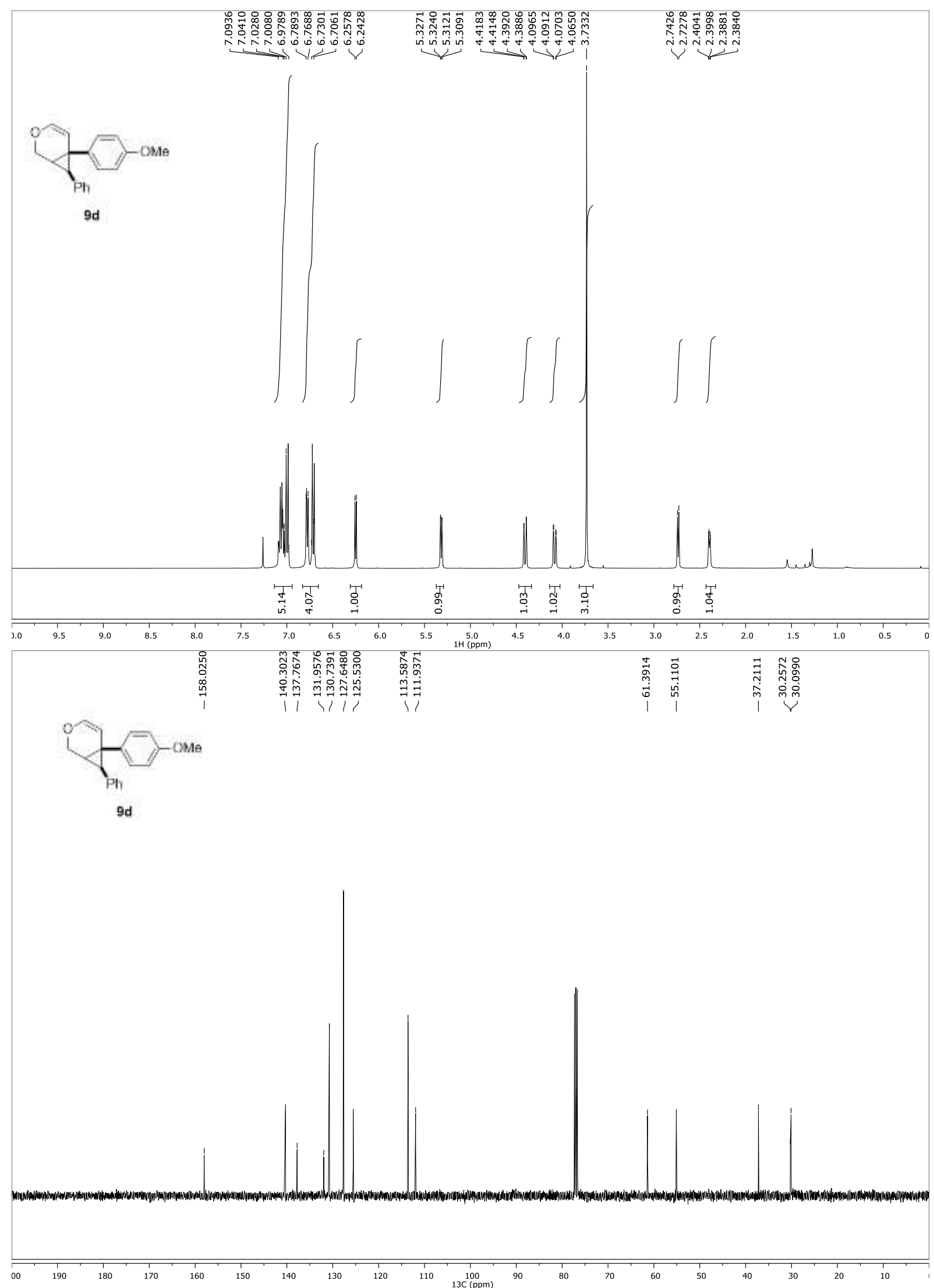

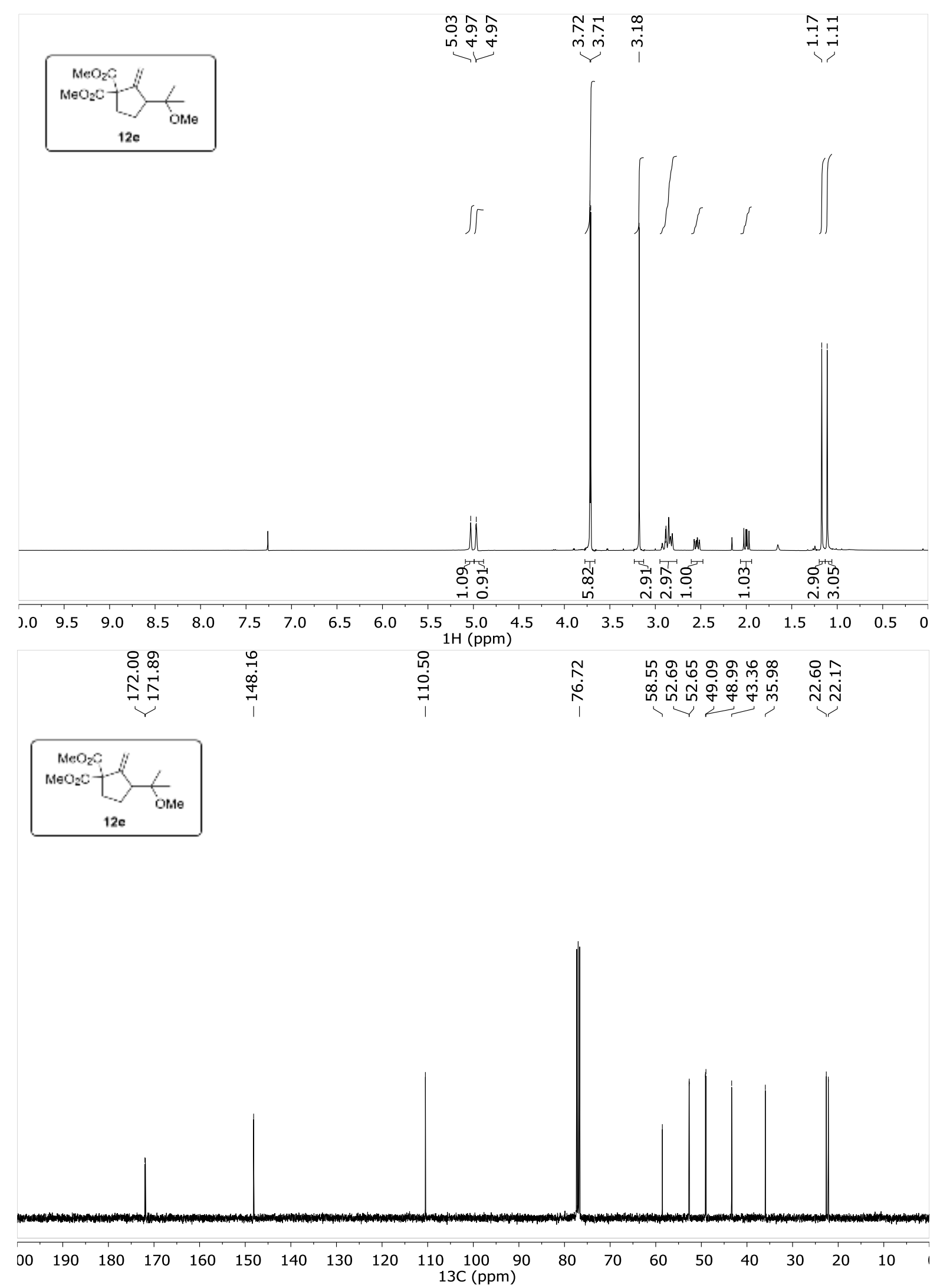